\title{
DZIEJE FUNDACJI KSIECCIA ALEKSANDRA LUBOMIRSKIEGO W KRAKOWIE (ul. Rakowicka 27) W LATACH 1893-1950
}

\section{WYKAZ SKRóTóW}
AH - Acta Hlondiana. Materiały do życia i działalności kard. Augusta Hlonda Prymasa Polski 1881-1948, t. 6, cz. 14, zebrał ks. S. Kosiń- ski, Ląd n. Wartą 1973, mps.
ArITSK - Archiwum Inspektorialne Towarzystwa Salezjańskiego w Krakowie AKMKr - Archiwum Kurii Metropolitalnej w Krakowie
ASC - Archiwum Generalne Towarzystwa Świętego Franciszka Salezego w Rzymie
ASMK - Archiwum Sióstr Miłosierdzia
ArZSO - Archiwum Zakładu Salezjańskiego w Oświęcimiu
b.s.
- bez sygnatury
BWS - Byli Wychowankowie Salezjańscy (związek)
c.k. - cesarsko-królewski
„Echo Bursy”- „Echo Salezjańskiej Bursy fund. Ks. Al. Lubomirskiego”
koad. - koadiutor
PS - „Pokłosie Salezjańskie”
PSB - Polski Słownik Biograficzny
s. $\quad-$ siostra
T. $\quad-$ teczka
WS - „Wiadomości Salezjańskie”
WKL - Wojewódzka Komisja Lokalowa

\section{WSTĘP}

W XIX w. przeludniona wieś galicyjska nie mogła wyżywić wszystkich swoich mieszkańców. W nadziei na lepsze życie wielu $z$ nich udawało się do miast, powiększając w ten sposób szeregi biedoty miejskiej, wśród której los dzieci i młodzieży był równie godny pożałowania. Problemem młodzieży ubogiej i opuszczonej zajmowały się zarówno różnorodne instytucje charytatywne, 
jak i osoby prywatne. Do tych, którym los młodzieży nie był obojętny i którzy starali się przyjść jej z wydatną pomocą, należał książę Jerzy Aleksander Lubomirski. $Z$ jego inicjatywy i wydatnej pomocy materialnej powstało w 1893 r. schronisko dla opuszczonej młodzieży Krakowa. Nazwa „schronisko” i jej synonimy: „bursa”, „zakład” określa dom młodzieży oraz personel i wychowanków.

Przedmiotem niniejszej pracy są dzieje schroniska im. Aleksandra Lubomirskiego od jego powstania do chwili zamknięcia go przez władze Polskiej Rzeczypospolitej Ludowej w 1950 r. Autor pragnie uzyskać odpowiedź na pytanie: czy schronisko spełniło oczekiwanie fundatora i jakie były owoce jego, ponad pięćdziesięcioletniej, działalności.

Dziejom i działalności schroniska nie poświęcono dotychczas osobnego opracowania. Fragmentaryczne wiadomości na ten temat znajdują się w pracach omawiających działalność charytatywną na terenie Krakowa. Obszerniejsze informacje na temat schroniska, zwłaszcza $z$ okresu kiedy przejęli je salezjanie (1911-1950), zawiera jedynie praca ks. Jana Ślósarczyka SDB zatytułowana: Historia Prowincji Św. Jacka Towarzystwa Salezjańskiego w Polsce, Pogrzebień 1960-1968. Z tego względu podstawą niniejszej pracy stały się przede wszystkim materiały archiwalne.

Wiadomości o pierwszych latach funkcjonowania schroniska zaczerpnięto z niezbyt licznych materiałów, znajdujących się w Archiwum Sióstr Miłosierdzia w Krakowie. Archiwum Kurii Metropolitalnej w Krakowie dostarczyło fragmentarycznych informacji o długoletnich pertraktacjach (1904-1911) między ızw. kuratorią schroniska, a salezjanami, w których pośredniczyła krakowska kuria biskupia.

Najwięcej danych uzyskano ze zbiorów, znajdujących się w Archiwum Towarzysiwa Salezjańskiego w Krakowie. Zasób tego archiwum zawiera bogate materiały, dotyczące poszczególnych szkół, istniejących w schronisku, m.in. akta personalne wychowanków, roczne sprawozdania wizytacyjne, księgi i sprawozdania finansowe, dzienniki lekcyjne, wykazy personelu nauczającego, tygodniowe rozklady zajęć oraz akta dotyczące pertraktacji władz państwowych z salezjanami w sprawie podjęcia pracy w schronisku, akt fundacyjny schroniska i akta likwidacji zakładu w $1950 \mathrm{r}$.

Z przyczyn od autora niezależnych nie przeprowadzono kwerendy w Wojewódzkim Archiwum Państwowym w Krakowie.

Cennym uzupełnieniem materiałów archiwalnych okazały się dane zawarte w ówczesnej prasie, a zwłaszcza w biuletynie schroniska „Echo Bursy Salezjańskiej fund. Ks. Al. Lubomirskiego” (1926-1930) oraz w „Pokłosiu Salezjańskim" (1916-1949).

Opracowanie składa się $\mathrm{z}$ czterech rozdziałów ułożonych rzeczowo i chronologicznie. W rozdziale pierwszym przedstawiono genezę, powstanie schroniska i jego funkcjonowanie w latach I i II wojny światowej oraz 
likwidację w 1950 r. Następny rozdział zawiera omówienie struktury zarządu schroniska oraz przedstawia kuratorię, która była organem nadzorującym działalność schroniska ze strony władz państwowych. W rozdziale trzecim omówiono majątek fundacyjny i inne źródła utrzymania schroniska, jak: dotacje władz miejskich, opłaty uczniów, dochody z ogrodu, pensje salezjanów, zapomogi otrzymywane od prowincjała salezjanów i dochody z imprez artystycznych, organizowanych przez wychowanków. Natomiast w ostatnim rozdziale ukazano formy działalności pedagogiczno-dydaktycznej, stosowane w schronisku przed i po przejęciu go przez Towarzystwo Św. Franciszka Salezego.

\section{ROZDZIAE I \\ GENEZA, POWSTANIE I LOSY SCHRONISKA}

\section{Sytuacja w dziedzinie opieki $i$ wychowania młodzieży w Krakowie w XIX w.}

Trzy mocarstwa: Rosja, Prusy i Austria, likwidując ostatecznie państwo polskie 24 października 1795 r., liczyły na szybką i pełną asymilację zien zagarniętych jako integralnej części swych terytoriów. Wprowadziły obowiązujące u nich prawa i system administracyjny, usunęły polską szlachtę z wpływowych stanowisk państwowych, podniosły podatki i podjęły politykę germanizacji i rusyfikacji administracji i szkolnictwa ${ }^{1}$.

W styczniu 1796 r. Kraków stał się centrum terenów zagarniętych przez Austrię, które nazwano Galicją Zachodnią. Władze samorządowe zostały zniesione. Najwyższą władzą było Gubernium, z siedzibą dla Galicji Zachodniej i Wschodniej we Lwowie. Pod jego kompetencje od 1802 r. podlegały władze miejskie Krakowa, tj. nowy magistrat, pochodzący z nominacji. Magistrat zajmował się sprawami ekonomicznymi miasta i sądownictwem cywilnym, natomiast sprawy bezpieczeństwa, porządku i sprawy sanitarne, ponadto wszelkie widowiska, teatry, czuwanie nad włóczęgami, chorymi przeszły pod kompetencje nowo powstałej Dyrekcji Policji, sprawującej swą władzę tylko w granicach Krakowa ${ }^{2}$.

${ }^{1}$ Historia Polski, t. 1: 1784-1864, cz. 2: 1795-1831, red. A. Kieniewicz, W. Kula, Warszawa 1958, s. 32; Oświata i szkolnictwo w Rzeczypospolitej Polskiej, Warszawa 1929, s. 15-21; J. B i eniarzowna, J. Małecki, Dzieje ziemi krakowskiej w wypisach, Warszawa 1956, s. 149; E. Kurdy ba ch a, Historia wychowania, t. 2, Warszawa 1967, s. 104.

2 D. R e de row a, Kraków porozbiorowy, w: Kraków, jego dzieje i sztuka, red. J. Dąbrowski, Warszawa 1956, s. 397. 
Kraków z końca XVIII w. był miastem pozbawionym urządzeń charakterystycznych dla ośrodka nowoczesnego, o siatce ulic nie zmienionej od czasów lokacji, tj. od XIII w., ciasno zabudowany, źle oświetlony, częściowo tylko wybrukowany, bez urządzeń kanalizacyjnych. Na przedmieściach stały nędzne chatki i karczmy ${ }^{3}$. Austriacy rozpatrywali możliwości podźwignięcia gospodarczego Krakowa. Wyczerpanie wojnami napoleońskimi monarchii austriackiej $\mathrm{z}$ jednej i słaby stan finansowy miasta $\mathrm{z}$ drugiej strony, przeszkodziły temu. Projekty rozwoju miasta „ograniczały się do urządzeń, które powstrzymywały rosnące zło" 4 .

W 1809 r. doszło do nowej wojny między Austrią a Napoleonem. Armia Księstwa Warszawskiego, pod wodzą księcia Józefa Poniatowskiego, zajęła Kraków wraz z Galicją Zachodnią. Ziemie te zostały przyłączone do Księstwa Warszawskiego. W ten sposób miasto weszło znowu w nowy twór polityczny. I chociaż w Księstwie czyniono wysiłki, by krajowi zapewnić możność rozwoju przez szereg gospodarczych zarządzeń, to jednak niekorzystne ukształtowanie granic, niepewność położenia, przeciążenie finansowe ludności, a przede wszystkim podporządkowanie całego życia gospodarczego potrzebom politycznym, narzuconym przez Napoleona, nie liczącego się $z$ dobrem kraju, nie pomogło podźwignąć miasta $\mathrm{z}$ upadku'.

Klęska Napoleona w Rosji pociągnęła za sobą, m.in. likwidację Księstwa Warszawskiego. Rozpoczęty jesienią 1814 r. Kongres Wiedeński, którego zadaniem był nowy podział Europy i kolonii oraz zabezpieczenie mocarstw przed ewentualną ponowną agresją Francji, zajął się również sprawą Polski. Przede wszystkim chodziło o zmiany w ukształtowaniu granic państw zaborczych na ziemiach polskich. Na mocy postanowień Kongresu, z Krakowa i jego najbliższej okolicy na lewym brzegu Wisły utworzono Wolne Miasto - Kraków, pozostające pod opieką trzech mocarstw zaborczych. W ten kompromisowy sposób rozstrzygnięty został spór o Kraków między Rosją i Austrią ${ }^{6}$.

W 1835 r. Rosja i Austria postanowiły zlikwidować Rzeczpospolitą Krakowską. Realizacja tego postanowienia odwlekała się na skutek oporu Prus. Dopiero 11 października 1846 r. ogłoszono patent cesarza Ferdynanda, wcielający Kraków do Austrii. Aktu tego dokonano 16 listopada 1846 roku?

${ }^{3}$ S. Dobrzańs ki, Restauracja diecezji krakowskiej $w$ latach osiemdziesiatych XIX w., w: Studia z historii Kościota w Polsce, red. E. Wyczawski, t. 3, Warszawa 1977, s. 228.

${ }^{4}$ Cyt. za: S. Szcze panowski, Nędza Galicji $w$ cyfrach i program energicznego rozwoju gospodarstwa krajowego, Lwów 1888, s. 70, 73; R e d e r ow a, dz. cyt., s. 397.

${ }^{5}$ S. Kutrzeba, J. P taśni k, Dzieje handlu i kupiectwa krakowskiego, Kraków 1910, s. 40.

${ }^{6}$ Bieniarzówna, Małecki, dz. cyt., s. 153; Dobrzański, dz. cyt., s. 21.

7 J. De m e 1, Podstawy rozwoju nowoczesnego Krakowa w latach 1846-1956, w: Kraków, jego dzieje i sztuka, red. J. Dąbrowski, Warszawa 1956, s. 439; S. K i e n i e w i cz, Historia Polski 17951918, Warszawa 1983, s. 170. 
Rozbiory Polski uniemożliwiły przeprowadzenie reform w systemie oświaty, zaprojektowanych przez Komisję Edukacji Narodowej w 1773 r. Polityka państw zaborczych była opozycyjna względem tej postulowanej przez twórców KEN-u. Dążono do tego, by system oświaty nie był autonomiczny, ale jak najściślej podporządkowany organom administracji państwowej, ponieważ miał stanowić narzędzie centralistycznej polityki $\mathrm{w}$ procesie unifikacji ziem polskich z państwami zaborczymi.

Rząd austriacki nie dbał wcale o szkolnictwo elementarne. Szeregiem rozporządzeń ograniczył młodzieży uboższej, szczególnie wiejskiej, dostęp do szkół średnich i wkrótce przystąpił do jawnej germanizacji, która początkowo objęła szkoły wyższe ${ }^{8}$.

Krakowskie szkolnictwo, przynajmniej w pierwszej połowie XIX w., pod pewnymi względami miało korzystniejsze warunki pracy niż na innych terenach polskich. Represje polityczne były tu na ogół mniej dotkliwe. Poza pierwszym, przejściowym okresem germanizacji, aż do $1846 \mathrm{r}$. w szkołach panował polski język wykładowy i działały polskie władze szkolne. W porównaniu z całkowicie austriackim szkolnictwem Galicji i z zaborem pruskim, gdzie nauczyciele walczyli z germanizacją, szkolnictwo Krakowa wydaje się być ostoją polskości, wyizolowaną oazą spokoju”. W konsekwencji z tych szkół wyszło pokolenie, które potrafiło z ogromnym zapałem włączyć się w bieg życia społecznego, zachowując ducha narodowego, wrażliwość na zagadnienia polityczne oraz dostosowywało się do wymogów życia zawodowego. Była to w znacznej mierze zasługa systemu wychowania pozaszkolnego, które przekazywało wartości pomijane przez szkołę. Oddziaływało ono przez rodzinę, obyczaj, tradycję z jednej, a podziemne ruchy konspiracyjne $\mathrm{z}$ drugiej strony ${ }^{10}$.

Należy jednak pamiętać, że do szkół uczęszczali jedynie ci, którym na to pozwalały warunki materialne. Władzom zaborczym nie zależało na kształtowaniu młodzieży, ponieważ społeczeństwem żyjącym w ciemnocie i zacofaniu można było łatwiej kierować i utrzymać w posłuszeństwie dla władzy $^{11}$.

Galicja, będąca jedną z najbardziej zacofanych prowincji austriackich, była wraz z Krakowem terenem ekspansji kapitału, przemysłu i handlu austriackiego i zagranicznego. Stąd wszelkie projekty i plany ludzi światlejszych, chcących przeprowadzić reformę szkolnictwa krakowskiego, lub chcących nadać mu

${ }^{8}$ Oświata i szkolnictwo, s. 15-17; R. D u t kow a, Szkolnictwo średnie Krakowa w pierwszej potowie XIX w. (1801-1846), Wrocław 1976, s. 10-13.

${ }^{9}$ Dut k ow a, dz. cyt., s. 209.

${ }^{10}$ Tamże, s. 211; S. K i e n i e w i cz, Konspiracje galicyjskie (1831-1845), Warszawa 1950, s. 27. 28; J. Krajewsk i, Tajne zwiq̨zi polityczne w Galicji, Lwów 1903, s. 28-31.

${ }^{11} \mathrm{D}$ e m el, dz. cyl., s. 439-443. 
cechy szkolnictwa narodowego polskiego, natrafiały na te same trudności, głównie na niedostatek środków finansowych.

Znaczna część rodzin krakowskich, pominąwszy arystokrację i ziemiaństwo, kupców i rzemieślników, żyła w warunkach bardzo trudnych, wręcz w nędzy. Aby dobrze zapoznać się z biedą i nędza i zajrzeć jej w oczy, wystarczyło wyjść poza planty, które zakreślały granice starego Krakowa, a każdy niemal dom, każda ulica czy zaułek, obnażały smutną rzeczywistość miasta $^{12}$. W mieście nie przestrzegano czystości. Wszelkie zakłady przemysłowe były usytuowane w pobliżu murów, a wszystkie zanieczyszczenia usuwano poza mury. Bydło bito po domach, chlewy utrzymywano przy mieszkaniach. W takich warunkach stan zdrowotny ludzi, a zwłaszcza młodzieży przedstawiał się fatalnie. „Większa część indywiduów przedstawia organizm słabowity, częstokroć nawet co do kształtu lub do wzrostu mniej lub więcej upośledzony, skrofułami lub inną jaką dyskrazją przesiąkły, odznaczający się wątłością skóry i muskułów, słabemi kośćmi, tudzież cerą wyblakłą, a niekiedy nawet brudną"13. Zaś brakowi ruchu u młodzieży przypisywano pobudliwość seksualną.

Ówczesną nędzę Krakowa pogłębiały jeszcze klęski elementarne, dziesiątkujące ludność, a zwłaszcza dzieci: cztery epidemie w czasie głodu i posuch, dwukrotny wylew Wisły w 1813 i 1819 r., której brak było wałów ziemnych ${ }^{14}$, trzęsienie ziemi w 1844 r. i ogromny pożar Krakowa w 1850 r., w wyniku którego 1000 rodzin znalazło się bez dachu nad głową ${ }^{15}$. Do Krakowa, w którym nie brakowało nędzy, ciągnęli żebracy i bezrobotni z terenów podmiejskich, szczególnie w latach klęsk elementarnych.

Zmagania o odzyskanie niepodległości jak: powstanie listopadowe, rewolucja krakowska, zryw wolnościowy Wiosny Ludów, powstanie styczniowe przyniosły zniszczenia nie tylko materialne, ale i straty ludnościowe, a przez to podniósł się poziom sieroctwa społecznego ${ }^{16}$. Powiększający się procent

${ }^{12}$ Z. J a ku bows k i, Działalność ks. Franciszka Fabera CRL w Krakowie 1853-1868, Kraków 1874, s. 31.

${ }^{13}$ Cyt.: Galicyjskie wspomnienia szkolne, red. Z. Haraschin-Gutkowska, do druku przygotował i wstępem opatrzył A. Knot, Kraków 1955, s. 27-31; J. K on op n i c k i, Wychowanie fizyczne w szkole polskiej na przetomie XVIII $i$ XIX w., „Wychowanie Fizyczne i Sport” 1 (1957), s. 35-55; Dut kowa, dz. cyt., s. 149.

${ }^{14}$ Po powodzi w 1903 r., by zapobiec w przyszłości podobnym klęskom, rozpoczęto w 1907 r. budowę wałów wzdluż koryta rzeki. Pracami objęto odcinki od dzichnicy Zwierzyniec do mostu Dębnickiego oraz między dzielnicami Kazimierzem a Podgórzem. Demel, dz. cyt., s. 441; M. Fra nci c, Kalendarz dziejów Krakowa, Kraków 1864, s. 160.

${ }^{15}$ Francic wspomina, że pożar pochłonąl połowç budynków ówczesnego Krakowa. Spłonęło 160 domów, 4 kościoły i 2 klasztory. F r a n c i c, dz. cyt., s. 135.

${ }^{16}$ K. Lewicki, Przytulisko weteranów powstania 1863/64 r. w Krakowie, Kraków 1949, s. 3-6. 
opuszczonej dziatwy, walęsającej się po ulicach miasta dostarczał kandydatów na złodziei i potencjalnych przestępców ${ }^{17}$.

Problemy wychowawcze i społeczne starały się rozwiązywać instytucje dobroczynne i charytatywne, które istniały w Krakowie, ale było ich zbyt mało. Zakłady te były prowadzone przez organizacje kościelne, stowarzyszenia społeczne, samorządowe związki publiczne, osoby prywatne i fundacje ${ }^{18}$. Do najliczniejszych, o bogatej tradycji i posiadających własne źródła utrzymania, należały zakłady opiekuńczo-wychowawcze prowadzone przez Kościół, zwłaszcza przez zgromadzenia zakonne męskie i żeńskie. W drugiej połowie XIX w. nastąpiło odrodzenie działalności starszych zakonów. Równocześnie przybyłe do diecezji nowe zgromadzenia, powstałe w kraju lub wśród polskiej emigracji, a także powołane na miejscu w Krakowie, znalazły w przeciwieństwie do zaboru rosyjskiego i pruskiego dogodne warunki rozwoju i pole dla szerokiej działalności społeczno-dobroczynnej.

Celem niniejszej pracy nie jest omawianie działalności charytatywnej poszczególnych zakonów. Dla przykładu można jedynie przedstawić osoby najbardziej zaangażowane w tej pracy.

Wśród zakonników, w pierwszym rzędzie, należy wymienić Adama Chmielowskiego (św. brata Alberta), założyciela dwóch zgromadzeń posługujących ubogim (braci albertynów i sióstr albertynek), następnie kapucyna Wacława Nowakowskiego, jednego z najpopularniejszych zakonników ówczesnego Krakowa, znanego z wielu terenów działania ${ }^{19}$, Józefa Kalinowskiego (o. Rafała od św. Józefa) odnowiciela karmelitów bosych i karmelitanek krakowskich i ks. Franciszka Fabera ze Zgromadzenia Kanoników Regularnych Laterańskich, którego działalność trudno byłoby ująć w ramy którejś z oficjalnych instytucji dobroczynnych, działających $w$ tym czasie w Krakowie. Praca jego wśród najbiedniejszych, wychodząca daleko poza mury klasztoru Bożego Ciała, w którym mieściła się ogrzewalnia dla ubogich, powodowała nawet szereg konfliktów z ówczesnym przełożonym klasztoru, księdzem opatem Stanisła-

${ }^{17}$ Poważny problem dla Rady Miasta stanowiło usunięcie z ulic Krakowa plagi tzw. torebkarzy, czyli małoletnich przestępców kradnących portmonetki z damskich torebek. Częściowym usunięciem plagi zajął się Magistrat w porozumieniu z Dyrekcją Policji, przez wyłapywanie ich i odsyłanie do aresztów miejskich. S. P a r eńs k i, Nowe zakłady humanitarne Krakowa, Kraków 1912, s. 6.

${ }^{18}$ W. S a la, Praca $w$ zaktadach opiekuńczo-wychowawczych (w okresie 1918-1939), Warszawa 1964, s. 21.

${ }^{19}$ Nowakowski Edward (o. Waclaw) urodził się na Białorusi w $1839 \mathrm{x}$. w rodzinie szlacheckiej. Ukończył Uniwersytet Kijowski. Przez kilka lat pracował jako bibliotekarz, a w 31 roku życia wstąpił do kapucynów. Za udział w powstaniu styczniowym, jako kleryk został zesłany na Sybir. Po ucieczce z Sybiru wstąpił do prowincji galicyjskiej kapucynów i w 1880 r., w 51 roku życia, otrzymał święcenia kapłańskie. M. B.(art y now s ki), Nowakowski Wactaw, w: Podręczna Encyklopedia Kościelna, red. Z. Chełmicki, t. 29-30, Warszawa 1913, s. 81. 
wem Słotwińskim ${ }^{20}$. Obok nich na trwałe zapisał się w dziejach Krakowa kapelan szpitala św. Łazarza, ks. Kazimierz Siemaszko ze Zgromadzenia Księży Misjonarzy ${ }^{21}$, opiekun opuszczonych sierot i twórca „Domu schronienia i dobrowolnej pracy dla bezdomnych i opuszczonych chłopców" przy ul. Długiej 39. Podjął on pracę wychowawczą nad zaniedbanymi chłopcami, a w 1882 r., przy ofiarnej pomocy materialnej kilku arystokratek krakowskich, stworzył przy ulicy Długiej duży dom z warsztatami, zapewniając schronienie i naukę grupie chłopców ${ }^{22}$.

Wśród zakonnic nie zanotowano wielu szczególnie wybitnych nazwisk, m.in. chyba dlatego, że posiadały one bardziej ograniczone możliwości działania. Zakony żeńskie, obok działalności charytatywnej, poświęcały się głównie prowadzeniu szkół i internatów. Szkoły te powstawały przeważnie na przełomie XVIII i XIX stulecia, kiedy Kraków, po trzecim rozbiorze kraju, znalazł się przejściowo pod rządami austriackiego cesarza Józefa II. Wówczas klasztory lepiej wyposażone, aby ratować się przed józefińską kasatą, chciały wykazać się aktywną działalnością społeczną poprzez otwieranie szkół żeńskich, które raz powołane, egzystowały i po okresie józefinizmu.

$\mathrm{Na}$ polu działalności charytatywnej wszak wyróżniły się siostry miłosierdzia - szarytki, będące najliczniejszym zakonem żeńskim w diecezji. W Krakowie posiadały aż pięć domów ${ }^{23}$. Opiekowały się przede wszystkim chorymi w szpitalach: św. Łazarza, św. Ludwika (szpital dziecięcy) i w szpitalu psychiatrycznym Św. Ducha. Oprócz tego prowadziły szereg zakładów charytatywnych, np. w sierocińcu na Wesołej. Również siostry felicjanki posiadały znaczny udział w tego rodzaju pracy, tak pożytecznej dla szerokich rzesz potrzebujcych. Najbardziej znaną placówką tego zgromadzenia w Krakowie była bezpłatna kuchnia studencka siostry Samueli przy klasztorze na Smoleńsku, zorganizowana w 1873 r., w której, po przeniesieniu do osobnego budynku przyklasztornego, codziennie otrzymywało obiady do trzystu ubogich studentów i uczniów, a część z nich także i śniadania ${ }^{24}$. Subwencje na ten cel udzielały: magistrat, kapituła katedralna, Bank Pobożny, a najwięcej pomagały niektóre podkrakowskie dwory ziemiańskie i paru bogatszych mieszczan krakowskich, dostarczając prowiantu.

Oprócz zakonów działalność charytatywną prowadziły także stowarzyszenia i towarzystwa, skupiające w swych szeregach ludzi świeckich.

${ }^{20)} \mathrm{J}$ a ku bow ski, dz. cyt., s. 48-50.

${ }^{21}$ F. B im a, Ksiqdz Kazimierz Siemaszko, twórca dzieła miłości i poświęcenia, „Caritas”, 3 (1947) nr 4, s. 108-112; M. P i rózy ńs ki, Zakony męskie w Polsce, Lublin 1937, s. 181-182.

${ }^{22}$ B i m a, dz. cyt., s. 110; P i r oźy ń s k i, dz. cyt., s. 182; D obrzán s k i, dz. cyt., s. 208.

${ }^{23}$ ASMK, T. Siostry Miłosierdzia. Zakład Lubomirskich, Personel domów krakowskich.

${ }^{24}$ D obrzański, dz. cyt., s. 211-212. 
Krakowskie Towarzystwo Dobroczynności w 1816 r., po kilkunastoletniej przerwie, podjęło ponownie swoją działalność ${ }^{25}$. Działalność jego skupiała się głównie w obrębie murów starego Krakowa. Chociaż nie było instytucją kościelną, to jednak miało charakter katolicki. Jego protektorem był zazwyczaj ordynariusz krakowski ${ }^{26}$. Utrzymywało duży dom starców oraz roztaczało opiekę nad podrzutkami i nieślubnymi dziećmi. W 1855 r. rozpoczęło działalność Stowarzyszenie Pań Miłosierdzia św. Wincentego a Paulo, którego celem było łagodzenie nędzy krakowskiej. Powstało ono dzięki poparciu i inicjatywie kasztelanowej Felicji Wężykowej ${ }^{27}$, która poświęciła ubogim wiele czasu, trudu i pieniędzy. Założeniu i działalności Stowarzyszenia patronowała światła i energiczna wizytatorka ${ }^{28}$ sióstr miłosierdzia Matka Maria Tablot ${ }^{29}$. Widząc wspaniały rozwój Stowarzyszenia, utworzyła w jego łonie sekcję dla młodzieży, tzw. Stowarzyszenie Panien Ekonomek w 1860 r. Na terenie Krakowa, poza wymienionymi instytucjami dobroczynnymi, działało jeszcze Arcybractwo Miłosierdzia i Bank Pobożny oraz kilka bractw z ograniczonymi możliwościami jako Bractwo Najświętszego Sakramentu i Pięciu Ran Jezusa w parafii Bożego Ciała.

Pod koniec XIX w. na gruncie krakowskim zauważamy ożywienie zorganizowanej działalności charytatywnej, która była skutkiem ustawicznego wzrostu liczby ubogich i braku rozbudowanej urzędowej pomocy ${ }^{30}$. Być może, przyczyniła się do tego, powstała w 1899 r. pod egidą bpa Albina Dunajewskiego, Rada Związkowa Towarzystw Dobroczynnych, mająca na celu koordynację wszystkich wysiłków w dziedzinie miłosierdzia chrześcijańskiego.

${ }^{25}$ J. Majka, Dziatalność dobroczynna, ,Zeszyty Naukowe KUL”, 9 (1966) nr 1-2, s. 122.

${ }^{26}$ Duże zasługi w działalności tego Towarzystwa położył bp Albin Dunajewski. Był on protektorem prawie wszystkich stowarzyszeń i organizacji charytatywnych $\mathrm{w}$ tym czasie. Z. Krzyżanowska, Dobroczynność w Krakowie, w: Kraków w XIX w., t. 1, „Biblioteka Krakowa", nr 72, s. 182-184.

${ }^{27}$ Po klęsce pożaru w 1850 r. kasztelanowa Felicja Wężykowa zalożyła w 1855 r. Stowarzyszenie Pań Miłosierdzia w Krakowie. J. G a w or zew s k i, Przez 75 lat pracy Stowarzyszenia Pań Mitosierdzia $S_{w}$. Wincentego a Paulo w Krakowie (1855-1930), [bmw] 1830, s. 10-12.

${ }^{28}$ Najwyższym przełożonym sióstr miłosierdzia jest każdorazowy general Zgromadzenia Księży Misjonarzy. W jego imieniu rządzi bezpośrednio dyrektor generalny, misjonarz. Generał misjonarzy mianuje również urzędniczki - szarytki. Obok niego najwyższą władzę w Zgromadzeniu Sióstr Miłosierdzia piastuje przełożona generalna, wybierana co trzy lata. Poszczególnymi prowincjami rządzą wizytatorki. Wizytatorka ma do pomocy radę, składającą się z przynajmniej czterech sióstr, z których jedna jest asystentką. Ma też ekonomkę i sekretarkę. A. S c h l e t z, Zarys historyczny Zgromadzenia Sióstr Mitosierdzia w Polsce, Kraków 1960, s. 132; Konstytucje i Statuty Sióstr Mitosierdzia Św. Wincentego a Paulo, [bmrw], art. 81, 84, 85, 86, mps.

${ }^{29}$ Schletz, dz. cyt., s. 132; Gaworzewski, dz. cyt., s. 11.

${ }^{30} \mathrm{~J} . \mathrm{B}$ a r t os z e w i c z, Zarys historyczny opieki nad ubogimi w Galicji od czasu przytączenia jej do Austrii aż po chwilę obecna, w: Wiadomości statystyczne o stosunkach krajowych, red. T. Pilat, t. 18, Lwów 1901, s. 7-21. 
Zorganizowaną akcję charytatywną wspierała i uzupełniała prywatna dobroczynność, a filantropia stanowiąca ulubione zajęcie „pań z towarzystwa” przerodziła się w modę ${ }^{3 \dagger}$. Wśród nich zaznaczyła się księżna Marcelina Czartoryska, tercjarka karmelitańska, która jako stała przewodnicząca Towarzystwa Opieki Szpitalnej dla Dzieci, przeprowadziła zbiórkę funduszy na budowę szpitala dziecięcego św. Ludwika w Krakowie, otwartego w 1876 r., a następnie w $1887 \mathrm{r}$. przyczyniła się do otwarcia sanatorium w Rabce dla dzieci zapadajcych na schorzenia dróg oddechowych ${ }^{32}$.

W tym samym czasie powstały też w Krakowie trzy wielkie fundacje filantropijne. Miejscowa rodzina bankierska Helclów, wybudowała kosztem 560 tys. złotych reńskich (złr.) wielki gmach dla starców, nazwany imieniem fundatorów, a otwarty w 1890 roku $^{33}$. Zamieszkały w Paryżu książę Jerzy Aleksander Lubomirski ${ }^{34}$ złożył $2 \mathrm{mln}$ franków, za które wybudowano w 1893 r. wielki dom dla chłopców, przy ulicy Rakowickiej i drugi zakład dla dziewcząt, wzniesiony w latach 1889-1890 poza granicami miasta, w Łagiewnikach, powierzony kierownictwu Zgromadzenia Sióstr Matki Bożej Mitosierdzia - magdalenkom ${ }^{35}$.

\section{Początki funkcjonowania schroniska dla opuszczonej mlodzieży}

Wiek XIX, który przyniósł rozwój przemysłu fabrycznego, spowodował tym samym zubożenie rękodzielników. Dlatego sytuacja materialna wielu młodych terminatorów i czeladników była niejednokrotnie bardzo ciężka. Pogarszało ją w dodatku niebezpieczeństwo zepsucia moralnego, zwłaszcza,

${ }^{31}$ T. B oy-Że leń s k i, Znasz-li ten kraj, Kraków 1932, s. 29-30.

${ }^{32}$ W. Hor od y ń s k i, Czartoryská Marcelina, PSB, t. 4, Kraków 1938, s. 246-248; S. Ta rnow sk i, Ks. Marcelina Czartoryska, „Przegląd Polski”, 116 (1895) s. 17-294.

${ }^{33}$ Krakowski Kalendarz Czecha na rok 1891, s. 86; „Czas”, nr 167 z 23 VII 1890 1.; Dobrzańs k i, dz. cyt., s. 253.

${ }^{34}$ Jerzy Aleksander Lubomirski (1802-1893), wywodzący się z magnackiego rodu polskiego herbu Szreniawa, finansista i filantrop, był najmłodszym synem Ksawerego i jego trzeciej żony Marii Lwowny Naryszkin (zm. 1886 r.). Kształcił się prawdopodobnie w Petersburgu, był kamerjunkrem dworu cesarskiego. Wyjechał następnie do Paryża i dorobił się majątku na akcjach Kanału Sueskiego. W 1885 r. ofiarował 2 mln franków Wydziałowi Krajowemu we Lwowie na cele publiczne i naukowe. Ożeniony był z, o wiele starszą, Julią Radziwiłłówną. Małżeństwo po kilku latach rozpadło się. Zmarł bezdzietnie w Paryżu 12 czerwca $1893 \mathrm{r}$. W testamencie przekazał bratankom $16 \mathrm{mln}$ franków. J. B i e ni a rzów n a, Lubomirski Aleksander, PSB, t. 18, Wrocław 1973, s. 2; Bursa dla młodzieży rękodzielniczej i przemystowej im. Lubomirskiego w Krakowie (1911), PS, 12 (1928) nr 1, s. 31-32.

${ }^{35}$ J. R. B a r, Zgromadzenie Matki Bożej Miłosierdzia, w: Rozwój stanów doskonalości w Polsce, Warszawa 1966, nr 5, s. 69; Zgromadzenie Sióstr Matki Bożej Mitosierdzia 1862-1962, Józefów 1962, s. 25-26, mps. 
gdy pobierali naukę u niesumiennych majstrów, albo kiedy wędrowali w poszukiwaniu pracy ${ }^{36}$.

Taką właśnie młodzież miał na myśli książę Aleksander Lubomirski, kiedy 31 sierpnia 1885 r. ofiarował wspomnianą kwotę Wydziałowi Krajowemu we Lwowie na cele publiczne i naukowe. Suma ta, przekazana na ręce ówczesnego namiestnika Galicji, Filipa Zalewskiego, została wymieniona na walory austriackie i zgodnie $\mathrm{z}$ intencją ofiarodawcy podzielona na dwie części: na budowę zakładu dla dziewcząt i schronisko dla chłopców. Na rzecz schroniska przypadło przeszło milion koron austriackich ${ }^{37}$.

Książę Lubomirski zastrzegł $w$ akcie fundacyjnym, aby kapitał ten był przeznaczony „na urządzenie i utrzymanie schroniska dla chłopców opuszczonych lub zlego prowadzenia się"33. On też określił nazwę i położenie przyszłego zakładu: „Schronisko nosić ma nazwę: Schronisko fundacji księcia Aleksandra Lubomirskiego. Schronisko to ma być założone w Krakowie, lub jego najbliższej okolicy" 39 .

Po zatwierdzeniu aktu fundacyjnego przez Ministerstwo Spraw Wewnętrznych 13 października 1885 r. zakupiono od skarbu wojskowego w 1887 r. grunt w Olszy za cenę $23660 \mathrm{złr}^{40}$. Wiosną $1891 \mathrm{r}$. rozpoczęto budowę, którą prowadzili architekci: Tadeusz Stryjeński (1849-1949) i Władysław Ekielski (18551927). Gmach, zaprojektowany przez T. Stryjeńskiego, zdradzał cechy włoskiego renesansu ${ }^{41}$. Dodatkowe piętno wycisnął na budynku eklektyzm architektury Krakowa. Po dwu i półletnich pracach budowlanych, stosownie do woli fundatora, powstał budynek główny z budynkami administracyjnymi i gospodarczymi. Prawie siedmiohektarowy ogród, otoczony murem, zaopatrzony był w cieplarnię i budynek gospodarczy dla inwentarza żywego ${ }^{42}$. Dwupiętrowy budynek miał wspaniałą kopułę $\mathrm{w}$ środku, pod którą mieściła się kaplica

${ }^{36}$ J. S. P e lc z a r, Zarys dziejów mitosierdzia w Kościele katolickim, Kraków 1916, s. 208.

${ }^{37}$ Suma ta równała się wartości rocznego budżetu miasta Krakowa, który w 1880 r. wynosił milion koron. De me 1, dz. cyt., s. 447; Kilka stów o naszej bursie, „Echo Bursy”, 2 (1927) nr 910 , s. 3.

38 ArITSK, T. Zakład księcia Aleksandra Lubomirskiego w Krakowie, Akt fundacyjny na rzecz schroniska im. ks. A. Lubomirskiego w Krakowie (dalej cyt.: Akt fundacyjny), § 1.

39 Tamże, $\S 3$.

${ }^{40}$ ArITSK, A 554 Sprawozdanie z czynności schroniska fundacji ks. A. Lubomirskiego za lata 1893-1949, Sprawozdanie dyrekcji od 4 XI 1893 do 31 XII 1898; Schronisko Lubomirskich odżyło, „Echo Bursy”, 1 (1926) nr 1, s. 1-2.

${ }^{41}$ M. Kost a ne ck i, Twórczość architektoniczna Tadeusza Stryjeńskiego na tle epoki, Warszawa 1937, s. 31-37; A. Ś w i d a, Salezjańskie szkolnictwo w Polsce, w: 75 lat dziatalności salezjanów w Polsce, red. R. Popowski, S. Wilk, M. Lewko, Łódź 1974, s. 46.

${ }^{42} \mathrm{~S}$. Pły w a c z y k, Schronisko dla mlodzieży rękodzielniczej i przemystowej imieniem ksiecia Aleksandra Lubomirskiego w Krakowie, w: AH, zebrał S. Kosiński, Ląd n. Wartą 1966-1974, t. 6 , cz. 14 , s. 221 , mps. 
zakładowa, dzieląca zakład na dwie części. Jedna z nich, połączona korytarzem z przyległym piętrowym budynkiem, mieszczącym kuchnię, pralnię i szatnię, przeznaczona była dla młodszych chłopców i sióstr szarytek. Druga, również połączona korytarzem $\mathrm{z}$ bocznym piętrowym budynkiem, przeznaczona była dla starszych terminatorów i personelu świeckiego. Ksiądz dyrektor i kapelan mieszkali w oddzielnym, piętrowym budynku, połączonym także korytarzem z gmachem głównym zakładu. Wzdłuż ulicy, przed zakładem, stał domek dla odźwiernego, a po przeciwnej stronie domu, usytuowany był szpitalik ${ }^{43}$.

Książę A. Lubomirski nie doczekał chwili otwarcia i poświęcenia schroniska. Zmarł 12 czerwca 1893 r., na 185 dni przed jego otwarciem ${ }^{44}$. Poświęcenia zakładu dokonał kard. Albin Dunajewski, książę, biskup krakowski dnia 4 listopada 1893 r. Sporządzony na podstawie aktu fundacyjnego (zatwierdzony przez namiestnictwo 5 listopada 1892 r.) statut określat charakter przyszłej placówki, warunki przyjmowania chłopców oraz sposoby zapewnienia im wychowania i wykształcenia. Po uroczystym poświęceniu i otwarciu zakład zapełnił się młodymi mieszkańcami. Do schroniska przyjmowani byli chłopcy, którzy ukończyli ósmy rok życia, a nie przekroczyli piętnastego. Przyjęcie następowało na prośbę ich prawnych opiekunów lub też w wyniku zgłoszenia ich przez władze sądowe, policyjne lub gminne. Zakład przyjmował także chłopców nie mających żadnej opieki, a skierowanych tu przez władze administracyjne. W takim przypadku dyrekcja schroniska obowiązana była postarać się na właściwej drodze, aby dla przyjętych do zakładu chłopców, nie mających rodziców ani prawnego opiekuna, została przydzielona opieka prawna ${ }^{45}$. Oprócz metryki chrztu, życiorysu i zaświadczenia o stanie majątkowym rodziców, lub w razie ich braku, opiekuna, konieczna była opinia o chłopcu potwierdzona przez miejscowego proboszcza i władzę policyjną ${ }^{46}$.

$Z$ reguły do schroniska byli przyjmowani chłopcy katoliccy, sieroty i zaniedbani moralnie, pochodzący z Galicji. W schronisku mieli otrzymywać wychowanie religijne i moralne, zdobyć wykształcenie podstawowe i kwalifikacje zawodowe $\mathrm{e}^{47}$. Wszelkie więc przedsięwzięcia władz instytutu zmierzały do tego, aby wychowankowie wdrożyli się w życie uczciwie, a za pomocą odpowiedniego wykształcenia i systematycznych zajęć w kierunkach praktycznych rozwijali w sobie zamiłowanie do praktycznej pracy zawodowej i ścisłego wypełniania obowiązków, a w ten sposób wyrośli na pożytecznych członków

${ }^{43}$ Plywaczyk, dz. cyt., s. 221.

${ }^{44}$ ArITSK, T. Zaklad księcia Aleksandra Lubomirskiego w Krakowie, Akt fundacyjny, $§ 8$.

${ }^{45}$ ArITSK, T. Schronisko im. ks. A. Lubomirskiego, Statut Schroniska Fundacji Księcia Aleksandra Lubomirskiego, $\$ 7$ (dalej cyt.: Statut schroniska).

46 Tamże, Statut schroniska, $\$ 3$.

47 Tamże, $\$ 3$. 
społeczeństwa, a zarazem zapewnili sobie godny w przyszłości sposób zarobkowania i utrzymania ${ }^{48}$.

\section{Funkcjonowanie schroniska w latach 1914-1925, 1939-1946}

Po przejęciu administracji schroniska przez Zgromadzenie Salezjańskie z dniem 1 września 1911 r., jego działalność w 1914 r. z przyczyn obiektywnych została w dużym stopniu ograniczona ${ }^{49}$.

Pod koniec 1914 r. wojska austriackie zajęły na koszary i szpitale wojskowe szereg budynków mieszkalnych Krakowa. Los ten podzielił również zakład A. Lubomirskiego. W wyniku tego 180 wychowanków musiało opuścić gmach, zamieniony $\mathrm{z}$ tą chwilą na austriacki szpital wojskowy. Warto nadmienić, że były to jedyne obiekty szpitalne w Krakowie przeznaczone wyłącznie dla jeńców wojennych. Starsi wychowankowie zaciągnęli się do legionów ${ }^{50}$, a kilkudziesięciu młodszych (zupełne sieroty), po trzymiesięcznym pobycie w Woli Justowskiej pod Krakowem, w domu należącym do kurii biskupiej, zmuszonych było udać się wraz z wychowawcami na tułaczkę. W końcu zostali umieszczeni w salezjańskich zakładach w Daszawie i Radnej (Słowenia) ${ }^{51}$. Zżyli się $\mathrm{z}$ tamtejszą młodzieżą. Mieszkańcy Radnej pokochali młodych Krakusów i żegnali ich serdecznie, gdy w 1916 r. wyjeżdżali do Daszawy i Oświęcimia, aby w tamtejszym Zakładzie im. Ks. Bosko kształcić się w gimnazjum i szkole rzemieślniczej ${ }^{52}$.

Drugim ciosem, jaki zadała fundacji I wojna światowa, było prawie zupełne zniszczenie funduszu, przeznaczonego na utrzymanie sierot, gdyż na skutek dewaluacji przepadł milionowy ,żelazny kapitał”53.

Trzeba nadmienić, że przez cały okres wojny w szpitaliku zakładowym mieszkał ks. dyrektor i kilku salezjanów (m.in. ks. Stanisław Olszewski i ks. Józef Heintzel), którzy spełniali posługi duchowe względem rannych jeńców, głównie Włochów ${ }^{54}$. Bracia zakonni natomiast pracowali w ogrodzie.

${ }^{48}$ Por. Statut schroniska, $\$ 4$.

${ }^{49}$ W latach 1914-1925 i 1939-1946 budynki schroniska bezpośrednio nie służyły młodzieży.

50 25-lecie dziatalności salezjańskiej w Polsce, Mikołów 1923.

${ }^{51}$ Pamiqtka dwudziestopięciolecia zaktadu salezjańskiego w Daszawie 1905-1930, Warszawa 1930, s. 16-17; J. Ślósarczyk, Historia Prowincji Św. Jacka Towarzystwa Salezjańskiego w Polsce, t. 1, Pogrzebień 1960, s. 253, mps.

52 ArITSK, A 554 Sprawozdania z czynności schroniska fundacji ks. A. Lubomirskiego za lata 1893-1949, Sprawozdanie dyrekcji za rok 1916; Pły w a cz y k, dz. cyt., s. 223.

${ }^{53}$ Bursa dla mtodzieży rękodzielniczej i przemystowej im. Lubomirskiego w Krakowie (1911), PS, 12 (1928) nr 1, s. 32; Salezjańska Szkoła Zawodowa w Krakowie ul. Rakowicka 27, PS, 20 (1936) nr 1, s. 26.

${ }^{54}$ Kronika Zakładów Salezjańskich w Polsce: Kraków, PS, 1 (1916) nr 1, s. 14. 
Dnia 31 października 1918 r. wojsko polskie, dowodzone przez pułkownika Bolesława Boję, rozbiło oddziały austriackie, znajdujące się w mieście. Zlikwidowano wszelkie urzędy zaborçe i symbole austriackiego panowania ${ }^{55}$. Kraków stał się wolny. Wchodził w okres Polski niepodległej, w której walka o ostateczne ustalenie granic trwała jeszcze przez następnych kilka lat.

Wydawałoby się, że po zakończonej wojnie, powinni w schronisku zamieszkać chłopcy, zgodnie z przeznaczeniem powołanej instytucji dobroczynnej. Po zlikwidowaniu jednak polskiego szpitala wojskowego, utworzonego w $1918 \mathrm{r}$. w miejsce austriackiego, budynek przeznaczono na szpital dla wenerycznie chorych. Po jego zamknięciu schronisko zajęte było przez szereg lat na urzędy państwowe, m.in. przez Krakowskie Kuratorium Oświaty, policję i przeznaczono na mieszkania prywatne rodzin urzędników państwowych ${ }^{56}$. Dopiero w $1925 \mathrm{r}$. władze miejskie oddały schronisko z powrotem salezjanom w zarząd na zorganizowanie zakładu wychowawczego.

Salezjanie otrzymali jednak do dyspozycji tylko część zwolnionych pomieszczeń. Stopniowo i nie bez trudności usuwano lokatorów, zajmujących przeszło 30 pomieszczeń, tj. cały parter i sąsiedni budynek, służący przed wojną jako szpitalik zakładowy. Jeszcze w czerwcu 1929 r. mieszkało tam 15 rodzin. Dokładnie dwa lata później, w czerwcu 1931 r. zakład był opróżniony ${ }^{57}$. W dawnym szpitaliku mieszkał jeszcze Józef Niesiołowski (były urzędnik wojewódzki) i Józef Tyrpaka (pracownik Urzędu Wojewódzkiego). Mieszkania te, przydzielone im w 1925 r., przez Dyrekcję Robót Publicznych, opuścili oni jeszcze w 1931 r. Tak więc od tego już czasu schronisko w całości służyło młodzieży ${ }^{58}$.

Na pierwszy rok szkolny $1925 / 1926$ przyjęto 150 ubogich terminatorów, w tym 72 zupełne sieroty, którzy uczyli się zawodu u majstrów w mieście. Zakład, dzięki energicznemu kierownictwu dyrektora ks. Adama Cieślara (1925-1927), przeżywał w tych latach swój szczytowy okres rozwoju.

$\mathrm{Na}$ rok szkolny 1939/1940 zakład został wyremontowany i przygotowany na przyjęcie młodzieży. Ostatnie dni sierpnia osłabiały jednakże optymistycz-

${ }^{55}$ Francic, dz. cyt., s. 165.

${ }^{56}$ P ły w a c zy k, dz. cyt., s. 223; Z historii Bursy, „Echo Bursy”, 3 (1928) nr 8-10, s. 7; Bursa dla mtodzieży rękodzielniczej i przemystowej im. Lubomirskich w Krakowie (1911) PS, 12 (1928) nr 1, s. 32.

${ }^{57}$ Salezjańska Szkoła Zawodowa w Krakowie ul. Rakowicka 27, PS, 20 (1936) nr 1, s. 26; S. Ko s ińs k i, 75 lat pracy salezjańskiej w shużbie Kościola i narodu, „Nostra”, 28 (1973) nr 2, s. 4.

58 ArITSK, A 554 Sprawozdania z czynności fundacji ks. A. Lubomirskiego za lata 1893-1949, Sprawozdanie dyrekcji za okres od 1 IV 1930 r. do 31 III 1931 r., B 1504 Schronisko Lubomirskich. Kronika 1927-1950 (23 II - 15 X 1931); S. K o s i ń s k i, 75 lat pracy salezjańskiej w stużbie Kościoła i narodu, „Nostra”, 28 (1973) nr 2, s. 4; Salezjańska Szkota Zawodowa w Krakowie ul. Rakowicka 27, PS, 20 (1936) nr 1, s. 26. 
ne nastroje wśród dyrekcji jak i wychowanków. Coraz częściej mówiono o wojnie. Przebywający na miejscu w czasie wakacji chłopcy zaczęli się rozjeżdżać. W zakładzie pozostało 10 wychowanków, którzy pomagali dyrektorowi ks. Alojzemu Sękowskiemu w przemeblowaniu domu i odpowiednim jego porządkowaniu. Kosztowniejsze meble, sprzęt szkolny i świetlicowy zgromadzono w obszernej sali. Po pierwszym września większość współbraci udała się na tułaczkę na wschód. W zakładzie pozostali jedynie: ks. Sękowski, ks. Marian Mączyński (kapelan Cmentarza Rakowickiego), Stanisław Cyran (kierownik ogrodu), koadiutorzy: Franciszek Dereźiński (gospodarz), Walenty Jarosz i Wawrzyniec Budek oraz pracownice zatrudnione w ogrodzie ${ }^{59}$.

Podczas zajmowania Krakowa przez wojska niemieckie, okoliczna ludność schroniła się w piwnicach głównego gmachu. Dwa dni później, tj. 7 września, zakład został zajęty przez Niemców. „Bardzo mnie wtedy zdziwiło wspomina ks. A. Sękowski gdy zobaczyłem na własne oczy, jak żołnierze wniósłszy na korytarz jakąś skrzynię, zaraz z niej wyjęli plany zakładu i według nich rozmieszczali na drzwiach sal odpowiednie napisy orientacyjne z góry już przygotowane. Salę ze zgromadzonymi w niej meblami otwarto i meble według zapotrzebowania rozdzielono po lokalach ${ }^{60}$. Księdzu dyrektorowi pozostawiono tylko pokój sypialny. Pomieszczenia dyrekcji zarekwirowano $\mathrm{z}$ całym ich urządzeniem. Po kilku tygodniach zakład zajęły nowe jednostki niemieckiego Wehrmachtu, a współbracia musieli całkowicie opuścić budynek, nie mając już odtąd żadnego doń wglądu. Ksiądz dyrektor ze współbraćmi i 10 wychowankami zamieszkali w dawnym szpitaliku, a pracownice w bocznym budynku. To również nie podobało się Niemcom, dlatego wręczono ks. Sękowskiemu eksmisję z terenu zakładu. Interwencja księdza dyrektora $u$ niemieckiego prezydenta miasta, anulowała zarządzenie wojskowe. Wówczas chłopców, wraz $\mathrm{z}$ asystentem koad. Walentym Jaroszem, umieszczono u sąsiadujących $\mathrm{z}$ fundacją ojców karmelitów bosych. Jeden z budynków pozostał do dyspozycji dyrektora i współbraci. Byli oni tolerowani ze względu na pomoc przy uprawie ogrodu zakładowego. W pracy tej pomagało im kilku dawnych wychowanków. Tak przetrwali całą wojnę w warunkach bardzo ciężkich. Mimo to prowadzili wspólne życie zakonne: modlitwy, codzienna msza św. w kaplicy urządzonej z jednego pokoju i doroczne rekolekcje. Utrzymywali się zasadniczo $z$ ogrodu. Znaczne dochody czerpali z pasieki, którą dyrektor Sękowski zajmował się z zamiłowaniem.

${ }^{59}$ ArITSK, B 1504 Schronisko Lubomirskich. Kronika 1927-1950 (1939-1945); K r a wi e c, dz. cyt., s. 244-245; Ślós a r c z y k, dz. cyt., t. 3, s. 233-234.

${ }^{60}$ Warto nadmienić, że akt fundacyjny był sporządzony w Paryżu w $1885 \mathrm{r}$. w języku polskim i nienieckim. ArITSK, B 1504 Schronisko Lubomirskich. Kronika 1927-1950 (1939-1945); \$ ló s a r c zy k, dz. cyt., t. 3, s. 134. 
Dzięki nieustępliwej postawie ks. Sękowskiego i jego troskliwości w czasie wojny uratowano paramenty kościelne, bibliotekę, naczynia kuchenne i część drobniejszego inwentarza ${ }^{61}$.

Urząd Generalnego Gubernatorstwa, po rocznym okupowaniu Krakowa, pismem z dnia 14 września 1940 r. zwrócił się do Kurii Metropolitalnej w Krakowie $z$ następującym zarządzeniem: „W myśl par. 1. rozporządzenia o prawie fundacji w Generalnym Gubernatorstwie [...] mają być fundacje, zdolne do działań prawnych zgłoszone przez swoje organa upoważnione do ich zastępstw. Rozporządzeniu podlegają wszystkie fundacje [...] a tym samym fundacje kościelne. Zgłoszenie należy [...] kierować do Wydziału Zarządu Wewnętrznego w Krakowie Generalnego Gubernatorstwa, Kraków, Gmach Rządowy do dnia 30 września 1940 roku"62.

Kuria biskupia wysłała odpisy powyższego pisma do fundacji działających w Krakowie i najbliższej okolicy, w liczbie ośmiu, w tym także do schroniska im. A. Lubomirskiego. Do zgłoszenia należało dołączyć statut (list fundacyjny), wyciąg z ksiąg metrykalnych, jeśli fundacja rozporządzała majątkiem nieruchomym i sprawozdanie dotyczące użytkowania dochodów majątku w czasie od 1 września 1939 r. do sierpnia 1940 r. W razie braku któregos z powyższych dokumentów należało wysłać wierzytelny odpis. Wszystkie winny być przełożone na język niemiecki ${ }^{63}$. Zebrane dokumenty zostały przedłożone Urzędowi Generalnego Gubernatorstwa przez Radę Główną Opiekuńczą, działającą przy kurii. Było to formalne przejęcie zakładu przez okupanta. Faktyczna okupacja trwała już od roku. W 1942 r. budynek zajęły po Wehrmachcie wojska Luftwaffe. Lotnicy zmodernizowali całkowicie zakład według swoich potrzeb, rabując przy tym, m.in. zamki i klamki miedziane, a miedziane przewody instalacji elektrycznej zamienili na aluminiowe. Lotnicy, odmówili od początku płacenia czynszu, który dotąd przeznaczano na remont zewnętrzny zakładu. Taki stan trwał do końca 1944 roku $^{64}$.

Armia Czerwona zbliżyła się do przedmieść Krakowa 17 stycznia 1945 r., od strony północnej i północno-wschodniej, zaskakując nie przygotowane na atak z tej strony siły niemieckie. Następnego dnia nastąpiło wyzwolenie Krakowa. Wojsko II Frontu Ukraińskiego, pod dowództwem marszałka Iwana Koniewa, zajęło miasto, a cofające się oddziały niemieckie, nocą 18 stycznia,

${ }^{61}$ ArITSK, A 563 Krakow-Rakowicka 27. Schronisko im. ks. A. Lubomirskiego. Wizytacje inspektorialne 1934-1938 1945-1947, Sprawozdanie inspektora Ślósarczyka z wizytacji domu Opieki Najświętszej Maryi Panny (Schronisko im. ks. Lubomirskiego) z 5 I 1946 r.; S lósa r czyk, dz. cyt., t. 3 , s. 135 .

${ }^{62}$ AKMKr, AF 318 Ak1a Fundacji 1940, Urząd Generalnego Gubernatorstwa do Ordynariatu Arcybiskupiego w Krakowie 14 IX 1940 r.

${ }^{63}$ Por. Tamże.

${ }^{64}$ Ślós a rczy k, dz. cyt., t. 3, s. 135. 
opuściły zakład $^{65}$. Po opuszczeniu schroniska przez okupanta ludność z sąsiednich domów uczyniła formalny napad, rabując i wynosząc $z$ zakładu co tylko się dało.

Mimo, że Miejska Opieka Społeczna zajęła się zabezpieczeniem obiektu, do budynku weszły wojska sowieckie. Chociaż uzgodniono, że zajmą tylko połowę parteru i dwa baraki, to jednak nie wpuszczono do zakładu księdza dyrektora, mieszkajcego ze wspóbraćmi w dawnym szpitaliku. Wkrótce zapełnił się on więźniami z Oświęcimia, cudzoziemcami: Francuzami, Belgami i Włochami. I teraz dopiero nastąpiła kolejna dewastacja obiektów. Z powodu braku węgla palono poniemieckie meble, okna, drzwi, parkiety, klęczniki, a nawet sprzęt $\mathrm{z}$ kaplicy ${ }^{66}$.

W maju 1945 r. zakład przemieniono na szpital wojskowy. Od chwili wyzwolenia dyrektor ks. Sękowski czynił w Zarządzie Miejskim i w Urzędzie Wojewódzkim bezskuteczne starania o odzyskanie budynku fundacji. Na ponowną interwencje w styczniu $1946 \mathrm{r}$. w komendzie wojsk sowieckich, dnia 15 lutego 1946 r. zakład przeszedł pod administrację salezjanów ${ }^{67}$.

Dyrektorem został ks. Sękowski, prefektem ks. Antoni Bursiewicz, katechetą ks. Czesław Rogowski, radcą zakładu ks. Edmund Żołyniak, a kierownikiem oratorium ks. Marian Wiertelak. Przystąpiono natychmiast do remontu budynków. Ksiądz dyrektor zgłosił w Urzędzie Wojewódzkim 18 lutego, że przenosi się z wychowankami, którzy w czasie wojny mieszkali u karmelitów, na swe dawne miejsce. $W$ ten sposób sformułowane zgłoszenie nie stanowiło utworzenia nowej placówki, ale kontynuację administrowania w schronisku, zakłóconego działaniami wojennymi. Władze miejskie, nie mając podstawy do sprzeciwu, udzieliły pozwolenia. Pod koniec 1946 r. funkcjonowała już w zakładzie męska bursa dla 76 wychowanków. Pismem z dnia 22 marca 1947 r. dyrekcja wysłała „kartę rejestracyjną” bursy do Ministerstwa Oświaty, Kuratorium Okręgu Szkolnego Krakowskiego i do Inspektoratu Szkolnego Miejskiego ${ }^{68}$.

\section{Przejęcie i likwidacja schroniska przez władze PRL}

Kiedy zakład zaczął już funkcjonować zainteresowała się nim kuratoria fundacji. Jej prezes dr Kazimierz Pasenkiewicz 21 sierpnia 1946 r. skierował

65 ArITSK, B 1504 Schronisko Lubomirskich. Kronika 1927-1950 (I-II 1945).

${ }^{66}$ Ślós a r czy k, dz. cyt., t. 3, s. 136.

${ }^{67}$ ArITSK, A 563 Kraków-Rakowicka 27. Schronisko im. ks. Lubomirskiego. Wizytacje inspektorialne 1934-1938 1945-1947, Sprawozdanie z wizytacji inspektora Ślósarczyka z 6 I 1946 r., B 1504 Schronisko Lubomirskich. Kronika 1927-1950 (1946 -1950); Slósarczyk, dz. cyt., t. 3, s. 136-137.

${ }^{68}$ ArTTSK, B 1504 Schronisko Lubomirskich. Kronika 1927-1950 (1946-1950); P ł y w a c z y k, dz. cyt., s. 223; Odbudowa Dzieta Salezjańskiego w Polsce, PS, 24 (1946) nr 1, s. 16. 
do dyrekcji pismo o przygotowanie sprawozdania z działalności zakładu od sierpnia 1939 r. i o wyznaczenie terminu posiedzenia kuratorii. W grudniu 1948 r. przewodniczący kuratorii (był wojewodą Krakowa) zawiadomił dyrektora ks. A. Sękowskiego, że kuratoria schroniska, na posiedzeniu w dniu 10 listopada 1948 r., postanowiła rozwiązać umowę ze Zgromadzeniem Salezjańskim, co do dalszego prowadzenia schroniska. Wezwał również dyrektora do oddania zarządu schroniska, wraz z całym majątkiem, osobom, które w dniu 5 stycznia 1949 r. zgłoszą się do zakładu ${ }^{69}$. W odpowiedzi prowincjał wystąpił na drogę sądową. Udzielił pełnomocnictwa procesowego adwokatowi krakowskiemu Jerzemu Ossowskiemu, do zastępowania Towarzystwa Salezjańskiego wobec władz administracyjnych i sądowych $\mathrm{w}$ sprawie $\mathrm{z}$ kuratorią fundacji im. A. Lubomirskiego ${ }^{70}$.

Towarzystwo Salezjańskie, przez swego pełnomocnika, odwołało się do ministra Spraw Wewnętrznych w Warszawie, z prośbą o unieważnienie uchwały kuratorii $z$ dnia 10 listopada 1948 r. oraz zarządzenia jej przewodniczącego z dnia 6 grudnia 1948 r. Adwokat J. Ossowski wyjaśniał, że decyzja kuratorii została powzięta bez żadnej podstawy prawnej. Paragraf 10 umowy, zawartej 12 lipca $1911 \mathrm{r}$. między kuratorią schroniska, a ówczesnym prowincjałem ks. Emanuelem Manassero, którego zastępował ks. Jan Świerc, zatwierdzonej przez Namiestnictwo we Lwowie 4 sierpnia 1911 r., postanawial: „Każdej stronie będzie służyć prawo tę umowę na dwa lata przed 1 lipca 1926 r. wypowiedzieć a to na piśmie. Gdyby takie wypowiedzenie nie nastąpiło, przedłuży się umowę pod tymi samymi warunkami milcząco na dwa lata itd.". Paragraf wcześniejszy przewidywał jej rozwiązanie na skutek orzeczenia sądowego. W tym przypadku argumentował Ossowski takiego orzeczenia nie było, ani też nie zostały powzięte przez kuratorię fundacji żadne kroki zmierzające do takiego uznania ${ }^{71}$. Pomijając powody natury prawnej, uchwała kuratorii i jej przewodniczącego powinna być anulowana, ponieważ, z chwilą kiedy kapitał fundacyjny stracił wszelką wartość, Towarzystwo Salezjańskie przejęło na siebie koszty utrzymania zakładu. Personel salezjański zakładu od 1926 r. pracował społecznie, nie pobierając żadnego wynagrodzenia. Ówczesny dyrektor ks. Sękowski od 20 lat też pracował bezpłatnie. Prowadził ponadto stację doświadczalną jako pszczelarz-naukowiec, a za osiągnięcia w tej dziedzinie otrzymał przed wojną Złoty Krzyż Zasługi ${ }^{72}$. W sumie Towarzystwo Salezjań-

${ }^{69}$ ArITSK, A 11 Likwidacja. Schronisko Lubomirskich, Przewodniczący Kuratorii do Konwentu XX Salezjanów 6 XII 1948 r.

${ }^{70}$ ArITSK, A 11 Likwidacja. Schronisko Lubomirskich, Slósarczyk do adwokata Ossowskiego 15 XII $1948 \mathrm{r}$.

${ }^{71}$ Tamże, Ossowski do Ministra Spraw Wewnętrznych w Warszawie, grudzień 1948 r.

72 Tamże, Pismo Ossowskiego z grudnia 1948 r. 
skie zatrudniało 13 pracowników fizycznych, których zwolnienie w zimie przyniosłoby dla nich nie powetowane straty materialne i moralne.

W dniu 16 grudnia 1948 r. adwokat Ossowski powiadomił przewodniczącego kuratorii, iż Zgromadzenie Salezjańskie, przed rozpatrzeniem sprawy przez ministra Spraw Wewnętrznych, nie zastosuje się do decyzji wojewody Pasenkiewicza.

Niezależnie od swego pełnomocnika, Inspektorat Towarzystwa Salezjańskiego w Krakowie czynił osobne starania w tej sprawie. Jeszcze w grudniu 1948 r. zwrócił się do ministra Oświaty w Warszawie ${ }^{73}$, jako władzy naczelnej instytucji wychowawczych i Domów Dziecka, z prośbą o unieważnienie pisma i decyzji wojewody krakowskiego. W tej samej sprawie wysłał petycję do Prezydium Rady Ministrów w Warszawie przez Urząd Wojewódzki w Krakowie $^{74}$.

Zarówno wysłane przez pełnomocnika, jak i przez Inspektorat Towarzystwa Salezjańskiego petycje w sprawie anulowania decyzji kuratorii $z$ dnia 10 listopada 1948 r. oraz zarządzenia jej przewodniczącego z dnia 6 grudnia 1948 r. do wojewódzkich i centralnych władz państwowych i oświatowych pozostały bez odpowiedzi. Inspektor prowincji św. Jacka z siedzibą w Krakowie wraz ze swą radą ${ }^{75}$, wniósł sprawę w styczniu 1949 r. do Sądu Okręgowego w Krakowie przeciw fundacji im. A. Lubomirskiego, działającej przez kuratorię, aby sąd orzekł, iż umowa z 1911 r., o przedmiocie zarządu i kierownictwa zakładu, obowiązuje nadal oraz, że uchwała kuratorii i decyzja jej przewodniczącego są bezzasadne wobec Zgromadzenia Salezjańskiego ${ }^{76}$. Sąd Okręgowy w Krakowie również nie zajął żadnego stanowiska w tej sprawie.

W takim stanie oczekiwania i niepewności pracowali salezjanie przez przeszło półtora roku. Wreszcie nadszedł ostateczny cios. Dnia 25 sierpnia 1950 r. Wojewódzka Komisja Lokalowa, powołując się na decyzję Prezydium Wojewódzkiej Rady Narodowej z 25 sierpnia tegoż roku, nakazywała wycho-

73 ArITSK, A 11 Likwidacja. Schronisko Lubomirskich, Inspektorat Towarzystwa Salezjańskiego w Krakowie do Ministra Oświaty w Warszawie 26 XII 1948 r.

74 Tamże, Pismo Inspektoratu Towarzystwa Salezjańskiego do Prezydium Rady Ministrów w Warszawie przez Urząd Wojewodzki w Krakowie 26 XII 1948 r.

75 "Inspektor stosownie do potrzeb prowincji, ma przydanych sobie czterech, a najmniej dwóch radców, których, po wysłuchaniu zdania inspektora wybiera Przełożony Generalny z Kapitułą Wyższą. Pozostają w swym urzędzie trzy lata i mogą być ponownie wybrani [...] By ktoś mógł być wybrany na radcę inspektorialnego [...] wymaga się, aby był kapłanem, przeżył w Towarzystwie przynajmniej pięć lat i miał śluby wieczyste", Ustawy i Regulaminy Towarzystwa Św. Franciszka Salezego, Warszawa 1925, art. 91, 94 (Ust.); Statut Towarzystwa Salezjańskiego, Warszawa 1933, § 40.

${ }^{76}$ ArITSK, A 11 Likwidacja. Schronisko Lubomirskich, Adwokat Ossowski do Sądu Okręgowego w Krakowie z 4 I 1949 r. 
wawcom i wychowankom opuścić bursę do 30 sierpnia 1950 roku ${ }^{77}$. Wychowankowie, w liczbie 100 , w tym 55 ze względu na sieroctwo opłacani przez skarb państwa, mieli zostać umieszczeni w zakładach wychowawczych prowadzonych przez państwo. Dyrektor fundacji odwołał się jednak od decyzji tejże komisji, uznając ją za nieprawną, bo wydaną wbrew postanowieniu art. 75 ust. 1 Ustawy o postępowaniu administracyjnym (Dz.U.R.P. nr 36, poz. 341 z 1938 r.). Decyzja ta nie zawierała ponadto pouczeń, czy przysługuje odwołanie, $w$ jakim terminie $\mathrm{i}$ do jakiej władzy ${ }^{78}$. W dodatku decyzja ta była sprzeczna $z$ postanowieniem art. 101 lit. a, b, d Rozporzadzenia R.P. o postepowaniu administracyjnym $\mathrm{z}$ dnia 22 marca 1928 r. (Dz.U.R.P. nr 36 poz. 341), ponieważ WKL nie była władna do likwidowania lub zawieszania działalności osób prawnych. Decyzja ta sprzeczna była także z art. 101 o postępowaniu administracyjnym, gdyż nie powoływano się w niej na żadną podstawę prawną. W końcu niemożliwe było zlikwidowanie instytucji ze 100 wychowankami w ciągu trzech dni.

O niejasnej sytuacji bursy w tamtych latach świadczą nieliczne dokumenty, znajdujące się w Archiwum Towarzystwa Salezjańskiego w Krakowie. Mianowicie, 18 sierpnia $1950 \mathrm{r}$. dyrektor schroniska otrzymał ustne polecenie od Wojewódzkiej Komisji, złożonej z przedstawicieli województwa, Nowej Huty i Zakładu im. ks. Kuznowicza, w sprawie przyjmowania chłopców na nowy rok szkolny 1950/1951, do czego się zastosowal ${ }^{79}$. Ponadto odpowiednie władze państwowe dwukrotnie zwracały się do dyrekcji, by zakład przyjął większą liczbę chłopców na rok szkolny 1950/1951, skierowanych przez Wydział Oświaty. Jednak na mocy uchwały Prezydium Wojewódzkiej Rady Narodowej z 25 sierpnia 1950 r. zakład wychowawczy fundacji im. A. Lubomirskiego zlikwidowano ${ }^{80}$.

W dniu 22 września 1950 r. dyrekcja otrzymała z Prezydium WRN w Krakowie dwa pisma. Pierwsze z Wydziału Społeczno-Administracyjnego, podpisane przez przewodniczącego WRN dra K. Pasenkiewicza, w którym prosi on o wypożyczenie Wydziałowi Oświaty 40 łóżek, w związku z mającym nastąpić przeniesieniem wychowanków do Państwowego Domu Dziecka w Bieżanowie, a także o wypożyczenie dalszego sprzętu. Drugie pismo z Wydziału Oświaty, podpisane przez kierownika tegoż, Stanisława Ptaszyńskiego,

${ }^{77}$ Tamże, Wojewódzka Komisja Lokalowa w Krakowie do Bursy ul. Rakowicka 27 dnia 26 VIII $1950 \mathrm{r}$.

${ }^{78}$ Tanłże, Odwołanie dyrektora zakładu im. A. Lubomirskiego ks. Alojzego Sękowskiego do WKL w Krakowie z 29 VIII 1950 r.

${ }^{79}$ Tamże, Inspektor Jan Ślósarczyk do Ministerstwa Oświaty w Warszawie, Al. I Armii WP 25 dnia 30 VIII $1950 \mathrm{r}$.

${ }^{80}$ Tamże, Odwołanie Ślósarczyka do Prezydium Rady Ministrów w Warszawie przez Prezydium WRN w Krakowie 3 X $1950 \mathrm{r}$. 
decydujące kategorycznie o likwidacji zakładu ${ }^{81}$. Przewodniczący prosił o wypożyczenie, a podległy mu kierownik wydziału nie prosił lecz rozkazywał. Trudno obecnie dowieść, czy kierownik Wydziału Oświaty działał wbrew i bez porozumienia ze swym przełożonym. Pewne jest jednak, że zadysponował majątkiem prywatnym fundacji, osoby prawnej, do czego nie miał prawa. W tym samym dniu, tj. 22 września, zabrany został z zakładu sprzęt: łóżka, pościel, szafki nocrie i inne przedmioty dla 34 chłopców do Państwowego Domu Dziecka w Bieżanowie. Stopniowo kierowano wychowanków do innych zakładów państwowych: do Domu Dziecka w Bieżanowie 23 września 1950 r. przeniesiono 37 wychowanków, do Zakładu Ks. Siemaszki 30 wychowanków 30 września, pozostałych 8 udało się do rodziców lub na stancje ${ }^{82}$.

Dalszym etapem likwidacji fundacji było komisyjne przekazanie świetlicy szkolnej w dniu 2 października 1950 r. komitetowi rodzicielskiemu i kierownictwu Szkoły Podstawowej nr 3 w Krakowie, na polecenie Wydziału Oświaty Prezydium WRN z dnia 30 września tegoż roku. Świetlicę, wraz z przylegającym terenem, przeznaczono na urządzenie „świetlicy zielonej”, tj. ogrodu jordanowskiego ${ }^{83}$. Przy przekazywaniu świetlicy byli obecni: kierownik świetlicy ks. A. Sękowski, instruktor ogrodów jordanowskich z Wydziału Oświaty Helena Schneider, dyrektor szkoły podstawowej Tadeusz Wroński, prezes komitetu rodzicielskiego Józef Bętkowski i członek komitetu rodzicielskiego Helena Łazowska, nauczycielka Szkoły Podstawowej nr 3 w Krakowie.

Przewodniczący kuratorii, powołując się na decyzję WKL z 26 lipca 1950 r., zarządzająca opuszczenie fundacji, oraz na podstawie uchwały kuratorii z dnia 2 października tegoż roku, przekazał budowle fundacji Zrzeszeniu Studentów Polskich w Krakowie. Nieruchomości te przejęli: Jerzy Chrząstowski prezes i Białań delegat Ministra Szkół Wyższych w Krakowie ${ }^{84}$.

Niewielka ilość przedmiotów, zwłaszcza obrazy religijne, sprzęt liturgiczny, krzesła, łóżka, materace i kołdry, stanowiące własność salezjanów, zostały przejęte 26 października 1957 r. przez Inspektorat Towarzystwa Salezjańskie-

81 „W związku z likwidacją zakładu wychowawczego z dn. 30 bm. odchodzi 39 wychowanków będących w zakładzie na odpłatności skarbu państwa do Państw. Domu Młodzieży w Bieżanowie. Reszta zaś młodzieży przejdzie w dn. 30 bm. do Zakładu Wychowawczego ks. Siemaszki w Krakowie". ArITSK, A 11 Likwidacja. Schronisko Lubomirskich, Prezydium WRN Wydział Oświaty w Krakowie do Zakladu Wychowawczego Fundacji ks. A. Lubomirskiego w Krakowie z 21 IX $1950 \mathrm{r}$.

82 ArITSK, A 11 Likwidacja. Schronisko Lubomirskich, Odwołanie Ślósarczyka do Prezydium Rady Ministrów w Warszawie 3 X 1950 r., A 539 Schronisko im. ks. A. Lubomirskiego. Spis wychowanków 1912-1939 1946-1950, Raport statystyczny za miesiąc sierpień $1950 \mathrm{r}$.

83 ArITSK, A 11 Likwidacja. Schronisko Lubomirskich, Protokół zdawczo-odbiorczy XX Salezjanów dla Publicznej Szkoły Powszechnej III stopnia nr 3 im. Św. Mikołaja w Krakowie z 2 X $1950 \mathrm{r}$.

${ }^{84}$ Tamże, Pismo Przewodniczącego kuratorii stanowiące o likwidacji fundacji z 3 X 1950 r. 
go prowincji św. Jacka w Krakowie od ks. Sękowskiego, mieszkającego do tego czasu przy ul. Rakowickiej $27^{85}$.

Po drugiej wojnie światowej, w nowej rzeczywistości polityczno-społecznej Polski Ludowej, po 57 latach działalności społeczno-charytatywnej, fundacja schroniska im. A. Lubomirskiego w Krakowie, ,mająca istnieć po wieczne czasy, służąc młodzieży ubogiej i opuszczonej”, została przekazana na użytek Wyższej Szkoły Ekonomicznej ${ }^{86}$.

\section{ROZDZIAŁ II ZARZAZD I PERSONEL SCHRONISKA}

\section{Kierownictwo i personel schroniska}

\section{a) pod zarządem diecezjalnym}

Książę Aleksander Lubomirski, fundując dla zaniedbanej młodzieży męskiej instytucję, której nadał charakter religijno-wychowawczy, pomyślał również o personelu administracyjno-wychowawczym, mającym kierować tą placówką: „Przy poruczaniu nadzoru w zakładzie należy dać pierwszeństwo siostrom zakonnym" ${ }^{, 7}$. Na stanowiskach kierowniczych widział siostry zakonne jednego z klasztorów krakowskich.

Na terenie Krakowa jak wiadomo działało kilka zakonów żeńskich, wychowujących wszakże wyłącznie dziewczęta. Jedynie siostry miłosierdzia szarytki, zajmowały się działalnością charytatywno-opiekuńczą wśród młodzieży żeńskiej i męskiej. Pod koniec XIX w. szarytki z pięciu domów krakowskich pracowały w szkołach podstawowych i wieczorowych, szpitalach dla starców i umysłowo chorych, w zakładach opiekuńczych dla podrzutków i w stowarzyszeniach wincentyńskich ${ }^{88}$. Im też postanowiono oddać w zarząd nowo utworzoną fundację.

Delegat Namiestnictwa w Krakowie, Laskowski, który w imieniu c.k. Rządu sprawował bezpośredni nadzór nad budową gmachu, zaproponował w styczniu 1893 r. przełożonym sióstr miłosierdzia w Krakowie przy ul. Warszaw-

85 ArITSK, A 548 Schronisko im. ks. A. Lubomirskiego, Inwentarz schroniska podzielony między zakłady po likwidacji $1957 \mathrm{r}$.

${ }^{86}$ ArITSK, A 11 Likwidacja. Schronisko Lubomirskich, Księża salezjanie do Wyższej Szkoły Ekonomicznej w Krakowie 2 X 1950 r.; P ł y wa cz y k, dz. cyt., s. 223.

${ }^{87}$ ArITSK, T. Zakład księcia Aleksandra Lubomirskiego w Krakowie, Akt fundacyjny, art. 7.

${ }^{88}$ Siotry miłosierdzia sprowadzone zostały do Krakowa w 1714 r. przez bpa Michała Szembeka, sufragana krakowskiego. AKMKr, T. Siostry Miłosierdzia. Zakład Lubomirskich, Statystyki domów krakowskich; S c h le tz, dz. cyt., s. 16; Kalendarz katolicki na rok Pański 1889, Kraków, s. 144. 
skiej 6, podjęcie pracy w schronisku ${ }^{89}$. Siostry miałyby zająć się chłopcami od ósmego do dziesiątego roku życia. Oprócz miesięcznego wynagrodzenia zakład zapewniał: mieszkanie, wyżywienie i całkowite utrzymanie. Wizytatorka prowincji krakowskiej, s. Karolina Juhel, odpowiadając na propozycję delegata Namiestnictwa z dnia 19 I 1893 r., wyraziła wstępną aprobatę co do ewentualnego podjęcia pracy przez siostry w schronisku. Podała jednocześnie warunki, na jakich siostry mogłyby podjąć pracę w zakładzie. W gruncie rzeczy były one identyczne $\mathrm{z}$ tymi, na podstawie których podejmowały pracę w szkolnictwie w Galicji ${ }^{90}$. Najważniejszy z nich, a zarazem kontrowersyjny był punkt dotyczący rent sióstr już po przepracowaniu 10 lat w zakładzie, na wypadek choroby, która uniemożliwiałaby dalszą pracę. Delegat Namiestnictwa nie chciał się na ten warunek zgodzić. W końcu 3 października 1893 r. siostry przyjęły kompromis i zawarły umowę z kuratorią fundacji. Podpisy pod tym aktem złożyli: ze strony kuratorii delegat Namiestnictwa, Laskowski, a ze strony sióstr miłosierdzia wizytatorka, s. K. Juhel ${ }^{91}$. Urząd Namiestnictwa zatwierdził $29 \times 1893$ r. tę umowę ${ }^{92}$. Zawierała ona także postanowienia końcowe, dotyczące czasu trwania umowy i rozwiązania jej. Czas ten był nieograniczony, a wypowiedzenie należało złożyć na 6 miesięcy naprzód ${ }^{93}$.

Dyrektorem schroniska został ks. Antoni Lang, kapłan diecezjalny. Do jego kompetencji należały: nadzorowanie działalności schroniska, jego administracja oraz przyjmowanie chłopców lub ich usuwanie. Na usunięcie wychowanka musiał uzyskać zgodę kuratorii. We wszystkich niemal sprawach, odnoszących się do wychowania młodzieży, dyrektor zakładu zawsze zobowiązany był porozumieć się z kuratorią.

Nad życiem religijno-moralnym wszystkich mieszkańców schroniska mieli czuwać dyrektor i kapelan. Tym ostatnim został ks. Józef Kaczmarczyk. Uczył on religii wszystkich wychowanków, odprawiał codziennie dla nich mszę św. i nabożeństwa w kaplicy zakładowej. W kazaniach i przy każdej innej sposobności starał się wszczepiać w serca młodzieży zasady wiary i moralności chrześcijańskiej. O wszelkich niedociągnięciach informował dyrektora i razem z nim podejmował odpowiednie decyzje. Był on także bezpośrednim przełożonym sióstr pracujących w zakładzie i pośrednikiem między przełożonymi sióstr miłosierdzia, a dyrekcją schroniska w sprawach dotyczących pracy sióstr. Po-

${ }^{89}$ ASMK, T. Zakład Lubomirskich, Laskowski do przełożonych sióstr miłosierdzia z 19 I 1893 r.; S c h 1 e t z, dz. cyt., s. 133.

${ }^{90}$ ArSMK, T. Zakład Lubomirskich, S. Karolina Juhel do Namiestnika Galicji 26 I 1893 r.

${ }^{91} \mathrm{~S}$. Karolina Juhel pełniła urząd wizytatorki prowincji małopolskiej (krakowskiej) w latach 1881-1905. ArSMK, T. Zakład Lubomirskich, Umowa między Kuratorią z Zgromadzeniem Sióstr Miłosierdzia z 23 X 1893 r. (dalej cyt.: Umowa).

92 Tamże, Pismo c.k. Namiestnictwa we Lwowie z 29 X 1893 r.

${ }^{93}$ ASMK, T. Zakład Lubomirskich, Umowa, § 3. 
nadto zastępował dyrektora w czasie jego nieobecności lub choroby. Kapelan zatem pełnił funkcję zastępcy dyrektora schroniska ${ }^{94}$.

Nadzór nad wychowankami w zakładzie prowadziły w pierwszym roku jego funkcjonowania siostry miłosierdzia. Wychowankowie, w wieku od 8 do 10 lat, byli umieszczeni w części zakładu zamieszkałej przez siostry, przez co miały one możliwość ustawicznego oddziaływania na nich. Wspólnie z nimi odprawiały codzienne praktyki duchowne, pielęgnowały ich w czasie choroby, organizowały dla maluchów wycieczki do miasta i w najbliższe jego okolice. Oprócz tego zarządzały kuchnią, spiżarnią, pralnią i szatnią zakładową. Dbałość o kaplicę, należała również do ich kompetencji ${ }^{95}$.

W późniejszych latach w miarę wzrostu liczby klas i uczniów funkcję dozoru wychowawczego pełnili także wychowawcy świeccy i nauczyciele. Statut schroniska precyzował dokładnie wymagania, jakim musieli odpowiadać wychowawcy, zanim zostali przyjęci do pracy w zakładzie. Mieli to być mężczyźni nieżonaci, cieszący się dobrą opinią, posiadajcy wykształcenie pedagogiczne, a jeśli tego wymagała praca także i zawodowe. Mieszkali w zakładzie i czuwali nad wychowankami starszymi, dozorując ich w sypialniach, jadalni, w czasie rekreacji i w pracowniach, przy pracach fizycznych w obrębie budynków zakładowych. Sami mieli wykonywać pewne prace fizyczne wraz z wychowankami, aby tym samym dać im przykład dobrej pracy. Można powiedzieć, że przez całą dobę byli odpowiedzialni za podwładnych ${ }^{96}$.

Pierwotny cel i organizację schroniska określał szczegółowo statut, zatwierdzony przez Namiestnictwo 5 listopada 1892 r. Przeznaczono go na zakład wychowawczo-poprawczy dla chłopców, w którym mieli oni otrzymać wychowanie i wykształcenie. Wychowaniu religijno-moralnemu służyły szczególnie codzienne praktyki pobożne: msza św., częste przystępowanie do sakramentów św. (nie pod presją), nauka piesni religijnych i modlitw, które poprzedzały i kończyły posiłek, pracę i spoczynek. Coroczne rekolekcje, odprawiali wychowankowie przez trzy dni w okresie Wielkiego Postu. Głosił je zaproszony z zewnątrz kapłan. Rozkład rekolekcji był stały, a porządek dnia wyglądał następująco: ${ }^{97}$ godz. 5.30 - pobudka godz. 6.00 - modlitwy poranne godz. 6.30 - śniadanie

94 AKMKr, 202 Salezjanie, Ks. Lang do Książęco-Biskupiego Konsystorza w Krakowie 8 VI 1896 r.; ArITSK, T. Schronisko im. ks. A. Lubomirskiego, Statut schroniska, \$ 35.

95 ArITSK, T. Schronisko im. ks. A. Lubomirskiego, Statut schroniska, § 38; ArSMK, T. Przejęcie zakładu Lubomirskich, Umowa, § 1.

${ }^{96}$ ArITSK, T. Schronisko im. ks. A. Lubomirskiego, Statut schroniska, § 42; Salezjańska Szkota Zawodowa w Krakowie ul. Rakowicka 27, PS, 20 (1936) nr 1, s. 36.

97 ArITSK, B 1503 Kraków-Lubomirscy. Kronika, Rozkład rekolekcji odprawianych od 24-26 III $1911 \mathrm{r}$. 
godz. 7.30 - nauka I, po nauce msza św. z wystawieniem Najświętszego Sakramentu

godz. 10.00-10.30 - czytanie duchowne

godz. 11.00 - nauka II, rachunek sumienia

godz. 12.00-14.00 - obiad, czas wolny

godz. 14.00 - nauka III, cząstka Różańca św.

godz. 16.00-16.30 - czytanie duchowne

godz. 17.00 - nauka IV, błogosławieństwo

godz. 18.00 - kolacja

godz. 19.30 - modlitwy wieczorne, rachunek sumienia

godz. 21.00 - spoczynek

Główną rolę w procesie edukacji wychowanków odgrywała, zorganizowana od samego początku w schronisku, szkoła ludowa. W pierwszym roku szkolnym 1893/1894 funkcjonowała szkoła jednoklasowa dla I i II stopnia nauki, która z każdym rokiem szkolnym wzrastała o jedną klasę, tak że od roku szkolnego 1896/1897 nosiła nazwę i charakter czteroklasowej szkoły ludowej z prawami szkół publicznych ${ }^{98}$.

W szkole tej nauka przebiegała według programu zatwierdzonego przez Radę Szkolną Krajową 27 marca 1893 r. Obejmował on następujące przedmioty: religia, język polski, czytanie, pisanie, nauka o rachunkach w połączeniu $z$ nauką o formach geometrycznych, śpiew i gimnastyka. Ponadto w klasie II, III i IV rysunki, a w klasie III i IV język niemiecki ${ }^{99}$.

Oprócz nauki przewidzianej planem szkolnym udzielano wychowankom, w czasie wolnym od zajęć szkolnych i codziennych prac porządkowych, nauki śpiewu kościelnego, chóralnego, gry na instrumentach smyczkowych i organach (dla starszych) oraz nauki zręczności pod kierunkiem kwalifikowanych nauczycieli, dochodzących z zewnątrz. Dodatkowo uczono szewstwa i krawiectwa. Tę praktyczną naukę dyrekcja wprowadziła w tym celu, aby wychowaniu młodzieży i jej edukacji nadać kierunek praktyczny, przynajmniej w minimalnym stopniu. Wreszcie w porze letniej wychowankowie pracowali w ogrodzie zakładowym ${ }^{100}$.

Dla terminatorów, uczących się praktycznej nauki zawodu u rękodzielników w mieście, dyrekcja schroniska zorganizowała wieczorową naukę uzupeł-

98 ArITSK, A 554 Sprawozdania z czynności schroniska fundacji ks. A. Lubomirskiego za lata 1893-1949, Sprawozdanie z czynności dyrekcji od 4 XI 1893 do 31 XII 1898, A 581 KrakówRakowicka 27. Katalog główny z wykazem klasyfikacyjnym od 1894 do 1903 r., A 582 KrakówRakowicka 27. Schronisko im. ks. A. Lubomirskiego. Katalog główny 1903-1911, B 1503 KrakówLubomirscy. Kronika (1896-1897).

${ }^{99}$ ArITSK, A 582 Kraków-Rakowicka 27. Schronisko im. ks. A. Lubomirskiego. Katalog główny 1903-1911.

${ }^{100}$ ArITSK, A 554 Sprawozdania z czynności schroniska fundacji ks. A. Lubomirskiego za lata 1893-1949, Sprawozdanie dyrekcji od 3 XI 1893 do 31 XII 1898, Sprawozdanie za rok 1902. 
niającą. Młodsi terminatorzy uczyli się na miejscu. Starsi uczęszczali do szkół miejskich wieczorowych (Szkoła Przemysłowo-Dokształcająca w Krakowie ul. Lubomirskiego) i tam zdobywali świadectwa, których otrzymanie potrzebne było do „wyzwolin" na czeladnika. Władze szkolne zastrzegły, że nie otrzyma świadectwa czeladniczego uczeń, który nie ukończy wieczorowej szkoły uzupełniającej ${ }^{101}$.

Program nauki uzupełniającej obejmował przedmioty: religię, język polski w połączeniu z nauką stylistyki, język niemiecki, rachunki, rysunek odręczny i geometryczny, śpiew w połączeniu z nauką muzyki i gimnastykę. Przystępujący do nauki rzemiosła musieli ukończyć 14 rok życia.

W roku szkolnym 1896/1897 pierwszych 30 uczniów klasy IV ukończyło szkołę ludową. W miarę zdolności skierowano ich: 2 do gimnazjum, 14 do szkoły wydziałowej, 6 do nauki rzemiosła, a pozostałych 8 (jako niezdolni do dalszej nauki, a do rzemiosła za młodzi) dyrekcja postanowiła na kolejny rok szkolny pozostawić w klasie IV.

Tab. nr 1: Liczba wychowanków zakładu w latach 1893-1899

\begin{tabular}{|l|c|c|c|c|c|c|c|}
\hline & $1893 / 4$ & $1894 / 5$ & $1895 / 6$ & $1896 / 7$ & $1897 / 8$ & $1898 / 9$ & suma \\
\hline przyjętych & 32 & 30 & 14 & 17 & 15 & 16 & 124 \\
\hline odeszło & - & - & - & 1 & 3 & 3 & 7 \\
\hline pozostało & 32 & 30 & 14 & 16 & 12 & 13 & 117 \\
\hline z tych do: & 32 & - & - & - & - & 33 & $?$ \\
\hline kl. I i II & - & 28 & 16 & 15 & 12 & - & $?$ \\
\hline kl. I & - & 34 & 28 & 22 & 19 & - & $?$ \\
\hline kl. II & - & - & 32 & 25 & 32 & 27 & $?$ \\
\hline kl. III & - & - & - & 30 & 19 & 26 & $?$ \\
\hline kl. IV & - & - & - & - & 14 & 12 & $?$ \\
\hline kl. V wydz. & - & - & - & - & - & 12 & $?$ \\
\hline kl. VI wydz. & - & - & - & - & 2 & - & $?$ \\
\hline kl. I gim. & - & - & - & - & 6 & 11 & $?$ \\
\hline kI. I uzupeł. & 32 & 62 & 76 & 92 & 104 & 117 & 117 \\
\hline razem & & & & & & \\
\hline
\end{tabular}

Źródło: ArITSK, A 554 Sprawozdania z czynności schroniska fundacji ks. A. Lubomirskiego za lata 1893-1949, Sprawozdanie z czynności dyrekcji od 4 XI do 31 XII 1898.

${ }^{101}$ Poprzez to uczniowie ci mieli możność prezentacji swoich prac na wystawie w mieście. W 1902 r. dwóch uczniów zakładu otrzymało srebrne medale za swoje prace rzemieślnicze, a kolejni dwaj listy pochwalnc. ArITSK, A 554 Sprawozdania z czynności fundacji ks. A. Lubomirskiego za lata 1893-1949, Sprawozdanie dyrekcji za rok 1902; AKMKr, 202 Salezjanie, Kuria do kapelana schroniska ks. A. Hlonda 4 X $1906 \mathrm{r}$. 
Rok szkolny w zakładzie kończono w uroczystej oprawie zewnętrznej. Po nabożeństwie dziękczynnym w kaplicy, w udekorowanej sali gimnastycznej rozpoczynała się akademia. Składały się na nią deklamacje, śpiewy, popisy muzyczno-wokalne i gimnastyczne. Przy tej okazji dyrekcja organizowała wystawy prac uczniów: pisemne wypracowania stylistyczne, rysunki geometryczne i zawodowe, wyroby rzemieślnicze. Prezentowano także produkty z ogrodu. Tego rodzaju uroczystościom patronował zazwyczaj prezes kuratorii. Brali w niej udział członkowie kuratorii, okręgowy inspektor szkolny, majstrowie terminatorów, rodzice i opiekunowie uczniów oraz zaproszeni goście ${ }^{102}$. Program popisu wychowanków na zakończenie roku szkolnego dnia 26 czerwca 1904 r. obejmowat: ${ }^{103}$

godz. 8.00 - nabożeństwo dziękczynne

godz. 9.00 - akademia w sali gimnastycznej:

1. modlitwa Ojcze nasz,

2. deklamacja,

3. wieniec krakowiaków (śpiew uczniów klasy III),

4. ćwiczenia laskami i na koźle przy muzyce (uczniowie klas III i IV),

5. „Pieśń wieczorna” Stanisława Moniuszki i „Andante” Krzysztofa Willibalda Glucka,

6. deklamacja „Powrót taty” Adama Mickiewicza,

7. śpiewy starszych wychowanków: „Barkarola” Suszyńskiego, „Pieśń górska”

Kückena, „Ułan” Listowskiego,

8. deklamacja „Bitwa pod Racławicami” Teofila Lenartowicza,

9. ćwiczenia gimnastyczne na poręczach,

10. „Laure” Jana S. Bacha na skrzypce i fortepian,

11. ćwiczenia warsztatowców na koniu i piramidy,

12. „Wieniec polski” w wykonaniu orkiestry dętej,

13. śpiewy starszych wychowanków: „Strój polski” melodia ludowa, „Przy krosnach" S. Moniuszki, „W las” R. Wagnera,

14. odczytanie klasyfikacji wychowanków, rozdanie nagród, odczytanie wykazu statystycznego za rok szkolny 1903/1904,

15. hymn ludowy,

16. modlitwa Zdrowaś Maryjo,

17. zwiedzanie zakładu i wystawy prac uczniów.

Uczniom odznaczającym się dobrymi wynikami w nauce i pilnością wręczano nagrody w formie książeczek oszczędnościowych $z$ wkładem kilku koron każda. Ponadto terminatorom, którzy według umowy otrzymywali tygodniowe

${ }^{102}$ ArITSK, A 554 Sprawozdania z czynności schroniska fundacji ks. A. Lubomirskiego za lata 1893-1949, Sprawozdania dyrekcji za rok 1893-1898, 1900, 1902, 1903, 1907, 1909, 1910.

103 ArITSK, A 554 Sprawozdania z czynności schroniska fundacji ks. A. Lubomirskiego za lata 1893-1949, Sprawozdanie dyrekcji za rok 1907 (luźna kartka z programem z 1904 r.). 
lub miesięczne niewielkie wynagrodzenie od majstrów, przełożeni lokowali te pieniądze w Powiatowej Kasie Oszczędności. Z tych niewielkich kwot niektórzy uczniowie uzbierali znaczniejsze sumy. W roku szkolnym 1908/1909 dyrekcja przechowywała 74 książeczki oszczędnościowe, będące własnością wychowanków. Niektórzy mieli po kilka koron, inni większe sumy: tapicer Gliński 289 koron, tapicer Wątorek 239 koron, tapicer Ziajka 109 koron, brązownik Włodek 128 koron. Terminatorzy ci, opuszczając zakład otrzymywali swoje wkłady oszczędnościowe.

$\mathrm{Na}$ wakacje nie wyjeżdżali wszyscy wychowankowie. Pozostawali na miejscu zwłaszcza ci, którzy nie mieli rodziców, rodziny czy opiekunów. W godzinach przedpołudniowych poświęcano dwie godziny na naukę, część dnia na pracę fizyczną w ogrodzie oraz na ćwiczenia sportowo-gimnastyczne i wycieczki.

Mówiąc o młodzieży i jej wychowaniu, należy wspomnieć o karności w zakładzie. Młodzież rekrutowała się, w większości, z najuboższych warstw społecznych, zazwyczaj zaniedbanych moralnie. Niosło to za sobą pewne nawyki i nałogi, które wychowawcy starali się usunąć. Żadne wykroczenie wychowanka nie pozostawało bez kary, a wzorowe zachowanie bez nagrody. Za wykroczenia właściwe wiekowi szkolnemu (swawola, przywłaszczenie sobie cudzej własności, lenistwo, nieposłuszeństwo, niszczenie obuwia i ubrania) dyrekcja nakładała stosowne kary: pozbawienie śniadania, obiadu lub kolacji, surowa nagana, pozbawienie czasu przeznaczonego na zabawę, zamknięcie w karcerze, kara cielesna. Tę ostatnią stosowano w nadzwyczajnych wypadkach i wymierzano ją w obecności wychowawcy - ochmistrza ${ }^{104}$.

Dla ewidencji zachowania wychowanków zaprowadzono w zakładzie „księgę obyczajów”. Wpisywano do niej każdego miesiąca wykroczenia poszczególnych uczniów i kary im wymierzane. Ponadto każdy z dozorców miał własną książeczkę, w której notował wykroczenia spostrzeżone i każdego tygodnia przedkładał je ochmistrzowi, który wpisywał je do „księgi obyczajów"105.

Koszty urządzenia gmachu w pierwszych latach funkcjonowania pokrywano $\mathrm{z}$ kwoty przeznaczonej przez fundatora na ten cel. Rozliczenia z dochodów i wydatków otrzymywało namiestnictwo krajowe w miesięcznych i rocznych sprawozdaniach dyrekcji. Z każdym jednak rokiem wzrastała liczba wycho-

${ }^{104}$ Wymierzanie kar za cięższe przekroczenia należało wylącznie do dyrekcji. Nikomu z personelu wychowawczego nie wolno było na własną rękę wymierzać kar cielesnych. Za ucieczkę z zakładu (uważane za największe wykroczenie) dyrekcja nie karała wydaleniem ze schroniska, jak czyniono to w podobnych instytucjach. ArITSK, A 554 Sprawozdania z czynności schroniska fundacji ks. A. Lubomirskiego za lata 1893-1949, Sprawozdanie dyrekcji od 4 XI 1893 do 31 XII $1898 \mathrm{r}$.

105 Tamże, Sprawozdanie dyrekcji od 4 XI 1893 do 31 XII 1898. 
wanków, a co za tym idzie i koszty funkcjonowania placówki. Te jednak w rocznych preliminarzach budżetowych pozostawały stałe, a nawet były nieznacznie zmniejszane.

W zakładzie, po otwarciu szkoły ludowej i zwiększaniu liczby jej klas, posady nauczycieli obsadzano siłami własnymi, tj. pedagogami zamieszkałymi w zakładzie. W piątym roku funkcjonowania schroniska, dla wychowanków kończących szkołę ludową, zachodziła potrzeba ich dalszego kształcenia w klasach wydziałowych. Wobec niemożności zapewnienia nauczycielom z funduszów fundacji stałej pensji emerytalnej, po przepracowaniu odpowiedniej liczby lat, dyrekcja w porozumieniu z kuratorią postanowiła nie otwierać klas wydziałowych na miejscu. Uczniów tych kierowano do miejskich szkół wydziałowych i przemysłowych, starszych terminatorów na naukę zawodu do odpowiednich rzemieślników. Rękodzielników tych, jako zaufanych i sumiennych, przedstawiała dyrekcji kuratoria. Warunki przyjęcia, przebieg praktyki, obowiązki i prawa praktykantów oraz ich majstrów regulowały umowy zawierane przez dyrekcję ${ }^{106}$.

Kierując się względami oszczędnościowymi, została podjęta decyzja o likwidacji z dniem 1 września 1898 r., szkoły ludowej w schronisku. Zakładowa młodzież szkolna została skierowana do miejskich szkół ludowych. Odprowadzali ją codziennie świeccy wychowawcy zakładowi. Rada Miasta Krakowa oraz Rada Szkolna stawiały trudności w przyjmowaniu wychowanków do szkół miejskich. W uzasadnieniu podawano, że zakład nie leży na terenie miasta Krakowa lecz gminy Czerwony Prądnik. Zażądano, by dyrekcja płacila za każdego przyjętego ucznia 20 koron. W tej sytuacji dyrekcja utrzymała na miejscu klasę III i IV szkoły ludowej. Jako szkoła wewnętrzna realizowała program szkół miejskich, a w późniejszych latach zwiększyła liczbę klas do czterech. Do nauki w klasach I-III zatrudniono siostry szarytki, pracujące w schronisku, a w klasie IV uczył Stanisław Lang, emerytowany kierownik szkoły publicznej $\mathrm{z}$ miasta ${ }^{107}$.

106 Tamże, Sprawozdanie dyrekcji za rok 1902, 1907, 1908, 1910.

${ }^{107}$ Likwidacja szkoły miała okazać się racjonalną także z tego powodu, że młodzież w szkołach publicznych mogła korzystać z bogatszych zbiorów i pomocy naukowych, a to miało przyczynić się do podniesienia poziomu kształcenia. ArITSK, A 554 Sprawozdania z czynności schroniska fundacji ks. A. Lubomirskiego za lata 1893-1949, Sprawozdanie dyrekcji od 4 XI 1893 do 31 XII 1898. 
Tab. nr 2: Nauczyciele szkoły ludowej w schronisku w latach 1896-1911

\begin{tabular}{|c|c|c|c|}
\hline $\mathrm{rok} / \mathrm{szk}$. & klasa & gospodarz-wychowawca & nauczyciel religii \\
\hline \multirow[t]{4}{*}{$1896 / 1897$} & I & Franciszek Pększy & ks. Józef Kaczmarczyk \\
\hline & II & Karol Skwarczowski & ks. Józef Kaczmarczyk \\
\hline & III & Stanisław Resiuła & ks. Józef Kaczmarczyk \\
\hline & IV & Ksawery T. Szumański & ks. Józef Kaczmarczyk \\
\hline \multirow[t]{2}{*}{$1897 / 1898$} & III & Karol Skwarczowski & ks. Józef Kaczmarczyk \\
\hline & IV & Leon Starnawski & ks. Józef Kaczmarczyk \\
\hline $1899 / 1900$ & I, II & $\begin{array}{c}\text { Franciszek Pększy } \\
\text { s. Stanisława }\end{array}$ & \\
\hline \multirow[t]{2}{*}{$1900 / 1901$} & I, II & s. Stanisława & \\
\hline & IV & Franciszek Kapłański & \\
\hline \multirow[t]{2}{*}{$1901 / 1902$} & I, II & s. Stanisława & \\
\hline & III & $\begin{array}{l}\text { s. Józefa (I półrocze) } \\
\text { s. Paula (II półrocze) }\end{array}$ & \\
\hline $1904 / 1905$ & I, II & s. Stanisława & \\
\hline \multirow[t]{2}{*}{$1905 / 1906$} & 1 & s. Urlik & ks. August Hlond \\
\hline & IV & Stanisław Lang & ks. August Hlond \\
\hline \multirow[t]{3}{*}{$1906 / 1907$} & I, II & s. Urlik & ks. August Hlond \\
\hline & III & s. Bronisława & ks. August Hlond \\
\hline & IV & Stanisław Lang & ks. August Hlond \\
\hline \multirow[t]{3}{*}{$1907 / 1908$} & I, II & s. Urlik & ks. Stanisław Plywaczyk \\
\hline & III & s. Bronisława & ks. Stanisław Pływaczyk \\
\hline & IV & Stanisław Lang & ks. Stanisław Pływaczyk \\
\hline \multirow[t]{3}{*}{$1908 / 1909$} & II & s. Urlik & ks. Jerzy Kalinowski \\
\hline & III & s. Maria Neugeouna & ks. Jan Szlachta \\
\hline & IV & Stanisław Lang & ks. Jan Szlachta \\
\hline $1909 / 1910$ & IV & Stanisław Lang & \\
\hline $1910 / 1911$ & III & s. Cecylia & \\
\hline
\end{tabular}

Źródło: ArITSK, A 58l Kraków-Rakowicka 27. Katalog główny z wykazem klasyfikacyjnym od 1894 do 1903 r., A 582 Kraków-Rakowicka 27. Schronisko im. ks. A. Lubomirskiego. Katalog główny 1903-1911, A 618 Lubomirscy. Katalog klasyfikacyjny 1896-1903.

W latach 1893-1911, gdy w schronisku pracowały siostry miłosierdzia, liczba wychowanków nie była stała. Najwięcej, bo 175, było w roku szkolnym 
1907/1908. Sporządzona statystyka, na podstawie dostępnych źródeł wskazuje, iż w latach 1898-1911 liczba wychowanków nie zawsze dorównywała normie określonej statutem fundacji z 18 lipca 1892 roku $^{108}$.

Tab. nr 3: Liczba wychowanków schroniska fundacji im. A. Lubomirskiego w Krakowie w latach 1893-1911

\begin{tabular}{|c|c|}
\hline rok & liczba wychowanków \\
\hline $1893 / 1894$ & 32 \\
\hline $1894 / 1895$ & 62 \\
\hline $1895 / 1896$ & 76 \\
\hline $1896 / 1897$ & 92 \\
\hline $1897 / 1898$ & 104 \\
\hline $1898 / 1899$ & 117 \\
\hline $1899 / 1900$ & 132 \\
\hline $1900 / 1901$ & 135 \\
\hline $1901 / 1902$ & 135 \\
\hline $1902 / 1903$ & 152 \\
\hline $1903 / 1904$ & $?$ \\
\hline $1904 / 1905$ & $?$ \\
\hline $1905 / 1906$ & 145 \\
\hline $1906 / 1907$ & $?$ \\
\hline $1907 / 1908$ & 175 \\
\hline $1908 / 1909$ & 151 \\
\hline $1909 / 1910$ & 142 \\
\hline $1910 / 1911$ & 80 \\
\hline
\end{tabular}

Źródło: ArITSK, A 554 Sprawozdania z czynności schroniska fundacji ks. A. Lubomirskiego za lata 1893-1949, Sprawozdania z czynności dyrekcji za lata 1893-1898, 1900, 1902, 1903, 1907, 1909, 1910, A 581 Kraków-Rakowicka 27. Katalog główny z wykazem klasyfikacyjnym od 1894 do 1903 r., A 582 Kraków-Rakowicka 27. Schronisko im. ks. A. Lubomirskiego. Katalog główny 1903-1911.

Wychowankowie, którzy ukończyli klasę IV szkoły ludowej wewnętrznej w zakładzie zdawali egzamin w szkole miejskiej pw. św. Mikołaja i otrzymywali

${ }^{108}$ Normalny etat internistów wynosił 120. ArITSK, T. Schronisko im. ks. A. Lubomirskiego, Statut schroniska, $\$ 9$. 
świadectwa jej ukończenia. Stosownie do otrzymanych wyników przechodzili do szkół wydziałowych, gimnazjów i na naukę terminu ${ }^{109}$.

Tab. nr 4: Liczba uczniów szkoły ludowej w schronisku w latach 1899-1911

\begin{tabular}{|r|c|c|c|c|c|}
\hline rok & kl. I & kl. II & kl. III & kl. IV & razem \\
\hline $1893 / 94$ & 32 & - & - & - & 32 \\
\hline $1894 / 95$ & 28 & 35 & - & - & 63 \\
\hline $1895 / 96$ & 16 & 28 & 32 & - & 76 \\
\hline $1896 / 97$ & 15 & 22 & 25 & 30 & 92 \\
\hline $1897 / 98$ & 12 & 19 & 32 & 19 & 82 \\
\hline $1898 / 99$ & 11 & 22 & 20 & 20 & 73 \\
\hline $1899 / 900$ & 7 & 22 & 24 & 23 & 76 \\
\hline $1900 / 01$ & 9 & 18 & 20 & 22 & 69 \\
\hline $1901 / 02$ & 5 & 25 & 19 & 18 & 67 \\
\hline $1902 / 03$ & 15 & 21 & 21 & 20 & 77 \\
\hline $1903 / 04$ & 21 & 19 & 21 & 22 & 83 \\
\hline $1904 / 05$ & 12 & 27 & 19 & 22 & 80 \\
\hline $1905 / 06$ & 15 & $?$ & 29 & 19 & 63 \\
\hline $1906 / 07$ & 14 & 22 & 26 & 28 & 90 \\
\hline $1907 / 08$ & 7 & 20 & 26 & 26 & 79 \\
\hline $1908 / 09$ & 9 & 20 & 20 & 26 & 75 \\
\hline $1909 / 10$ & 6 & 21 & 24 & 21 & 72 \\
\hline $1910 / 11$ & 8 & 17 & 24 & 24 & 73 \\
\hline
\end{tabular}

Źródło: ArITSK, A 581 Kraków-Rakowicka 27. Katalog glówny z wykazem klasyfikacyjnym od 1894 do 1903 r., A 582 Kraków-Rakowicka 27. Schronisko im. ks. A. Lubomirskiego. Katalog główny 1903-1911.

Każdego roku przeprowadzał w szkole wizytację okręgowy inspektor szkolny. Ze swej strony kuratoria, poprzez swoich członków, wizytowała, bez wcześniejszej zapowiedzi tak zakład jak i szkołę. W czasie takiej wizytacji zwracano uwagę na wypełnianie regulaminu dnia, funkcjonowanie szkoły, sprawę żywienia wychowanków, stan sanitarny obiektów, funkcjonowanie dyrekcji i prowadzenie ogrodu.

Klasyfikacja wyników nauczania odbywała się dwa razy w roku. Pierwsze półrocze kończyło się pod koniec stycznia. Wyniki drugiego półrocza stanowiły

109 ArITSK, A 554 Sprawozdania z czynności schroniska fundacji ks. A. Lubomirskiego za lata 1893-1949, Sprawozdanie dyrekcji za rok 1907. 
o ocenie końcowej i promocji ucznia do następnej klasy. Oprócz ocen z przedmiotów, które decydowały o promocji ucznia, każdy klasyfikowany był z obyczajów (skala ocen: chwalebne, dobre, dość dobre, naganne), pilności (wytrwała, dobra, dość dobra, mała) i porządku zewnętrznego ${ }^{110}$.

Tab. nr 5: Klasyfikacja uczniów szkoły ludowej w latach 1893-1911

\begin{tabular}{|c|c|c|c|c|c|c|}
\hline r. szk. & I-IV & bd. & db. & dst. & ndst. & $\begin{array}{c}\text { nie klasyfi- } \\
\text { kowani }\end{array}$ \\
\hline $1893 / 1894$ & 32 & 5 & 11 & 12 & 4 & - \\
\hline $1894 / 1895$ & 63 & 10 & 17 & 31 & 5 & - \\
\hline $1895 / 1896$ & 76 & 17 & 32 & 21 & 4 & - \\
\hline $1896 / 1897$ & 90 & 22 & 34 & 24 & 10 & - \\
\hline $1897 / 1898$ & 80 & 14 & 26 & 19 & 8 & 13 \\
\hline $1898 / 1899$ & 73 & $?$ & $?$ & $?$ & $?$ & $?$ \\
\hline $1899 / 1900$ & 76 & 14 & 33 & 22 & 7 & - \\
\hline $1900 / 1901$ & 69 & 12 & 22 & 25 & 7 & 3 \\
\hline $1901 / 1902$ & 67 & 12 & 25 & 23 & 7 & - \\
\hline $1902 / 1903$ & 77 & 12 & 38 & 18 & 8 & 1 \\
\hline $1903 / 1904$ & 83 & 17 & 41 & 21 & 4 & - \\
\hline $1904 / 1905$ & 80 & 20 & 29 & 22 & 9 & - \\
\hline $1905 / 1906$ & 63 & 12 & 26 & 18 & 7 & - \\
\hline $1906 / 1907$ & 90 & 11 & 41 & 27 & 10 & 1 \\
\hline $1907 / 1908$ & 79 & 9 & 35 & 26 & 9 & - \\
\hline $1908 / 1909$ & 75 & 11 & 36 & 17 & 11 & - \\
\hline $1909 / 1910$ & 72 & 10 & 36 & 13 & 13 & - \\
\hline $1910 / 1911$ & 73 & $?$ & 54 & $?$ & 10 & 7 \\
\hline
\end{tabular}

Źródło: A 581 Kraków-Rakowicka 27. Katalog główny z wykazem klasyfikacyjnym od 1894 do 1903 r., A 582 Kraków-Rakowicka 27. Schronisko im. ks. A. Lubomirskiego. Katalog główny 1903-1911, A 618 Lubomirscy. Katalog klasyfikacyjny 1896-1903.

Życie codzienne zakładu młodzieżowego urozmaicały odwiedziny ważnych osobistości duchownych i świeckich. Na zakończenie roku szkolnego 1899/1900 dnia 29 czerwca został zaproszony do odprawienia uroczystego nabożeństwa dziękczynnego ks. dr Mieczysław Barabasz, proboszcz z Baltimo-

${ }^{110}$ ArITSK, A 581 Kraków-Rakowicka 27. Katalog główny z wykazem klasyfikacyjnym od 1894 do 1903 r., A 582 Kraków-Rakowicka 27. Schronisko im. ks. A. Lubomirskiego. Katalog główny $1903-1911$. 
re, przebywajcy czasowo w Krakowie na uroczystości zorganizowanej z okazji jubileuszu Uniwersytetu Jagiellońskiego. W maju 1908 r. zakład zwiedził kard. Jan Puzyna. Podczas mszy św., odprawionej w kaplicy zakładowej, wielogłosowy chór wychowanków odśpiewał śpiewy liturgiczne i pieśni na głosy. Dnia 15 czerwca 1909 r. zwizytował zakład minister oświaty, namiestnik Galicji, sekretarz ministerialny oraz delegat namiestnictwa. Przy każdorazowych odwiedzinach orkiestra dęta odgrywała hymn ludowy i przy dźwiękach melodii polskich pieśni patriotycznych przyjmowano dostojnych gości ${ }^{11}{ }^{1}$.

Wychowankowie podlegali ścisłemu i nieustannemu nadzorowi, który sprawowało kierownictwo zakładu i personel wychowawczy. Siostry zakonne starały się zapewnić młodszym wychowankom prawdziwie macierzyńską opiekę. Starsi wychowankowie byli natomiast poddani karcącemu systemowi wy. chowawczemu, polegającemu na uprzednim zaznajomieniu podwładnych z przepisami regulaminu, a następnie na skrupulatnym i konsekwentnym egzekwowaniu go i stosowaniu odpowiednich kar w przypadku przewinienia ${ }^{112}$. Według założeń tego systemu słowa, czyny i cały sposób postępowania przełożonego winien być surowy, a nawet groźny. Dla nadania swojej władzy większego autorytetu przełożony winien rzadko pojawiać się w gronie wychowanków, przeważnie wtedy tylko, gdy zachodziła potrzeba wymierzenia kary lub zagrożenia nią. System ten, łatwy dla wychowawcy, a nawet dla niego wygodny, nadawał się raczej do wojska, lub społeczności ludzi dorosłych i starszych. Nie był on jednak właściwy w odniesieniu do młodszych chłopców o nieuformowanych jeszcze charakterach i postawach moralnych ${ }^{113}$.

\section{b) pod zarządem salezjanów}

Dzień 1 września 1911 r. był datą przełomową w dziejach krakowskiej fundacji księcia Lubomirskiego. Dotychczasowy dyrektor ks. A. Lang, pełniący tę funkcję od 18 lat, a także personel wychowawczy, składający się z sióstr szarytek w liczbie 8 oraz większość wychowawców świeckich, ustąpili z zakładu. Ich miejsce zajęli członkowie Towarzystwa św. Franciszka Salezego. Schronisko to stało się czwartą z kolei placówką, kierowaną przez zgromadzenie na terenie Galicji. Salezjanie bowiem wcześniej otwarli zakłady wychowawcze w Oświęcimiu w 1898 r., w Daszawie w 1904 r., w Przemyślu w 1907 roku ${ }^{114}$.

111 ArITSK, A 554 Sprawozdania z czynności schroniska fundacji ks. A. Lubomirskiego za lata 1893-1949, Sprawozdanie dyrekcji za rok 1900 i 1909.

112 ArITSK, T. Schronisko Lubomirskich, Sprawozdanie wizytacyjne 1893-1910. Kary stosowane: 1. pozbawienic śniadania, obiadu lub kolacji, 2. surowa nagana, 3. zamknięcie w karcerze, 4. kara cielesna w nadzwyczajnych tylko wypadkach stosowana w obecności ochmistrza (wychowawcy).

113 L. Ci a n, System zapobiegawczywy św. Jana Bosko, Warszawa 1986, s. 60-70.

114 25-lecie, s. 7-36; Pry wa czy k, dz. cyt., s. 212. 
Kontakty Polaków ze zgromadzeniem salezjańskim są bardzo wczesne, bo nawiązane zostały bezpośrednio z jego założycielem, ks. Janem Bosko. Stosunki narodowościowe, religijne, polityczne i ekonomiczno-społeczne istniejące na terenie zaborów: rosyjskiego, pruskiego i austriackiego, stały się w ostatnim ćwierćwieczu XIX stulecia przyczyną wychodźctwa politycznego i ekonomicznego (emigracja zarobkowa) ${ }^{115}$. Niektórzy z emigrantów zawitali do zakładów salezjańskich, zwłaszcza do Turynu, gdzie w latach 1865-1885 kończyli szkołę. Liczba 300 chłopców, po większej części ze Śląska i Wielkopolski, przebywająca w różnych zakładach salezjańskich w Italii, spowodowała, że w 1894 r. otwarto osobny zakład wychowawczy w Lombriasco, tylko dla Polaków ${ }^{116}$. W 1897 r. do zgromadzenia należało już 3 księży, 20 koadiutorów i prawie 100 kandydatów do kapłaństwa polskiego pochodzenia.

O żywym zainteresowaniu działalnością ks. J. Bosko wśród polskiej magnaterii świadczy zaproszenie go w 1883 r. do Hotelu Lambert przez Wladysława Czartoryskiego, syna księcia Adama, gdzie skupiało się życie polityczne emigracji polskiej. Książę Władysław, znając trudną sytuację mas robotniczochłopskich w kraju, a także stan materialny i moralny młodzieży polskiej, zwłaszcza ubogich sierot i bezdomnych, chciał, aby dla uzdrowienia sytuacji, salezjanie otworzyli swe zakłady wychowawcze w ojczyźnie, wprowadzając do nich swój system wychowawczy. Swoim zaangażowaniem sprawił, że już w roku następnym 28 lutego na posiedzeniu kapituły wyższej zgromadzenia salezjańskiego ${ }^{117}$, rozpatrywano możliwość wysłania salezjanów w głąb Rosji i na ziemie polskie ${ }^{118}$.

Zainteresowanie w Polsce osobą ks. Bosko i jego działalnością było tak żywe, że zaistniała konieczność wydania w języku polskim pozycji książkowych, traktujących o jego życiu i dziele. Pierwszy żywot wydano w Warszawie w 1886 r., następne ukazały się we Lwowie, Poznaniu i Krakowie ${ }^{119}$. Z księ-

115 F. B uj ak, Galicja, t. 2, Lwów 1910, s. 284-288; S. Ki e nie w i cz, Czyn Polski w dobie Wiosny Ludów, Warszawa 1948, s. 4-6; te nż e, Galicja w dobie autonomicznej, Wrocław 1952, s. 13-15.

116 Pel cz a r, dz. cyt.. s. 204; A. Ś wi d a, Droga do samodzielności polskiej prowincji salezjańskiej, Warszawa 1990, s. 53-56; Z. K uza k, Poczatki Towarzystwa Salezjańskiego w Polsce, "Nostra", 29 (1974) nr 1, s. 14-16.

117 „Co dotyczy zarządu wewnętrznego, najwyższa władza całego Towarzystwa jest powierzona zwyczajnie Przełożonemu Generalnemu i jego Radzie, zwanej Kapitułą Wyższą, a składającej się z Prefekta, Kicrownika Duchownego, Ekonoma i trzech Radców, nadzwyczajnie zaś Kapitule Generalnej". Ustawy $i$ Regulaminy, art. 50 (Ust.).

118 J. B. Le y m o y ne, Memorie Biografice, t. 18, Torino 1937, s. 347.

${ }^{119}$ K. E s p in a y, Ksiądz Bosko, Lwów 1886; Ksiądz Jan Bosko Opiekun i Nauczyciel sierot, Warszawa 1886; L. Nö el, Ksiadz. Jan Bosko jego żywot i czyny podlug różnych źródet opracowane, Poznań 1887; M. O. S., Ksiq̨dz Jan Bosko, Kraków 1889. 
dzem Bosko korespondowali duchowni i świeccy, wyrażając potrzebę przeszczepienia dzieła salezjańskiego na grunt polski ${ }^{120}$.

Salezjanie, również ze swej strony, urabiali lokalną opinię publiczną na terenach Polski, na temat przeszczepienia swego zakonu najpierw do Galicji. W tym celu w Turynie od 1897 r. wydawano miesięcznik „Wiadomości Salezjańskie" w języku polskim. Cieszyły się one dużą poczytnością, tak że po trzech latach osiągnęły nakład 55 tys. egzemplarzy ${ }^{121}$.

Jednym z korespondentów ks. Bosko był ks. Andrzej Knycz, proboszcz i dziekan oświęcimski. Chcąc okazać wdzięczność za wyleczenie go z choroby przez ks. Bosko, za przyczyną Matki Bożej Wspomożenia Wiernych, postanowił osiedlić salezjanów w swej parafii ${ }^{22}$. Sprawa ta szła dosyć powoli, głównie $\mathrm{z}$ braku polskiego personelu zakonnego. Duże nadzieje pokładano w księciu Auguście Czartoryskim, synu Władysława, który wstąpił do zgromadzenia w 1887 r. Przełożeni wyżsi zgromadzenia widzieli w nim przyszłego przełożonego i pioniera salezjańskiej misji młodzieżowej w Polsce ${ }^{123}$. Niestety ks. August nie doczekał tej chwili, gdyż zmarl 8 kwietnia $1893 \mathrm{r}$. w niespełna rok po otrzymaniu święceń kapłańskich. W tej sytuacji bp krakowski Jan Puzyna, zachęcony sugestiami prałata A. Knycza, w listopadzie 1895 r. zwrócił się do ks. Michała Rua, Przełożonego Generalnego zgromadzenia, prosząc o przysłanie salezjanów do swojej diecezji. Ksiądz Rua poprosił o cztery lata zwłoki, celem przygotowania polskiej ekipy. Ordynariusz krakowski, mimo to, w lipcu 1897 r. ponowił swą prośbę, nalegając by przysłał „conajmniej dwóch współbraci celem ufundowania domu". Starania te sfinalizowano 15 sierpnia 1898 r. osiedleniem salezjanów w Oświęcimiu ${ }^{124}$.

${ }^{120}$ Ks. Władyslaw Czencz, zamieszkały w Krakowie przy ul. Kopernika 26, wysłał 24 grudnia 1887 r. list do ks. Bosko, zamieszczony w „Misjach Katolickich”, 8 (1888) nr 1, s. 31. W obszernym i wymownym piśmie błagał o przeszczepienie jego dzieła wychowawczego na tcren Polski. Znicz życia Wielkiego Wychowawcy już dogasał, a na odpowiedź pozytywną nie było danych.

121 25-lecie, s. 8; S. Sty rna, Zgromadzenie Salezjańskie w Polsce w poszukiwaniu formy odpowiedzi na potrzeby wychowawcze i duszpasterskie w latach 1898-1974, w: 75 lat ..., s. 12.

122 Slós a r czyk, dz. cyt., t. l, s. 5.

${ }^{123}$ 25-lecie, s. 9; M. K a c z m a r czy k, Czartoryski August Franciszek, w: Hagiografia polska, t. 1, Poznań 1971, s. 274-280.

${ }^{124}$ AKMKr, 202 Salezjanie, Ks. A. Knycza do Książęco-Biskupiego Konsystorza w Krakowie z 27 X 1895 r. Kard. Puzyna do ks. Michała Rua 9 VI 1897 r. pisał: „dalsze oczekiwanie, choćby tylko przez krótki czas, przyprawiłoby tutejszą ludność o szkody moralne bardzo wielkie. Dlatego powtarzam moją prośbę o przysłanic mi conajmniej dwóch współbraci Zgromadzenia w celu ufundowania domu [...] proszę, by to stało się jak najprędzej i bez zwłoki [...] zło szerzy się $\mathrm{z}$ nieprawdopodobną gwałtownością. Niech Ojciec nie odmawia mi pomocy w moich kłopotach: jako biskup muszę zdać sprawę z tak wielkiej liczby dusz pozostających w niebezpieczeństwie potępienia". 
Zakład salezjański w Oświęcimiu z roku na rok nabierał rozgłosu jako wzorowa placówka wychowawczo-rzemieślnicza, nie tylko w zachodniej Galicji, ale i na pobliskich terenach Śląska pruskiego. Dobre wyniki, jakie osiągnęli salezjanie oświęcimscy w pracy pedagogiczno-dydaktycznej $z$ jednej strony, przy równoczesnej inercji wychowawczej w schronjsku Lubomirskich (młodzież starsza po opuszczeniu fundacji dość często odchodziła daleko od moralności chrześcijańskiej) z drugiej strony, skłoniła zarówno kuratorię, a także kurię biskupią do powierzenia salezjanom zarządu schroniska ${ }^{125}$. Sprawę tę popierał szczególnie ks. bp Anatol Nowak, sufragan krakowski. Kuria, sprawująca duchową opiekę nad zakładem, rozpoczęła pertraktacje z ówczesnym ks. inspektorem Emanuelem Manassero. Postanowiono, aby dla zapoznania się z działalnością instytucji księcia Lubomirskiego, skierować salezjanina na stanowisko kapelana w roku szkolnym 1905/1906.

Kapelanem i katechetą został mianowany neoprezbiter ks. August Hlond, późniejszy kardynał i prymas Polski. Odprawiał on codziennie mszę św. dla wychowanków. Rano sprawdzał porządek w sypialniach, a wieczorem obecny był na modlitwach. Według potrzeby i uznania dyrekcji (jako wykształcony muzyk) udzielał nauki śpiewu lub uczył innego przedmiotu u terminatorów, a ponadto pomagał chłopcom w przygotowaniu się do lekcji. Jako katecheta uczył religii wszystkich wychowanków, według stałego rozkładu. Do jego obowiązków należało jednocześnie zasięganie dwa razy w miesiącu informacji u mistrzów o terminatorach, odbywających u nich praktykę ${ }^{126}$.

Nie była to praca łatwa. Można powiedzieć, że ilu terminatorów, tyle było rzemiosł rozsianych w różnych punktach Krakowa. Niektórzy chodzili nawet do Podgórza ${ }^{127}$. W 1905 r., na 145 wychowanków będących w zakładzie, po odliczeniu pierwszego oddziału w liczbie 32, reszta pobierała praktykę w 19 zawodach $^{128}$. Oddziaływanie nie zawsze wzorowych mistrzów lub czeladni-

${ }^{12.5}$ ArITSK, T. Lubomirscy. Sprawa przejęcia zakladu przed I i po I wojnie światowej 19091924, Ks. Emanuel Manassero, dyrektor zakładu oświęcimskiego do c.k. Namiestnictwa z 13 I 1903 r., w którym czytamy: „Zachęcony przez rodzinę Fundatora istniejącego w Krakowie zakładu im. Lubomirskich, ośmielam się przedstawić Wysokicmu c.k. Namiestnictwu projekt [...]". Dodać trzeba, że członek rodziny Fundatora należał do kuratorii, kompetentnej do decydowania o wszelkich sprawach związanych z zakładem.

${ }^{126}$ AKMKr, 202 Salezjanie, Książęco-Biskupi Konsystorz do prowincjała ks. E. Manassero 6 XI 1905 r. potwierdzający ks. Hlonda na stanowisko katechety i kapelana w zakładzie; ArITSK, T. Lubomirscy. Przejęcie zakładu przed I i po I wojnie światowej, Kuratoria do Zgromadzenia Salezjańskiego w Oświęcimiu 24 X 1905 r.

${ }^{127}$ ArTTSK, B 1503 Kraków-Lubomirscy. Kronika, Kronika Lubomirskich (1905-1906).

${ }^{128}$ Zawody, w których chłopcy pobierali praktykę: szkoła przemysłowa, ogrodnicy, szkoła kupiecka, ślusarze, tokarze, mechanicy, automonterzy, blacharze, stolarze, drukarze, rytownicy, jubilerzy, praktykanci handlowi i kucharze. Stan wychowanków w bursie, „Echo Bursy”, 2 (1927) nr 1-2, s. 6. 
ków na młodych praktykantów, połączone z agitacją socjalistyczną, sprawiało, że chłopcy pod przeróżnymi pretekstami chcieli uwolnić się od nadzoru wychowawczego ${ }^{129}$. Młody neoprezbiter wspaniale wywiązywał się ze swych obowiązków. Jako zamiłowany muzyk rozbudził wśród chłopców zapał do śpiewu. Jego kazania, krótkie i treściowe, były interesujące i „morowe”, jak je określali wychowankowie. Był dla nich nie tylko mężem opatrznościowym, podtrzymującym ich moralnie na duchu, ale także materialnie, według swej możności i skromnej pensji kapelana, wynoszącej 1600 koron rocznie $^{130}$. Do tych obowiązków doszły i nowe, kiedy Książęco-Biskupi Konsystorz diecezji krakowskiej zamianował go 4 października 1906 r. nauczycielem religii w szkole przemysłowej uzupełniającej przy ul. Lubomirskich w Krakowie $^{131}$. Po dwuletniej owocnej pracy w zakładzie Lubomirskich, opuszczał tę placówkę żegnany przez młodzież, na ogół obojętną, głośnym płaczem ${ }^{132}$.

Jego miejsce zajął dotychczasowy radca szkolny ${ }^{133}$ zakładu oświęcimskiego ks. Stanisław Pływaczyk. Objął on dodatkowo naukę religii w pobliskiej szkole uzupełniającej, do której uczęszczała większość terminatorów z zakładu. Praca ta była wyczerpująca obustronnie. Młodzież, zmęczona praktyką w ciągu dnia, początkowo niechętnie uczęszczała wieczorem na naukę $w$ tejże szkole, gdzie zajęcia trwały od godziny 18 do 21 . Władze szkolne wszakże uzależnity wydanie świadectwa czeladniczego od ukończenia szkoły ${ }^{134}$.

Wobec nieprzychylnej postawy kuratorii odnośnie powierzenia zarządu schroniska salezjanom, ksiądz inspektor z końcem roku szkolnego 1907/1908 wycofał ks. S. Pływaczyka z zakładu. Na prośbę jednak kurii biskupiej wyznaczył tymczasowo na jego miejsce ks. Jerzego Kalinowskiego i ks. Jana Szlach$\mathrm{te}^{135}$. Ich odejście uświadomiło zarządowi placówki, pozytywne skutki młodzieżowej działalności salezjańskiej w schronisku.

${ }^{129}$ ArITSK, B 1503 Kraków-Lubomirscy. Kronika, Kronika Lubomirskich (1905) Pływa czy k, dz. cyt., s. 223.

${ }^{130}$ AKMKr, 202 Salezjanie, Kuratoria fundacji do ks. Hlonda w Oświęcimiu 4 X 1906 r.

131 AKMKr, 202 Salezjanie, Konsystorz Książęco-Biskupi do kapelana schroniska Hlonda 4 X $1906 \mathrm{r}$.

${ }^{132}$ W lipcu 1907 r. przełożeni mianowali go dyrektorem nowo otwartej placówki w Przemyślu na Zasaniu. ArITSK, B 1503 Kraków-Lubomirscy. Kronika, Kronika Lubomirskich(1905-1906); Świ da, Towarzystwo Salezjaniskie, s. 83.

133 „Zadaniem radcy szkolnego jest dopilnować, w porozumieniu z dyrektorem, aby szkoła, nie wyłączając lekcji śpiewu, funkcjonowała należycie. Dlatego jest konieczne, aby znał rozporządzenie władz, odnoszące się do szkól jemu powierzonych. On czuwa nad karnością wychowanków", Ustawy i Regulaminy, art. 191, 192 (Reg.).

${ }^{134}$ ArITSK, B 1503 Kraków-Lubomirscy. Kronika, Kronika Lubomirskich (1906).

135 Pływ a czyk, dz. cyt., s. 224. 
Sprawa przejęcia zakładu przewlekała się z różnych przyczyn. Salezjanie nie mogli podjąć pracy w schronisku jednocześnie z siostrami miłosierdzia, gdyż było to sprzeczne $\mathrm{z}$ aktem fundacyjnym i prawem kościelnym. Kuratoria, strzegąca czujnie funduszu zakładowego, nie chciała wyrazić zgody na przebudowę zakładu, której żądali salezjanie. Pierwszą trudność, dotyczącą aktu fundacyjnego, usunęło c.k. Ministerstwo, zamieniając dawne brzmienie paragrafu V: „Przy poruczaniu nadzoru w zakładzie należy dać pierwszeństwo zakonnicom” na: „Do kierownictwa zakładu pod względem wychowawczonaukowym i administracyjnym są ustanowieni katoliccy duchowni zakonni" ${ }^{136}$. Drugą przeszkodę, jaką stanowiła obecność sióstr miłosierdzia, rozwiązały one same. Nieoczekiwanie bowiem zaproponowały natychmiastowe odejście bez żadnych zobowiązań ${ }^{137}$.

Wznowione pertraktacje doprowadziły 12 lipca 1911 r. do oddania przez kuratorię zakładu salezjanom. Podjęli oni pracę w zakładzie na podstawie umowy zawartej między fundacją księcia Lubomirskiego, reprezentowaną przez delegata namiestnictwa i przewodniczącego kuratorii Adama Federowicza $z$ jednej, a inspektorem prowincji św. Aniołów Stróżów, ks. E. Manassero z drugiej strony, którego reprezentował ks. Jan Świerc. Umowy tej nie mogło zawrzeć w tym czasie zgromadzenie, ponieważ nie posiadało jeszcze egzempcji papieskiej i nie było zatwierdzone na terenie Galicji ${ }^{138}$. Przełożeni galicyjscy zabiegali o zatwierdzenie władz państwowych. Zatwierdzenie to

${ }^{136}$ ArITSK, T. Zakład księcia Aleksandra Lubomirskiego w Krakowie, Akt fundacyjny, par. 5. Pierwotne brzmienie aktu fundacyjnego: „Przy poruczaniu nadzoru w zakładzie należy dać pierwszeństwo zakonnicom". Fundacja schroniska we Lwowie zawiadomiła kuratorię, że, powolując się na jej pismo z 28 XII 1902 r., c.k. Ministerstwo Spraw Wewnętrznych reskryptem z 19 maja 1910 r. zezwoliło na następującą zmianę brzmienia $V$ paragrafu: „Do kierownictwa zakładu pod względem wychowawczo-naukowym i administracyjnym są ustanowieni katoliccy duchowni zakonni. Do nich też należeć będzie kierownictwo religijno-wychowawcze wychowanków"; AKMKr, 202 Salezjanie, Bp A. Nowak kuratorii kilkakrotnie proponował powierzenie zakładu salezjanom, ze względu na jego dobro. Nie podzielał opinii kuratorii, by pracowały w zakładzie dwa zgromadzenia zakonne: męskie i żeńskie. Świadczy o tym pismo kurii do kuratorii z 6 VII $1909 \mathrm{r}$.

${ }^{137}$ ASMK, T. Schronisko Lubomirskich, Wizytatorka s. J. Zaleska do kuratorii 12 i 25 V 1909 r., Zaleska do Książęco-Biskupiego Konsystorza 31 V 1909 r.

${ }^{138}$ AKMKI, 202 Salezjanie, Zapytanie c.k. Prokuratorii Skarbu do Konsystorza, czy zgromadzenie salezjańskie jest uznane przez władze kościelne i administracyjne, Lwów $19 \mathrm{~V} 1907$ r., Manassero do Konsystorza Biskupiego 25 V 1907 r. Warto nadmienić, że zgromadzenie salezjańskie zostało zatwierdzone przez Stolicę Apostolską 3 IV 1874 r. Prowincja św. Aniołów Stróżów, do której naleźały domy w: Oświęcimiu, Daszawie i Przemyślu, została zatwierdzona dekretem Stolicy Apostolskiej z 14 X 1905 r. Natomiast brak było dotychczas zatwierdzenia ze strony wladz austriackich. J. K r a w i e c, Towarzystwo Sw. Franciszka Salezego oraz jego organizacja w Polsce, Lublin 1964, s. 175, mps; A. Świ d a, Droga do samodzielności polskiej prowincji salezjańskiej, Warszawa 1990, s. $85,105$. 
uzyskano w rok później 27 czerwca 1912 roku $^{139}$. Umowę z dnia 12 lipca 1911 r. zatwierdziło namiestnictwo we Lwowie 4 sierpnia 1911 roku ${ }^{140}$. W myśl umowy, salezjanie przejęli od 1 września wszystkie prawa i obowiązki administracyjne $\mathrm{i}$ wychowawcze według brzmienia aktu fundacyjnego i statutu organizacyjnego na przeciąg 15 lat, tj. do 30 czerwca 1926 r., o ile nie zostanie wypowiedziana przez którąkolwiek ze stron na dwa lata wcześniej ${ }^{141}$.

Salezjanie zrzekli się dobrowolnie na rzecz zakładu osobistej pensji miesięcznej, by podnieść liczbę wychowanków, pod warunkiem, że przejmą ogród w swoją administrację. Kuratoria zaakceptowała tę propozycję. Dotychczasowy dyrektor ks. A. Lang przeszedł na emeryturę, którą miał mu wypłacać zakład, zgodnie z ustaleniem umowy. Jego miejsce zajął ks. Jan Świerc, dotychczasowy dyrektor zakładu oświęcimskiego ${ }^{142}$. Nowy dyrektor otrzymał do pomocy dwóch księży: Leona Kaszycę (na kapelana zakładu) i Jana Sikorę. Miał on zostać radcą szkolnym i nauczycielem klasy trzeciej szkoły ludowej. Przybyły kleryk Jan Siara pełnił funkcję asystenta. Ponadto koad. Antoni Skwarkowski i kucharz Sorter pełnili funkcje pomocnicze. Dnia 21 września przyjechał drugi asystent kleryk Wojciech Pływaczyk, a pod koniec miesiąca ks. Stanisław Krygier jako radca zakładu, asystent terminatorów i nauczyciel śpiewu. Zwolniony z obowiązku tymczasowego radcy ks. Sikora zastępował katechetę w szkole wydziałowej męskiej św. Floriana. Na miejsce ks. Krygiera, przeznaczonego do Przemyśla, przybył i przejął obowiązki radcy diakon Józef Loska, od 28 listopada tegoż roku. Przybycie w kwietniu 1912 r. koad. Antoniego Ulmana skompletowało salezjański personel w schronisku fundacji im. księcia A. Lubomirskiego w Krakowie przy ul. Rakowickiej $27^{143}$.

${ }^{139}$ Dopiero ks. Augustowi Hlondowi pracującemu we Wiedniu udało się po dłuższych staraniach uzyskać zezwolenie na osiedlenie się salezjanów w manarchii, czyli rządowe zezwolenie na zakładanie swoich domów uzyskali salezjanie na mocy decyzji cesarza Franciszka Józefa I, który biorąc pod uwagę prośby ordynariuszów diecezji lublańskiej i triesteńskiej, dnia 27 VII $1912 \mathrm{r}$. wyraził zgodę na sprowadzenie salezjanów do wyżej wymienionych diecezji. Stało się to dopiero po 25 latach ich pracy $w$ państwie austriackim. Pierwszy dom otwarli salezjanie $w$ Trydencie w $1887 \mathrm{r}$. Rząd austriacki niechętny był zgromadzeniu włoskiemu (salezjanom). Nie mógł długo zapomnieć zabrania przez zjednoczone Włochy północnych prowincji Italii, należących przez długie lata do monarchii Austro-Węgierskiej. K r a w i e c, dz. cyt., s. 183, 184.

${ }^{140}$ AKMKr, 202 Salezjanie, Kuratoria do Kurii donosi o zatwierdzeniu przez c.k. Namiestnictwo Umowy z dnia 4 VIII 1911 r., Kraków 7 VIII 1911 r.

141 ArITSK, Umowa, § 10.

${ }^{142}$ ArITSK, B 1503 Kraków-Lubomirscy. Kronika, Kronika Lubomirskich (1 IX 1911 - 18 IV 1912).

${ }^{143}$ ArTSK, B 1503 Kraków-Lubomirscy. Kronika, Kronika Lubomirskich (1 IX 1911 - 18 IV 1912) 
Tab, nr 6: Uczniowie szkoły ludowej w latach 1911-1914

\begin{tabular}{|c|c|c|c|c|c|}
\hline r. szk. & I & II & III & IV & razem \\
\hline $1911 / 1912$ & 13 & 22 & 20 & 24 & 79 \\
\hline $1912 / 1913$ & 7 & 23 & 33 & 23 & 86 \\
\hline $1913 / 1914$ & 4 & 11 & 39 & 33 & 87 \\
\hline
\end{tabular}

Źródło: ArITSK, A 617 Kraków-Rakowicka 27. Schronisko im. ks. A. Lubomirskiego. Katalog klasowy 1911-1914.

Tab. nr 7: Wyniki nauczania w szkole ludowej w latach 1911-1914

\begin{tabular}{|c|c|c|c|c|c|}
\hline r. szk. & I-IV & promowani & $\begin{array}{c}\text { nie promo- } \\
\text { wani }\end{array}$ & odeszli & $\begin{array}{c}\text { nie klasyfiko- } \\
\text { wani }\end{array}$ \\
\hline $1911 / 1912$ & 79 & 65 & 12 & 1 & 1 \\
\hline $1912 / 1913$ & 86 & 75 & 10 & 1 & - \\
\hline $1913 / 1914$ & 87 & 57 & 22 & 6 & 2 \\
\hline
\end{tabular}

Źródło: ArITSK, A 617 Kraków-Rakowicka 27. Schronisko im. ks. A. Lubomirskiego. Katalog klasowy 1911-1914.

Tab. nr 8: Nauczyciele w szkole ludowej przy ul. Rakowickiej 27 w latach 1911-1914

\begin{tabular}{|c|c|c|c|}
\hline r. szk. & klasy & $\begin{array}{c}\text { gospodarz klasy } \\
\text { (wychowawca) }\end{array}$ & nauczyciel religii \\
\hline $1911 / 1912$ & I, II & Antoni Glodt & ks. Leon Kaszyca \\
& III & Adan Kosicki & \\
IV & Stanisław Lang & \\
\hline $1912 / 1913$ & I, II & Antoni Glodt & \\
& III & Adam Kosicki & \\
\hline $1913 / 1914$ & IV & Stanisław Lang & ks. Józef Heintzel \\
& III & Antoni Glodt & \\
& IV & Adam Kosicki & \\
\hline
\end{tabular}

Źródło: ArITSK, A 617 Kraków-Rakowicka 27. Schronisko inı ks. A. Lubomirskiego. Katalog klasowy 1911-1914.

Salezjanie zwiększyli liczbę chłopców na początku roku szkolnego 1911/ 1912 z 145 na 150 . W latach następnych utrzymywali dolną granicę 160 , według zobowiązań, zawartych w umowie $\mathrm{z}$ kuratorią $\mathrm{w} 1911 \mathrm{r}$. W roku szkolnym 1911/1912 było 162 wychowanków, a w 1913/1914 już 181. Salezjanie uzyskali niezależność od władz zwierzchnich fundacji w stosowaniu metod wychowawczych. Zmienili też system wychowawczy karcący na system zapobiegawczy (uprzedzający), wypracowany przez założyciela zgromadzenia ks. Bosko. Swieckie siły pedagogiczne zastąpili własnym personelem zakonnym. Pozo- 
stał jedynie wieloletni nauczyciel klas czwartych Stanisław Lang, a całe życie zakładu podporządkowali zasadom systemu wychowawczego opracowanego i praktykowanego w pracy przez ks. Bosko ${ }^{144}$.

Tab. nr 9: Liczba wyzwolonych terminatorów w latach 1911-1914

\begin{tabular}{|r|c|c|c|c|}
\hline r. szk. & ogółem & terminatorzy & wyzwoleni & zawody \\
\hline $1911 / 1912$ & 150 & $?$ & 2 & $?$ \\
\hline $1912 / 1913$ & 162 & 37 & $?$ & 16 \\
\hline $1913 / 1914$ & 181 & 25 & 11 & 5 \\
\hline
\end{tabular}

Źródło: ArITSK, A 554 Sprawozdania z czynności schroniska fundacji ks. A. Lubomirskiego za lata 1893-1949, Sprawozdanie dyrekcji za rok 1912, 1913.

Przez opracowanie i stosowanie we wszystkich zakładach salezjańskich tzw. systemu uprzedzającego, stał się ks. Bosko pionierem chrześcijaskiego stylu wychowania młodzieży. W systemie tym występowała zasada prymatu wychowanka tj. pełna podmiotowość w procesie kształtowania jego osobowości. System uprzedzający (prewencyjny), stosowany przez ks. Bosko, wymagał od wychowawcy troskliwego i uważnego zainteresowania się osobą wychowanka. Rozum, religia, życzliwość i miłość, apelując do sumienia młodego człowieka, oczekiwały od niego wolnej i bezpośredniej reakcji na ten głos. Styl wychowania ks. Bosko silnie oddziaływał na osobowość wychowanka i uwzględniał jego indywidualnośćc ${ }^{145}$.

Ta chrześcijańska koncepcja zakładała, że w trakcie wychowania zachodzi proces doskonalenia i wzrostu, przebiegający od tego co gorsze do tego co lepsze, aż do zupełnej dojrzałości duchowej i psychicznej. U ks. Bosko wszelkie dążenia ludzkie przenikały cały jego system wychowawczy: nauka a więc szukanie prawdy; wesołość, sport, radość, podziw przyrody w czasie wycieczek, czyli szukanie, odkrywanie wiedzy i piękna; wreszcie uczciwość, prawdomówność, szczerość. Wszystkie te elementy były nieustannie stosowane w jego pedagogii. Obecność wychowawcy w procesie wychowania - według ks. Bosko - była konieczna, gdyż wychowanek nie może działać całkowicie samodzielnie. Powinien opierać się na wskazówkach asystenta ${ }^{146}$, który obowiązany

144 ArITSK, B 1503/Kraków-Lubomirscy. Kronika, Kronika Lubomirskich (1 IX 1911 - 24 V 1913).

${ }^{145}$ M. K u bry c h t, Poznajemy ks. Bosko i jego system wychowawczy, PS, 16 (1932) nr 2, s. 38-40.

${ }^{146}$ Pod nazwą asystenta rozumie się $w$ zakladach salezjańskich wychowawców $z$ urzędu przebywających stale wśród wychowanków w kaplicy, jadalni, na podwórzu, na przechadzce itd. W ścisłym znaczeniu asystentami są klerycy na tzw. trzyletniej praktyce wychowawczej, poprzedzającej studia teologiczne; w szerszym tego słowa znaczeniu i wg myśli ks. Bosko asystentem jest każdy salezjanin. Ustawy i Regulaminy, art. 88 (Reg.). 
jest stworzyć odpowiednie warunki, korzystne dla rozwoju osobowości swoich podwładnych. Dlatego też zwracał on uwagę na życzliwy stosunek do chłopców. Odnośnie do osoby wychowawcy tak pisat: „Wychowawca niech się stara, by go wychowankowie polubili, jeśli chce, żeby się go bali [...] Przełożony niech będzie ich ojcem i przyjacielem"147.

Co do kar mówił ks. Bosko: „Gdzie możliwe, kar żadnych nie używać [...] u chłopców to jest karą, co się za karę uważa. Na niejednym wejrzenie z wyrazem wyrzutu wywiera większe wrażenie, niżby to sprawil wymierzony policzek. Pochwała za dobry uczynek, nagana za niedbalstwo to już wielka nagroda lub kara. $Z$ wyjątkiem bardzo rzadkich wypadków, nie należy nigdy udzielać nagany publicznie, lecz na osobności, używając wielkiej roztropności i cierpliwości, by wychowanek uznał swój błąd w świetle rozumu i wiary [...] Jakichkolwiek uderzeń [...] i innych podobnych kar powinno się stanowczo unikać, gdyż zabronione są prawem cywilnym, rozdrażniają chłopców i poniżają wychowawców"148.

Salezjanie, podejmując pracę w schronisku, przejęli jego dotychczasowe formy pracy. Na bazie zakładowego ogrodu w roku szkolnym 1911/1912 zorganizowali szkołę ogrodniczo-rolniczą. Jej inicjatorem był Stanisław Szarek, kierownik ogrodu oraz dyrektor szkoły w dzielnicy Kraków-Dąbie. W szkole nauka praktyczna odbywała się w miesiącach letnich, a przedmiotów teoretycznych uczyli się uczniowie jesienią i zimą. Pilniejszym uczniom za pracę w ogrodzie dyrekcja przyznawała drobne nagrody pieniężne, które lokowano im na książeczkach kasy oszczędnościowej ${ }^{149}$.

$\mathrm{Z}$ upływem pierwszego roku szkolnego (pod zarządem salezjanów), pod koniec czerwca 1912 r. 23 uczniów klasy IV wewnętrznej szkoły ludowej złożyło egzamin w miejskiej szkole wydziałowej św. Mikołaja z dobrym wynikiem i otrzymali świadectwa. Uczniów poniżej 14 roku życia zapisano do miejskich szkół wieczorowych, gdzie zdobywali konieczne przy wyzwolinach świadectwa $\mathrm{z}$ dokształcania.

Zaprowadzenie na codzień karności wymagało znacznego wysiłku od personelu wychowawczo-dydaktycznego. Celem większej kontroli oraz mobilizacji wychowanków do poprawnego zachowania się tak między sobą jak $\mathrm{i}$ w stosunku do przełożonych, zaprowadzono klasyfikację z zachowania (tzw. obserwacje) i pilności w nauce co dwa tygodnie. Salezjanie szczególnie preferowali rekreację na powietrzu i uprawianie dyscyplin sportowych. W nie-

147 Ustawy i Regulaminy, art. 101 (Reg.); K ubry ch t, Poznajemy ks. Bosko i jego system wychowawczy, PS, 16 (1932) nr 3, s. 71.

${ }^{148}$ Ustawy i Regulaminy, art. 101 (Reg.).

149 ArITSK, A 554 Sprawozdania z czynności schroniska fundacji im. ks. A. Lubomirskiego za lata 1893-1949, Sprawozdanie kierownika ogrodu fundacji Lubomirskich w Krakowie od 1 I 31 XII 1913 r., Sprawozdanie dyrekcji za rok 1912, 1913. 
dziele i święta odbywali $z$ wychowankami wycieczki poza zakład, tzw. przechadzki. Istotną rolę w wychowaniu odgrywały przygotowywane przedstawienia teatralne i wieczorki deklamacyjno-muzyczne. Inauguracją tego typu pracy kulturalnej było odegranie przygotowanego $z$ wychowankami melodramatu pt. "Godzina wakacji" na zakończenie roku szkolnego 1912/1913 ${ }^{150}$.

Mimo wysiłków i inicjatyw wychowawczych ze strony personelu miały miejsce wśród wychowanków wykroczenia, za które karano stosownie do winy. Z zasady wykluczone były wszelkie kary cielesne i upokarzające. Tylko wyjątkowo dyrekcja pozwalała na kary cielesne „wobec chłopców krnąbrnych i zuchwałych, którzy żadnego innego wędzidła nie uznają"

Początkowo chłopcy nieufnie odnosili się do nowych przełożonych. Przyszłość zapowiadała się niepewnie, zważywszy że salezjanie nie obejmowali nowo otwartego zakładu lecz placówkę ze swoją kilkunastoletnią historią i własną tradycją. Kronikarz tamtych lat ukazuje dobitnie ówczesne nastroje: „Pierwszy dzień upłynął jak w cudzym domu. Najważniejszą dla każdego rzeczą było zapoznać się z ubikacjami, drugą niemniej ważną zaopatrzenie się w gruby pęk kluczy. Należy bowiem wiedzieć, że wszystkie drzwi w zakładzie zamykano, a czyniono to dlatego, aby chłopcy z jednego oddziału na drugi nie przechodzili",152.

Zachowanie wychowanków było prowokacyjne. Powtarzali nierzadko, że „oni tu panami”. Otaczali wychowawców kołem nie z życzliwości lecz w celu dokładnego „oszacowania osobnika” i wyrobienia sobie o nim odpowieniej opinii. „Rozmowy ich - ciągnie annalista - ogromną głupotą były nacechowane. Najważniejszym tematem ich rozmów było jedzenie: co dobre, co złe, chleb, kiełbasa etc. Inne ich mowy również były bez związku. Widać było, że silą się na koncepty ale tak głupio i niezręcznie. Zwietrzywszy, że nie zdołają wziąć górę, że ich żarty i dowcipy bywają wyśmiane i lekceważone i że wokoło nich zaczyna się tworzyć jakaś inna atmosfera, poczęli pokątnie między sobą narzekać na salezjanów, że dają im mało jeść, że muszą cierpieć głód itd., mimo że niczego im nie ujęto"153.

W drugim miesiącu administracji salezjańskiej powoli chłopcy przyzwyczajali się do nowego porządku. Poważne trudności były z zaprowadzeniem dyscypliny u terminatorów. Przybyły z końcem listopada 1911 r. diak. Józef Loska na stanowisko radcy zakładu podszedł nieco inaczej do swoich obowiązków i zaprowadzenia dyscypliny niż jego poprzednik ks. Stanisław Krygier. Chłopcy, przyzwyczajeni do systemu karcącego, łącznie z karami cielesnymi, do-

${ }^{150}$ ArITSK, A 554 Sprawozdanie z czynności schroniska fundacji im. ks. A. Lubomirskiego za lata 1893-1949, Sprawozdanie dyrekcji za rok 1913.

151 Tamże, Sprawozdanie dyrekcji za rok 1913.

${ }^{152}$ ArITSK, B 1503 Kraków-Lubomirscy. Kronika, Kronika Lubomirskich (1 IX 1911).

153 Tamże (1 IX - 15 X 1911). 
świadczyli od nowego radcy tej samej metody wychowawczej. Terminatorzy, widząc przed sobą przewagę siły, doprowadzili do buntu. Wówczas usunięto z zakładu kilku prowodyrów, a atmosfera w zakładzie powoli się poprawiała ${ }^{154}$.

W zakładzie przywrócono codzienną mszę św. dla wychowanków. W późniejszym czasie byli oni zobowiązani do uczestnictwa w drugiej mszy św. w niedziele i święta. Na Boże Narodzenie 1911 r. 23 uczniów z I klasy szkoły ludowej przystąpiło do I Komunii św. Odegrano także Jasełka Bożonarodzeniowe, w wykonaniu wychowanków. Dnia 7 stycznia 1912 r. w kaplicy zakładowej odbyła się liturgia święceń kapłańskich radcy zakładu diakona Józefa Loski, której przewodniczył bp Anatol Nowak ${ }^{155}$.

W latach międzywojennych, w czasie nieszporów niedzielnych, dyrektor zakładu lub inny z przełożonych wygłaszali do wychowanków tzw. nauki katechizmowe. Jednak praktyka ta nie utrzymała się długo i została zaniechana. Wizytujący placówkę inspektor ks. Cieślar w 1938 r. polecał wprowadzenie tychże nauk i nieszporów w dni świąteczne ${ }^{156}$.

W 1911 r. przybył do Oświęcimia generał zgromadzenia salezjańskiego, ks. Paweł Albera, z okazji dziesięciolecia poświęcenia zakładu. Odwiedził także schronisko Lubomirskich. Młodzież powoli przyzwyczajała się do nowego porządku wychowawczego. Ważną rolę odgrywało w tym czasie wprowadzenie dużej ilości różnorodnych rozrywek, propagowanie ciekawych dyscyplin sportowych, przygotowywanie przedstawień teatralnych i nauka gry na instrumentach muzycznych. Kilkuletni okres działalności przed pierwszą wojną światową upłynął spokojnie, ale i bardzo pracowicie.

Po wybuchu pierwszej wojny światowej zakład Lubomirskich zmuszony został ograniczyć swoją działalność wychowawczą. Zaborcze władze austriackie zorganizowały tam szpital wojskowy dla jeńców wojennych. Nadal funkcjonowała dyrekcja zakładu $z$ dyrektorem, mieszkającym na miejscu i kilku salezjanami. Dzięki dobrym stosunkom, jakie panowały między komendą szpitala, a dyrektorem oraz autorytetowi, jaki zdobył sobie ksiądz dyrektor wśród chorych pacjentów, zdołano w dużym stopniu uchronić zakład i jego inwentarz przed zniszczeniem. Dyrektor, ks. W. Balawajder głosił jeńcom, głównie Włochom, konferencje i pogadanki oraz udzielał im pomocy duszpasterskiej. Przygotowywano także dla nich krótkie przedstawienia teatralne. W ten sposób udało się uniknąć wielu szkód, a dyrektor zakładu $z$ pobytu jeńców był stosunkowo zadowolony ${ }^{157}$.

154 Tamże, (15 X - 31 XII 1911).

155 Tamże, (7 I 1912).

156 ArITSK, A 563 Kraków-Rakowicka 27. Schronisko im. ks. Lubomirskiego. Wizytacje inspektorialne 1934-1938 1945-1947, Wizytacja inspektora od 24 do 28 XI 1938 r.

157 ArITSK, A 554 Sprawozdanie z czynności fundacji ks. A. Lubomirskiego za lata $1893-$ 1949, Sprawozdanie dyrekcji za rok 1916, 1918. 
W 1914 r. zakład liczył 143 wychowanków. Starsi zaciągnęli się do legionów, a młodsi, w liczbie 27 (sieroty) zostali umieszczeni w zakładzie salezjańskim w Daszawie koło Stryja. Od 1 stycznia 1916 r. przeniesiono ich do zakładu w Radnej (Słowenia). Pozostali tam, pod opieką salezjanów krakowskich odbywali naukę w szkole elementarnej. Pracowali w ogrodzie oraz uczyli się śpiewu i muzyki. Koszty ich utrzymania pokrywane były przez dyrekcję schroniska. Utrzymanie dzienne 1 wychowanka w Radnej wynosiło 1,20 a personelu 2,50 koron austriackich. Przy końcu roku szkolnego 1915/1916 należało pomyśleć o skierowaniu wychowanków do nauki zawodu. Ponieważ zakład w Radnej nie prowadził szkół rzemieślniczych, więc za zgodą prezesa kuratorii wychowanków $\mathrm{z}$ ukończonym 13 rokiem życia (starszych) przeniesiono w sierpniu 1916, wraz z personelem, do zakładu oświęcimskiego. W Oświęcimiu 4 chłopców zostało przyjętych na rok szkolny 1916/1917 do gimnazjum, a koszty ich utrzymania pokrywał zakład oświęcimski. Pozostałych $6, z$ odpłatnością, uczyło się w szkole rzemiosk: krawiectwa 2, szewstwa 2 i stolarstwa 2. Do szkoły elementarnej do klasy IV skierowano 9 uczniów. Najmłodszych uczniów szkoły elementarnej przeniesiono ponownie $z$ Radnej do Daszawy ${ }^{158}$.

Personel zakładu krakowskiego w roku szkolnym 1916/1917 składał się z: dyrektora, dwóch salezjanów - kapłanów, dwóch braci zakonnych, ogrodnika, portiera i dwóch pracowników świeckich. Oprócz zajęć domowych tak salezjanie jak i świeccy pracowali w ogrodzie, który przynosił wtedy nadzwyczajny dochód. W 1916 r. wyniósł on 26407 koron. Wprawdzie i wydatki wzrosły do kwoty 11707 koron. Niemniej jednak środki finansowe z ogrodu, należności za czynsz i pozostałości z remanentu za 1915 r. wystarczyły w zupełności na pokrycie wszelkich wydatków zakładu i utrzymanie w terenie wychowanków.

W kolejnym roku szkolnym zakłady w Daszawie i Oświęcimiu gotowe były przyjąć od 1 września 1917 r. po 20 wychowanków schroniska za ryczałtowym wynagrodzeniem 900 koron za jednego wychowanka na jego utrzymanie i kształcenie. Warunkiem przyjęcia do Oświęcimia było ukończenie szkoły elementarnej. Oferowano dla nich 4 wydziały szkoły rzemiosł: krawiectwo, stolarstwo, ślusarstwo i szewstwo. Zakład daszawski otwarł się dla młodszych uczniów schroniska ${ }^{159}$.

Z końcem roku szkolnego 1917/1918 opuściło zakład 13 wychowanków. Na kolejny rok szkolny 1918/1919 przyjęła dyrekcja 14 nowych. Liczba wszystkich wychowanków wynosiła wówczas 68. Umieszczeni byli w Oświęcimiu (34), w Daszawie (30) i w Miłocinie (4). Z wychowanków oświęcimskich rzemiosła uczyło się: 3 ślusarzy, 6 stolarzy, 13 krawców, 9 szewców. Do gimnazjum uczęszczało 9. Z tych na końcu roku szkolnego opuściło zakład: 4 krawców, 1 ślusarz, 1 szewc, 1 uczeń gimnazjum i 1 zmarł. W Daszawie 10 uczniów ukończyło klasę

158 Tamże, Sprawozdanie dyrekcji za rok 1916.

159 Tamże, Sprawozdanie dyrekcji za rok 1916. 
IV szkoły elementarnej. Z 4 wychowanków umieszczonych w krajowej szkole rolniczej w Miłocinie, w 1919 r. 3 uczniów ukończyło trzyletni kurs rolnictwa. Na kolejny rok szkolny 1919/1920 przyjęto ośmiu nowych wychowanków: 2 do Oświęcimia, 6 do Przemyśla (z braku miejsca w Oświęcimiu). W sumie w tym roku szkolnym zakład krakowski liczył 50 wychowanków ${ }^{160}$.

Zachowanie wychowanków i ich postępy w nauce były pozytywne. Dyrekcje otaczały ich odpowiednią opieką, informując osobiście lub listownie o ich potrzebach i postępach centralę w Krakowie. Ze względów praktycznych dyrektor schroniska, z początkiem października 1918 r., przeniósł się na stałe do zakładu w Oświęcimiu. Pozostawił przy ul. Rakowickiej w Krakowie stałego zastępcę - salezjanina ${ }^{161}$.

W 1918 r. podniosły się koszty utrzymania do 1280 kor. rocznie $(3,5$ koron dziennie) za jednego wychowanka. Powyższa kwota nie pokrywała rzeczywistych wydatków ponoszonych przez zakłady. Zestawienia finansowe wskazują, że samo utrzymanie wynosiło 4,95 kor. dziennie na jednego chłopca. Zarządy poszczególnych zakładów kilkakrotnie zwracały na to uwagę dyrekcji schroniska. Ze względu na wcześniejsze ustne zapewnienia i charakter dobroczynny ich działalności zgodziły się do końca 1918 r. pozostać przy dotychczasowych zniżonych kosztach utrzymania. Zastrzegły jednak stanowczo na 1919 r. podniesienie opłat stosownie do każdorazowych kosztów utrzymania. Ze względu na wzrost cen artykułów żywnościowych i przedmiotów codziennego użytku wyniosły one w tym roku 6,7 kor. dziennie na chłopca ${ }^{162}$.

Rekwizycja wojenna dotknęła schronisko tylko częściowo. Prócz zarekwirowanych w 1915 r. miedzianych naczyń kuchennych w tym samym roku zostały zajęte ślepe piszczałki organów w kaplicy zakładowej. Przeznaczona do rekwizycji miedziana blacha $z$ kopuły budynku ocalała wskutek rozmyślnej zwłoki władz miejscowych.

Prawdziwie ciężki okres dla schroniska rozpoczął się w 1918 r. Wydawałoby się, że po skończonej wojnie powinni zamieszkać w nim wychowankowie, dla których było przeznaczone. Miejsce jeńców zajęło dowództwo legionów oraz umieszczono tam rannych legionistów. Z końcem listopada 1918 r. budynek zakładu przeznaczono dla wenerycznie chorych. Częste zmiany i towarzysząca im dezorganizacja powodowały wielkie szkody, tak w zabudowaniach jak i w ruchomościach. Zniszczono i rozkradziono przyrządy gimnastyczne, wyposażenie sceny i większą część garderoby teatralnej. Ławki szkolne, złożone w piwnicy, częściowo spalono. Sam gmach został zanieczyszczony do najwyższego stopnia. Rekapitulując można powiedzieć, że więcej ucierpiał zakład

\footnotetext{
${ }^{160}$ Tamże, Sprawozdanie dyrekcji za rok 1919.

161 Tamże, Sprawozdanie dyrekcji za rok 1918.

${ }^{162}$ Tamże, Sprawozdanie dyrekcji za rok 1918, 1919.
} 
w krótkim czasie po wyzwoleniu niż w trzech poprzednich latach wojny. Prośby i liczne protesty dyrekcji zarówno w komendzie szpitala jak i w dowództwie generalnym nie przyniosły żadnego skutku. Zapewnienia dowództwa generalnego, że usunie chorych do 1 stycznia 1919 r. okazały się gołosłowne ${ }^{163}$.

Wówczas dyrektor skierował pisma do: Powiatowej Komisji Lokalowej, Prezydium miasta Krakowa (styczeń 1919 r.), Ministra Spraw Wewnętrznych i Wojskowych, Naczelnika Państwa (kwiecień 1919 r.), Ministra Zdrowia Publicznego (czerwiec 1919 r.). Ponadto dyrektor ks. Wojciech Balawajder wraz $\mathrm{z}$ dyrektorem zakładu oświęcimskiego i w porozumieniu z prezesem kuratorii P. Biesiadeckim w połowie maja 1919 r. wyjednali w rządzie zamknięcie szpitala ${ }^{164}$.

Dyrekcja czyniła te zabiegi tym usilniej, gdyż wychowankowie, umieszczeni w Daszawie, znaleźli się od końca listopada 1919 r. w ciężkim i niebezpiecznym położeniu na skutek okupacji tamtejszej placówki przez Ukraińców. Dom został odcięty od reszty polskich placówek salezjańskich. Ogromna drożyzna artykułów pierwszej potrzeby sprawiła, że zakład daszawski przeżywał bardzo trudne czasy. Bezpieczeństwo wychowanków zdane było jedynie na Opatrzność Bożą. Najkrytyczniejsze dni przeżywali oni w Daszawie w pierwszej połowie czerwca 1919 r., kiedy ukraińskie wojsko, cofające się pod naporem oddziałów polskich, obrabowało doszczętnie zakład. Szkody szacowano wówczas na 160 tys. koron. Koadiutor Paweł Przybylak, usiłujący bronić majątku, został zamordowany, a dyrektor - ks. Antoni Kotarski ranny. Chłopcy wprawdzie nie ucierpieli fizycznie, ich utrzymanie jednak było ogromnie trudne. W tej sytuacji ks. Kotarski poinformował dyrekcję, że na rok szkolny 1919/19120 nie może przyjąć nowych wychowanków oraz że zatrzyma tylko tych, którzy dotychczas umieszczeni nie ukończyli jeszcze szkoły ludowej ${ }^{165}$.

Sądzono jednak, mimo biedy, że będzie można kontynuować naukę w roku szkolnym 1919/1920. W jesieni sytuacja pogorszyła się do tego stopnia, że zakład nie zdołał zaopatrzyć się w wystarczającą ilość artykułów żywnościowych na zimę oraz nie posiadał środków na pokrycie bieżących kosztów jego utrzymania. Wskutek tego, większość wychowanków tak miejscowych, jak i krakowskich, w połowie grudnia, rozesłano. Pod opieką dozorcy 13 chłopców przyjechało do Krakowa, skąd udali się do swoich rodzin lub krewnych ${ }^{166}$.

W nieco lepszym położeniu znalazł się zakład w Oświęcimiu. Ale i tam sytuacja zmusiła przełożonych do rozeslania wychowanków na sześć tygodni

1533 Tamże, Sprawozdanie dyrekcji za rok 1918.

164 Tamże, Sprawozdanie dyrekcji za rok 1919.

165 Tamże, Sprawozdanie dyrekcji za rok 1920; 25-lecie, s. 34; Ślós a r czyk, dz. cyt., t. 2, s. 213-214.

106 AIITSK, A 554 Sprawozdania z czynności schroniska fundacji ks. A. Lubomirskiego za lata 1893-1949, Sprawozdanie dyrekcji za rok 1919, 1920; Kronika. Daszawa, PS, 4 (1920) nr 1, s. 13. 
w połowie grudnia 1919 r. Wyjechać musieli również wychowankowie krakowscy. Dopiero po otrzymaniu pomocy aprowizacyjnej z ministerstwa zakład uruchomiono $\mathrm{z}$ początkiem lutego $1920 \mathrm{r}^{167}$.

Trwające trudności aprowizacyjne spowodowały, że zakład w Daszawie do końca roku szkolnego 1919/1920 nie przyjął z powrotem chłopców. Przełożeni zapewniali im miejsce na kolejny rok szkolny 1920/1921. Jednakże na odbytej dnia 27 lipca 1920 r. konferencji przełożonych domu z ks. inspektorem postanowiono opuścić Daszawę, obawiając się nadciągających wojsk rosyjskich. Dzień przed wkroczeniem bolszewików, 19 sierpnia, tak przełożeni, jak i wychowankowie ratowali się ucieczką. Wkrótce znaleźli oni kilkutygodniowe schronienie w zakładzie salezjańskim w Kleczy Dolnej koło Wadowic. $\mathrm{Na}$ miejscu pozostał jedynie proboszcz ks. Józef Bujar i lilku chłopców ${ }^{168}$.

Tab. nr 10: Wychowankowie schroniska w $1920 \mathrm{r}$.

\begin{tabular}{|c|c|c|c|c|c|c|c|}
\hline zakład & ludowa & szewska & krawiecka & stolarska & ślusarska & gimnazjum & ogółem \\
\hline Oświęcim & - & 8 & 6 & 6 & 5 & 3 & 28 \\
\hline Przemyśl & 2 & - & 2 & - & - & - & 4 \\
\hline Daszawa & 5 & - & - & - & - & - & 5 \\
\hline Ogółem & 7 & 8 & 8 & 6 & 5 & 3 & 37 \\
\hline
\end{tabular}

Źródło: ArITSK, A 554 Sprawozdania z czynności schroniska fundacji ks. A. Lubomirskiego za lata 1893-1949, Sprawozdanie dyrekcji za rok 1920.

Z wychowanków szkół rzemieślniczych było w klasie: I - 5, II - 8, III - 12, IV - 2. Razem - 27. Z końcem roku szkolnego 1919/1920 opuściło zaklad w Daszawie 2 uczniów, w Przemyślu 1, w Oświęcimiu 7.

$\mathrm{Z}$ powodu ciągle wzrastających cen i wynikających $\mathrm{z}$ tego wysokich kosztów utrzymania dyrekcja schroniska ograniczyła się do przyjęcia na nowy rok szkolny 1920/1921 tylko 4 uczniów: do Daszawy 1 i do Przemyśla 3.

Tab. nr 11: Liczba wychowanków schroniska w roku szkolnym 1920/1921

\begin{tabular}{|c|c|c|c|c|c|c|c|c|}
\hline zakład & ludowa & szewska & $\begin{array}{c}\text { krawiec- } \\
\text { ka }\end{array}$ & $\begin{array}{c}\text { stolar- } \\
\text { ska }\end{array}$ & $\begin{array}{c}\text { ślusar- } \\
\text { ska }\end{array}$ & $\begin{array}{c}\text { organi- } \\
\text { stowska }\end{array}$ & $\begin{array}{c}\text { gimnaz- } \\
\text { jum }\end{array}$ & ogółem \\
\hline Oświęcim & - & 7 & 4 & 4 & 5 & - & 2 & 22 \\
\hline Przemyśl & 2 & 1 & 4 & - & - & 2 & - & 9 \\
\hline Daszawa & 3 & - & - & - & - & - & - & 3 \\
\hline Ogółem & 5 & 8 & 8 & 4 & 5 & 2 & 2 & 34 \\
\hline
\end{tabular}

Źródło: ArITSK, A 554 Sprawozdania z czynności schroniska ks. A. Lubomirskiego za lata 18931949, Sprawozdanie dyrekcji za rok 1920, 1921.

${ }^{167}$ ArITSK, A 554 Sprawozdania z czynności schroniska fundacji ks. A. Lubomirskiego za lata 1893-1949, Sprawozdanie dyrekcji za rok 1919, 1920.

168 25-lecie, s. 35; Ś w i d a, Towarzystwo Salezjańskie, s. 103. 
Należność za utrzymanie wychowanka w tym roku wynosiła przeciętnie 4200 koron. Jak zapewniały poszczególne dyrekcje, suma ta nie pokrywała w pełni ponoszonych rzeczywistych wydatków.Ciągłe zabiegi prowincjała u kompetentnych władz nie przynosiły i nie rokowały pozytywnych rezultatów. W tej sytuacji ks. Piotr Tirone wysłał petycję do kuratorii w dniu 10 kwietnia 1920 r., w której domagał się zwolnienia salezjanów od wszelkich obowiązków w zarządzie schroniska ${ }^{169}$. Chociaż umowa obowiązywała do 30 czerwca $1926 \mathrm{r}$., zgromadzenie pragnąc prawdziwego dobra i rozwoju schroniska, gotowe było pozostawić kuratorii zupełną swobodę dysponowania zakładem i zdecydowane było ustąpić.

Niezadowolenie społeczeństwa krakowskiego, interwencja członka rodziny fundatora, dra Andrzeja Lubomirskiego z Przeworska ${ }^{170}$ i opór posłów sejmowych, zmusiły kuratorię, odpowiedzialną za dotychczasowy stan fundacji, do zwrócenia salezjanom administracji zakładu w 1925 roku $^{171}$.

Już w grudniu 1924 r. otrzymali salezjanie zapewnienie $w$ starostwie o planowanym, urzędowym oddaniu im administracji zakładu na dzień 17 stycznia 1925 r. W dniach 20-23 grudnia 1924 r. policja, zajmująca parter budynku, wyprowadziła się. W uwolnionej części prowadzono prace remontowe. Naprawy i budowy nowych pieców podjęła się dyrekcja robót publicznych w porozumieniu $z$ kuratorium szkolnym. Zainstalowano wówczas oświetlenie elektryczne. Z zakładu w Kleczy Dolnej i parafii salezjańskiej pw. św. Stanisława Kostki w Krakowie przywożono na ul. Rakowicką 27 wypożyczony wcześniej sprzęt zakładowy. Oddanie zakładu nie nastąpiło w pierwotnie wyznaczonym terminie. Ze strony władz wojewodztwa lwowskiego nie przybyła komisja. Kolejny termin wyznaczono na dzień 2 lutego tego roku ${ }^{172}$.

Na wieść o prowadzonych pracach remontowych w zakładzie zgłaszali się przyszli wychowankowie. Najbardziej zainteresowany i zaangażowany w sprawie ponownego przejęcia zakładu, ks. Adam Cieślar, składając wizytę staroście z okazji świąt wielkanocnych dnia 10 kwietnia tego roku, otrzymał wyjaśnienie, że do sierpnia 1925 r. opróżniona część zakładu będzie służyła jako dom wycieczkowy. Od dnia 14 czerwca ks. Cieślar, mieszkający przy ul. Tynieckiej, przeniósł się na stałe do zakładu Lubomirskich. Już wcześniej, dochodząc tam prowadził oratorium salezjańskie, które liczyło przeszło 60 chłopców. Nazajutrz, po mszy św., odprawionej po raz pierwszy od wielu lat w kaplicy zakładowej, chłopcy przystąpili do jej gruntownego uporządkowania. Od miej-

${ }^{169}$ ArITSK, T. Lubomirscy. Sprawa przejęcia zakładu przed I i po I wojnie światowej, Ks. Tirone do kuratorii 10 IV $1920 \mathrm{r}$.

${ }^{170}$ Tamże, Dr Andrzej Lubomirski do dyrektora schroniska 16 VII $1921 \mathrm{r}$.

171 Tamże, Umowa Zgromadzenia Salezjańskiego z kuratorią z roku 1927.

172 ArITSK, B 1303 Kronika w schronisku Lubomirskich 1924-1926 (8-26 XII 1924, 3, 5, 17 I 1925). 
scowego biskupa ks. Cieślar otrzymał zezwolenie na odprawianie mszy św. w niedziele i święta dla przyjeżdżających grup wycieczkowych ${ }^{173}$.

Dnia 18 czerwca 1925 r. ks. Cieślar otrzymal w starostwie akt fundacji im. księcia Aleksandra Lubomirskiego. Dwa miesiące później, dnia 20 sierpnia przybył na ul. Rakowicką 27 ks. Wojciech Pływaczyk w charakterze radcy zakładu; w trzy dni później kl. Ludwik Griman otrzymał nominację na asystenta. Dnia 27 sierpnia 1925 r. władze miejskie i kuratoria zlikwidowały dom wycieczkowy. Rozpoczęto przyjęcia nowych wychowanków. Przyjęto 20 uczniów ze szkoły przemysłowej. Dzięki pomocy władz miasta, władz szkolnych, duchowieństwa, zakonów, osób prywatnych, jak i współbraci zaopatrzono schronisko w opał, odzież i artykuły żywnościowe dla nielicznej na początek grupy chłopców $^{174}$.

Oficjalne przejęcie zakładu przez salezjanów połączono z przyjazdem generała zgromadzenia ks. Filipa Rinaldiego do Polski i jego wizytą dnia 17 października 1925 w zakładzie Lubomirskich. Program uroczystego przekazania go wypełniły występy instrumentalno-wokalne i deklamacje młodzieży, po których wygłoszono szereg przemówień. Ksiądz A. Cieślar, mianowany dyrektorem zakładu (1925-1927) ${ }^{175}$, witając gości, nakreślił cel reaktywowanej instytucji i przedstawił warunki, w jakich miała kontynuować swoj działalność, po przerwie spowodowanej wojną. W przemówieniach księdza generała, przybyłego $z$ Turynu na tę uroczystość, wiceprezydenta miasta Karola Rolle, radcy E. Czuja z Dębnik (dzielnica Krakowa) i innych przebijała radość ze wskrzeszenia zakładu wychowawczego, spełniającego w Krakowie ważną rolę. Każdy z mówców, w swoim imieniu, zapewniał o gotowości życzliwego i praktycznego poparcia. Personel zakładu w tym czasie stanowili ostatecznie: ks. Adam Cieślar - dyrektor, ks. Wojciech Pływaczyk - prefekt, kl. Ludwik Griman asystent i koad. Jan Jaworski ${ }^{176}$.

Tak rozpoczęta działalność wielkiego zakładu, mimo trudności finansowych, nabierała powoli rozmachu. Odtąd schronisko miało charakter bursy ${ }^{177}$ przeznaczonej dla terminatorów. Cel jej był potrójny: zabezpiecze-

173 Tamże $(10,14-16,18$ IV 1925).

174 Tamże $(20,23,24$ VIII 1925).

175 ASC, S. 389 Klecza Dolna, Ks. W. Balawajder do ks. Karola Gusmana, Klecza Dolna dnia 15 XII $1921 \mathrm{r}$.

${ }^{176}$ Wkrótce $26 \mathrm{X}$ odbyło się pierwsze, w nowych warunkach, posiedzenie kuratorii schroniska, na którym wysluchano sprawozdania dyrekcji z ostatnich kilku lat. ArITSK, B 1303 Kronika w schronisku Lubomirskich 1924-1926 (17, 18, 22 X 1925); Kronika: Kraków, PS, 9 (1925) nr 11, s. 123; Przeglqd dotychczasowej działalności w bursie, „Echo Bursy”, 1 (1926) nr 1, s. 4-5; „Glos Narodu", 1925 nr 248, s. 1.

${ }^{177}$ Bursa (łac. sakiewka: także określenie opłaty mieszkaniowej lub domu zamieszkiwanego przez studentów), zakład związany z instytucją nauczania (uniwersytet, szkoła), służący zbiorowemu zakwaterowaniu i utrzymaniu młodzieży oraz oddziaływaniu wychowawczemu. Bursy wy- 
nie terminatorów przed ujemnymi wpływami środowiska ulicznego, ułatwienie chłopcom biedniejszym zdobycia zawodu ogrodnika poprzez kursy i wreszcie wychowanie chrześcijańskie w oparciu o wskazówki wychowawcze ks. Bosko.

Zmieniły się warunki przyjęcia do zakładu. Przyjmowano chłopców po ukoczeniu 7 klasowej szkoły podstawowej lub 14 roku życia, ze względu na praktykę zawodu. Opłata za pobyt wynosiła $50 \mathrm{zł} \mathrm{miesięcznie,} 5$ zł za pranie i 12 zł jednorazowo wpisowego. Nie znaczy to wcale, że w zakładzie nie było wychowanków, którzy przebywali w nim bez opłaty. Na bezpłatne utrzymanie w zakładzie musiał sobie wychowanek zasłużyć, przede wszystkim nienagannym zachowaniem i sumiennym wykonywaniem codziennych obowiązków ${ }^{178}$. Na początku roku szkolnego 1925/1926 przyjęto do zakładu 115 chłopców. A już w następnym roku było 145 terminatorów ${ }^{179}$.

Po dwóch latach wytężonej pracy dyrektor ks. Cieślar został kierownikiem wydawnictwa salezjańskiego w Warszawie, a jego dotychczasową funkcję objąt ks. Józef Liszka (1927-1930) ${ }^{180}$.

Chłopcy, przebywający w schronisku, w dzień uczęszczali na kursy przemysłowe, kupieckie, do praktyki w handlu lub uczyli się rzemiosła u prywatnych mistrzów; każdy, według swego wyboru i zdolności. Niektórzy ze starszych kończyli jeszcze szkołę podstawową. Od $1926 \mathrm{r}$. kilku $\mathrm{z}$ nich pomagało na stałe $w$ ogrodzie. W miesiącach zimowych uczestniczyli oni w organizowanym w zakładzie kursie ogrodniczym. Na rok szkolny 1928/1929 Kuratorium Okręgu Szkolnego w Krakowie pismem z dnia 24 października $1928 \mathrm{r}$. wyraziło zgodę na prowadzenie w schronisku prywatnej Szkoły Rzemieślniczo-Przemysłowej i zatwierdziło jej statut. Szkoła byla trzyletnia i posiadała wydział ogrodniczy i szewski. W sierpniu 1931 r., za dyrektorstwa ks. Antoniego Kazimierczaka (1930-1932), dział ogrodniczy usamodzielnił się. Od 1 września 1931 r. otwarto szkołę ogrodniczą pod nazwą: Publiczna Szkoła Dokształcająca Zawodowa dla Ogrodników w Krakowie ${ }^{181}$. Nominalnym kierownikiem szkoły został dr Alojzy Sternbach, faktycznie kierował nią

wodzą się z XII-wiecznej działalności uniwersyteckiej benedyktynów, kiedy ich uniwersytety stanęly przed koniecznością rozwiązania problemu mieszkaniowego modzieży, zwłaszcza ubogiej. Por. S. Ku n ow s k i, Bursa, w: Encyklopedia katolicka, t. 2, Lublin 1976, k. 1226-1227.

${ }^{178}$ ArITSK, T. Lubomirscy. Sprawa przejęcia zakładu przed I i po I wojnie światowej, Warunki przyjęcia do zakładu (reklamówka).

${ }^{179}$ Schronisko Lubomirskich odżyto, „Echo Bursy”, 1 (1926) nr 1, s. 1-2.

${ }^{180}$ ASC, S. 389 Klecza Dolna, Ks. Balawajder do ks. Gusmana, Klecza Dolna 15 XII 1921 r.

${ }^{181}$ ArITSK, A 634 Schronisko im. księcia A. Lubomirskiego. Szkoła szewska 1926-1939, Kuratorium do dyrekcji szkoły 28 I 1929 r., Statut Salezjańskiej Szkoły Rzemieślniczo-Przemysłowej, par. 7; K. S z c z e r b a, Salezjańskie szkoty zawodowe w Polsce 1901-1939, Lublin 1973, s. 32, mps. 
ks. A. Sękowski, prefekt ${ }^{182}$ zakładu i kierownik organizowanych kursów ogrodniczych.

Po dwuletnim urzędowaniu ks. Kazimierczaka, dyrektorstwo przejął ks. Sylwester Król (1932/1933-1935/1936). Po nim znowu objął tę funkcję ks. Alojzy Sękowski, który pozostawał na tym stanowisku do 3 października $1950 \mathrm{roku}^{183}$.

Tab. nr 12: Zarząd Schroniska im. Aleksandra Lubomirskiego w latach 1925-1939

\begin{tabular}{|c|c|c|c|c|}
\hline r. szk. & dyrektor & prefekt & radca & katecheta \\
\hline $1925 / 1926$ & A. Cieślar & W. Pływaczyk & - & - \\
\hline $1926 / 1927$ & A. Cieślar & W. Klimczyk & - & - \\
\hline $1927 / 1928$ & J. Liszka & W. Klimczyk & - & - \\
\hline $1928 / 1929$ & J. Liszka & J. Rachwał & - & T. Budnikowski \\
\hline $1929 / 1930$ & J. Liszka & A. Sękowski & T. Głąb & T. Głąb \\
\hline $1930 / 1931$ & A. Kazimierczak & A. Sękowski & J. Domino & J. Domino \\
\hline $1931 / 1932$ & A. Kazimierczak & A. Sękowski & - & - \\
\hline $1932 / 1933$ & S. Król & A. Sękowski & - & - \\
\hline $1933 / 1934$ & S. Król & A. Sękowski & A. Czop & A. Czop \\
\hline $1934 / 1935$ & S. Król & A. Sękowski & E. Kachnicz & E. Kachnicz \\
\hline $1935 / 1936$ & S. Król & A. Sękowski & S. Domino & S. Domino \\
\hline $1936 / 1937$ & A. Sękowski & W. Konieczny & W. Konieczny & S. Domino \\
\hline $1937 / 1938$ & A. Sękowski & W. Konieczny & J. Szczupał & S. Domino \\
\hline $1938 / 1939$ & A. Sękowski & A. Sękowski & K. Kiełt & $\begin{array}{c}\text { A. Sękowski } \\
\text { J. Szczupał } \\
\text { A. Swwida }\end{array}$ \\
\hline
\end{tabular}

Źródło: ArITSK, A 627 Schronisko Lubomirskich, Protokoły kapituł domowych 7 II 1927 r. 11 IX 1950 r,; Elenco della Societa di San Francesco di Sales (dalej cyt. Elenco), Torino 1926-1940.

${ }^{182}$ „Prefekt zastępuje dyrektora, a głównym jego obowiązkiem jest zarządzanie rzeczami materialnymi, mieć staranie o domowników i bacznym okiem czuwać nad karnością wychowanków według regulaminu danego domu i zgody dyrektora", Ustawy i Regulaminy, art. 116. (Ust.).

${ }^{183}$ S l ó s a r czy k, dz. cyt., t. 2, s. 254. 
Tab. nr 13: Stan wychowanków schroniska w latach 1925-1950

\begin{tabular}{|c|c|}
\hline rok & liczba wychowanków \\
\hline $1925 / 1926$ & 120 \\
\hline $1926 / 1927$ & 145 \\
\hline $1927 / 1928$ & 142 \\
\hline $1928 / 1929$ & 139 \\
\hline $1929 / 1930$ & 151 \\
\hline $1930 / 1931$ & 125 \\
\hline $1931 / 1932$ & 100 \\
\hline $1932 / 1933$ & 91 \\
\hline $1933 / 1934$ & 85 \\
\hline $1934 / 1935$ & 85 \\
\hline $1935 / 1936$ & 106 \\
\hline $1936 / 1937$ & 112 \\
\hline $1937 / 1938$ & 90 \\
\hline $1938 / 1939$ & 74 \\
\hline $1939 / 1940$ & 128 \\
\hline $1940(1945)$ & 10 u oo. karmelitów \\
\hline $1946 / 1947$ & 76 \\
\hline $1947 / 1948$ & 94 \\
\hline $1948 / 1949$ & 110 \\
\hline $1949 / 1950$ & 122 \\
\hline $1950 / 1951$ & 101 \\
\hline
\end{tabular}

Źródło: ArITSK, A 539 Schronisko im. ks. A. Lubomirskiego. Spis wychowanków 1912-1939 i 1946-1950, Spis sierot (pótsierot) schroniska w 1925 r., Wykaz małoletnich zamieszkałych w zakładzie w 1926 r., Alfabetyczny spis wychowanków zakładu z 15 X 1928 r., Wykaz wychowanków schroniska z 1 I 1931 r. i 1 I 1932 r., Lista wychowanków na rok szkolny 1935/1936, 1936/1937, Lista wychowanków z 1 I 1938 r., Spis wychowanków na rok szkolny 1946/1947, 1947/1948, Stan wychowanków z 5 IX 1948 r., Spis wychowanków na rok szkolny 1948/1949, 1949/1950.

W latach 1925-1939 obserwujemy tendencję spadkową liczby chłopców w schronisku. Jest ona o tyle uzasadniona, że po pierwszej wojnie światowej kapitał fundacyjny przepadł prawie zupełnie, a byt materialny zakładu uzależniony był w znacznej części od przedsiębiorczości administracji.

W czasie drugiej wojny światowej schronisko było okupowane najdłużej przez wojska niemieckie. Gdy zakład został opróżniony, mimo olbrzymich 
zniszczeń wojennych i dewastacji, salezjanie postanowili wznowić tam pracę wychowawczą. Brakowało kwater okiennych na drugim i w części pierwszego piętra. Spaleniu uległo wiele drzwi i podłóg. Piece kaflowe, przewody kanalizacyjne i wodociągowe były kompletnie zniszczone. Inwentarz sypialni, szkół, biur i pokojów prywatnych został wywieziony lub rozkradziony. Prace remontowe należało przeprowadzać w miarę ówczesnych możliwości finansowych.

Po wyremontowaniu parteru salezjanie uruchomili bursę, do której przeniesiono 8 chłopców, mieszkających dotychczas u ojców karmelitów. Przybyło także 8 wychowanków z ul. Tynieckiej 39 wraz z ks. Antonim Bursiewiczem. Dyrektor zakładu ks. Sękowski zawiadomił Urząd Wojewódzki i Kuratorium Okręgu Szkolnego Krakowskiego o rozszerzeniu działalności wychowawczej w częściowo wyremontowanym już budynku. Na dzień 1 lipca 1946 r. mieszkało 16 wychowanków, 1 sierpnia - 17, 1 września $-20,1$ października - 45, 1 listopada - 49, 1 grudnia - $65^{184}$.

Tab. nr 14: Personel bursy w zakładzie fundacji im. A. Lubomirskiego w latach 19461950

\begin{tabular}{|c|c|c|c|c|}
\hline r. szk. & dyrektor & prefekt & radca & katecheta \\
\hline $1946 / 1947$ & A. Sękowski & A. Bursicwicz & E. Żołyniak & C. Rogowski \\
\hline $1947 / 1948$ & A. Sękowski & A. Sękowski & Z. Wal & E. Zołyniak \\
\hline $1948 / 1949$ & A. Sękowski & A. Sękowski & Z. Wal & J. Hołyński \\
\hline $1949 / 1950$ & A. Sękowski & Z. Wal & J. Thoma & - \\
\hline
\end{tabular}

Źródło: ArITSK, A 627 Schronisko Lubomirskich, Protokoły posiedzeń kapituł domowych od 9 X 1946 r. do 11 IX 1950 r.; Elenco, 1947-1950.

Kiedy bursa już funkcjonowała zainteresowała się nią kuratoria fundacji. W piśmie z dnia 21 sierpnia 1946 r. zwracała się z prośbą do dyrektora o przygotowanie sprawozdania od sierpnia 1939 r. i o wyznaczenie posiedzenia kuratorii z dyrekcją zakładu. Pismem z dnia 6 grudnia 1948 r. kuratoria zerwała umowę $z$ administrującym zakładem zgromadzeniem salezjańskim, polecając równocześnie przekazanie obiektu dnia 5 stycznia 1949 r. wyznaczonej komisji ${ }^{185}$.

Po ukończeniu remontu 23 listopada 1949 r. Wojewódzka Komisja Lokalowa przeprowadziła przegląd obiektu. Na początku grudnia przewodniczący kuratorii oddał 2 piętro zakładu do dyspozycji studentów. Kolejne decyzje

\footnotetext{
${ }^{184}$ ArITSK, B 1504 Schronisko Lubomirskich. Kronika 1927-1950 (1946-1950).
}

${ }^{185}$ Warto przypomnieć, że od początku kuratorem fundacji był każdorazowy starosta powiatowy, a po II wojnie światowej wojewoda krakowski. ArITSK, B 1504 Schronisko Lubomirskich. Kronika 1927-1950 (1946-1950). 
Wojewodzkiej Komisji Lokalowej zmierzały do szybkiej likwidacji katolickiej placówki wychowawczej. Praca na rzecz młodzieży szkolnej, mieszkającej w bursie, zakoczyła się definitywnie w październiku $1950 \mathrm{roku}^{186}$.

\section{Kuratoria fundacji jako organ nadzoru schroniska}

Ustawa z 12 sierpnia 1866 r. oddawała wszystkie formy działalności charytatywno-wychowawczej w Galicji pod nadzór samorządów miejskich i gminnych. W konsekwencji nadzór ten sprowadzał się do rejestracji ich w urzędach miejskich i gminnych. Chodziło głównie o przejęcie kontroli przez państwo nad kościelnymi instytucjami charytatywnymi ${ }^{187}$.

Książę A. Lubomirski, zamieszkały w Paryżu, przeznaczając część swego majątku na cele społeczno-wychowawcze, aktem z 31 sierpnia 1885 r. umieścił go w c.k. Głównej Kasie Krajowej we Lwowie ${ }^{188}$. Instytucjami, które z tego funduszu miały powstać, nie mógł zająć się osobiście. Dlatego konieczne stało się ustanowienie kuratora, czyli opiekuna prawnego, któremu powierzono budowę zakładu i prowadzenie przyszłej fundacji. W myśl powyższej ustawy, głównym zarządcą fundacji A. Lubomirskiego było Namiestnictwo Galicji i Wielkiego Księstwa Krakowskiego we Lwowie. Namiestnictwo z kolei ustanowiło kuratorię, która jako organ nadzorczy czuwała nad wypełnieniem aktu fundacyjnego, a tym samym miała decydujące znaczenie w uchwalaniu budżetu, mianowaniu personelu administracyjno-wychowawczego i nadawaniu kierunku wychowania ${ }^{189}$.

Członków kuratorii mianował Rząd Krajowy a tworzyli ją: przewodniczący, zastępca i 6-10 członków. Minister Spraw Wewnętrznych, na wniosek namiestnika, zatwierdzał na okres sześciu lat przewodniczącego kuratorii, zazwyczaj prezydenta miasta Krakowa, jego zastępcę i członków ${ }^{190}$. Przewodniczący miał prawo wyręczyć się w swej działalności specjalnie mianowanym urzędnikiem. Pierwszym przewodniczącym kuratorii fundacji A. Lubomirskiego został w 1891 r. Kazimierz Laskowski. Na jego barkach spoczęło prowadzenie budowy gmachu zakładu. Następnie, wraz z członkami kurato-

${ }^{186}$ Dnia $3 \times 1950$ r. wpłynęło do dyrektora pismo o przekazaniu studentom wszystkich pomieszczeń zakładu, $6 \mathrm{X}$ nastąpiło ich przejęcie, $10 \mathrm{X}$ salezjanie opuścili gmach, do $20 \mathrm{XII}$ czynna byla kaplica, a 24 IV 1952 r. wyszedł dekret o zniesieniu fundacji. Dnia 30 VIII 1952 r. kaplica została zlikwidowana. ArITSK, A 11 Likwidacja. Schronisko Lubomirskich.

${ }^{187} \mathrm{M}$ a j k a, dz. cyt. s. 120-121.

${ }^{188}$ ArITSK, B 1504 Schronisko Lubomirskich. Kronika 1927-1950 (X 1927).

${ }^{189}$ ArTSK, T. Zakład księcia Aleksandra Lubomirskiego w Krakowie, Akt fundacyjny, art. 8.

${ }^{190}$ ArITSK, T. Schronisko im. ks. A. Lubomirskiego, Statut schroniska, § 47. 
rii, prowadził pertraktacje, za pośrednictwem Konsystorza Książęco-Biskupiego, z różnymi zgromadzeniami zakonnymi, odnośnie do obsadzenia stanowisk administracyjno-wychowawczych schroniska ${ }^{191}$. Równocześnie kuratoria przeprowadziła sondaż na stanowisko dyrektora zakładu ${ }^{192}$.

Kuratorię na zewnątrz reprezentował jej przewodniczący. Wszystkie uchwały i zarządzenia musiały być opatrzone jego podpisem i przynajmniej jednego z członków. Do kuratorii należał ponadto członek rodziny fundatora, książę Andrzej Lubomirski z Przeworska. Posiedzenia odbywały się w gmachu schroniska co trzy miesiące. Praktycznie miały one miejsce w styczniu, kwietniu, lipcu i październiku. Nadzwyczajne posiedzenie zwoływano z polecenia władzy naczelnej, według uznania przewodniczącego, a w razie potrzeby na prośbę dyrekcji zakładu.

Przedmiot obrad przygotowywał tzw. wydział wykonawczy, złożony z przewodniczącego i dwóch członków. W mocy przewodniczącego było zawieszenie wykonania uchwał kuratorii, jeśli uznał to za sprzeczne ze statutem organizacyjnym lub prawem cywilnym. Obowiązany był powiadomić o tym w ciągu trzech dni namiestnictwo, które podejmowało dalsze decyzje. Od zarządzeń kuratorii, osobom zainteresowanym przysługiwało odwołanie w ciagu 14 dni do namiestnictwa, które wydawało ostateczną decyzję ${ }^{193}$. Wszystkie uchwały zapadały absolutną większością głosów. Jeżeli uchwała nie mogła dojść do skutku, ze względu na brak quorum, przewodniczący wyznaczał ponowne posiedzenie w ciągu ośmiu dni, na którym zapadały decyzje wiążące, bez względu na ilość członków. W posiedzeniach kuratorii ze strony zarządu zakładu brali udział: dyrektor, kapelan i przełożona sióstr ( $\mathrm{z}$ głosem doradczym $)^{194}$. Przewodniczący, przynajmniej $z$ jednym członkiem, zobowiązany był kontrolować księgi rachunkowe i kasę, magazyny i inwentarz fundacji. W praktyce jednak czynił to delegowany członek kilka a nawet kilkanaście razy do roku, a następnie zdawał sprawozdanie pisemne przewodniczącemu. $\mathrm{Na}$ miejscu pozostawiał $\mathrm{w}$ księdze wizytacyjnej uwagi pozytywne jak i spostrzeżenia negatywne. Zaznaczał wyraźnie polecenia do wykonania na przyszłość. Na taką inspekcję przybywał zawsze nie zapowiedziany i o bardzo różnych porach: w czasie śniadania, na rekreacji, podczas zajęć szkolnych, a nawet wieczorem ${ }^{195}$.

191 AKMKr, 202 Salezjanie, Kuria Biskupia do kuratorii 6 VII 1909 r.

192 AKMKr, 202 Salezjanic, Dekret zatwierdzający ks. A. Langa na dyrektora schroniska, Lwów 3 VIIl $1893 \mathrm{r}$.

193 ArITSK, T. Schronisko im. ks. A. Lubomirskiego, Statut schroniska, § 48.

194 Tamże, $\$ 49$.

195 ArITSK, A 550 Schronisko fundacji ks. A. Lubomirskiego w Krakowie. Księga wizytacyjna kuratorii schroniska od 12 XII 1896 r. do 12 VIII 1914 r. 
Tab. nr 15: Wizytacje kuratorii w schronisku w latach 1896- 1914

\begin{tabular}{|c|c|c|c|}
\hline rok & ilość wizytacji & rok & ilość wizytacji \\
\hline 1896 & 1 & 1906 & 1 \\
\hline 1897 & 11 & 1907 & 2 \\
\hline 1898 & 7 & 1908 & 11 \\
\hline 1899 & 3 & 1909 & 11 \\
\hline 1900 & 1 & 1910 & 15 \\
\hline 1901 & 1 & 1911 & 12 \\
\hline 1902 & 2 & 1912 & 10 \\
\hline 1903 & 0 & 1913 & 8 \\
\hline 1904 & 1 & 1914 & 8 \\
\hline 1905 & 2 & & \\
\hline
\end{tabular}

Źródlo: ArITSK, A 550 Schronisko fundacji ks. A. Lubomirskiego w Krakowie. Księga wizytacyjna kuratorii schroniska od 12 XII $1896 \mathrm{r}$. do 12 VIII $1914 \mathrm{r}$.

Kuria biskupia, sprawująca duchową opiekę nad fundacją, przedstawiała kuratorii kandydata na kapelana. Z chwilą mianowania go przez kuratorię i po zatwierdzeniu przez namiestnictwo, rozpoczynał on pełnienie obowiązków w schronisku ${ }^{196}$. Kuratoria mianowała także nauczycieli szkolnych, a zatwierdzała ich Rada Szkolna Krajowa. Kuratoria zaś zatwierdzała regulamin domowy, przedstawiony jej przez dyrekcję. Wskazywała również rzemieślników w mieście, $\mathrm{u}$ których terminatorzy schroniska mieli odbywać praktykę zawodową. $Z$ końcem roku kalendarzowego, a najdalej do końca stycznia, dyrekcja wysyłała do kuratorii pisemne sprawozdanie o stanie zakładu, a do końca lutego przedstawiała preliminarz budżetowy na rok bieżący, $\mathrm{z}$ propozycją zmian w urządzeniu zakładu. Skrupulatne rozliczanie dyrekcji z wydatków krępowało niejednokrotnie działalność wychowawczą ${ }^{197}$. Dyrektor schroniska, na wszystkie przedsięwzięcia, jakie zamierzał podjąć, począwszy od przyjęcia wychowanka, poprzez jego pobyt aż do ukończenia szkoły, odbyciu praktyki, a nawet decyzję o dyscyplinarnym usunięciu go, obowiązany był uzyskać najpierw zgodę kuratorii ${ }^{198}$. Wyjątkowo dla dobra wychowanków i zakładu mógł on na własną rękę usunąć karnie wychowanka. Natychmiast po tym

${ }^{196}$ Np. Dekret nominacji na kapelana schroniska im. ks. A. Lubomirskiego, ArITSK, T. Schronisko Lubomirskich, Kuratorium do ks. Hlonda 24 X 1905 r.

${ }^{197}$ Kuratoria nie chciała zgodzić się na przebudowę zakładu, by salezjanie mogli podjąć, równocześnie z siostrami miłosierdzia, pracę, gdyż wiązało się to z uszczupleniem majątku fundacji.

${ }^{198}$ ArITSK, T. Schronisko im. ks. A. Lubomirskiego, Statut schroniska, $§ 50$. 
fakcie zobowizany by zawiadomić kuratorię, podając powody wydalenia. We wszelkich innych sprawach był od niej zależny. W wielu więc wypadkach kuratoria krępowała działalność dyrekcji.

Od 1903 r. kuratoria prowadziła długoletnie pertraktacje z salezjanami odnośnie objęcia przez nich administracji zakładu. Trwały one osiem lat i zostały pomyślnie zakończone dopiero w 1911 r. Kuratoria oddała wówczas zarząd i pracę $w$ schronisku salezjanom ${ }^{199}$.

Stanowisko, jakie zajęła kuratoria po zakończeniu pierwszej wojny światowej, wydaje się niezrozumiałe. W 1921 r., po zlikwidowaniu szpitali: austriackiego i polskiego, postanowiła oddać budynki zakładu z przeznaczeniem na urzędy państwowe, m.in. na biura kuratorium szkolnego, na mieszkania prywatne dla urzędników państwowych i osób prywatnych. Do tego czasu funkcjonowała dyrekcja schroniska, a wychowankowie byli utrzymywani na koszt zakładu w placówkach salezjańskich w Daszawie, Radnej, Oświęcimiu, Przemyślu i Kleczy Dolnej ${ }^{200}$. Dopiero w 1925 r. kuratoria fundacji oddała schronisko do użytku młodzieży. Wytłumaczeniem czteroletniej zwłoki (1921-1925) może być tylko fakt, że, po przepadku majątku (żelaznego kapitału) fundacji, umieszczonego w bankach austriackich, na skutek dewaluacji pieniądza, budynek zajęty na szpitale, po ich opróżnieniu kuratoria wydzierżawiła na 3 lata gubernatorowi prowincji, czyli rządowi. Kontrakt dzierżawy za 12 tys. zł rocznie miał rzekomo wzmocnić kapitał fundacji, by ta mogła nadal spełniać swe pierwotne zadanie. Pozostawał tam tylko jeden kapłan administrator zakładu i dwóch koadiutorów, z których jeden zajmował się obszernym ogrodem ${ }^{201}$. Ówczesny dyrektor schroniska, mieszkający w Oświęcimiu, ks. Wojciech Balawajder dwukrotnie, tj. 14 lutego i 3 czerwca 1921 r. przedkładał kuratorii propozycję prowadzenia przez salezjanów schroniska na własny rachunek. Propozycje ponowił jeszcze ustnie na posiedzeniu kuratorii 6 czerwca 1921 roku $^{202}$. Było to już w czasie, kiedy ze schroniska usunięto szpital. Propozycja ta niestety nie została przyjęta.

Ogólnie podsumowując kompetencje kuratorii należy stwierdzić, że podporządkowanie jej dalekiemu namiestnictwu we Lwowie było tylko formalne. Faktycznie kuratoria podejmowała wszelkie decyzje, często nawet wbrew

${ }^{199}$ Bursa dla mtodzieży rekodzielniczej i przemystowej im. Lubomirskiego $w$ Krakowie (1911), PS, 12 (1928) nr 1, s. 32-33.

${ }^{200}$ ArITSK, A 554 Sprawozdania z czynności schroniska fundacji ks. A. Lubomirskiego za lata 1893-1949, Sprawozdanie z działalności schroniska od 1 IV 1930 r. do 31 III 1931 r.

201 ASC, S. 389 Klecza Dolna, Ks. Balawajder do ks. Gusmana, Klecza Dolna 15 XII 1921 r.; ArITSK, T. Lubomirscy. Sprawa przejęcia zakładu przed I i po I wojnie światowej, A. Lubomirski do dyrektora schroniska 16 VII $1921 \mathrm{r}$.

${ }^{202}$ ArITSK, T. Lubomirscy. Sprawa przejęcia zakładu przed I i po I wojnie światowej, Ks. Tirone do kuratorii 4 III $1923 \mathrm{r}$. 
zobowiązaniom podjętym w umowie. Trzeba dodać, że kuratoria, po ponownym otwarciu schroniska $w 1925$ r., nadal działała na tych samych prawach i z tymi samymi kompetencjami, co przedtem. Jednak jej moralny autorytet niepomiernie zmalat.

\section{ROZDZIAE III PODSTAWY MATERIALNE}

Podstawowym problemem dla wszelkich instytucji o charakterze dobroczynno-charytatywnym w XIX w., prowadzonych przez zakony, osoby duchowne czy organizacje kościelne, była kwestia ich utrzymania i zapewnienia im stopniowego rozwoju. Wiązało się to z poważnymi wydatkami finansowymi. W większości, podstawą do utworzenia zakładu wychowawczego, był stały fundusz, majątek pochodzący $z$ fundacji lub darowizny (niejednokrotnie terminów tych używano zamiennie). Kodeks Prawa Kanonicznego ${ }^{203}$ precyzuje ściśle pojęcie i charakter fundacji. Rozumie przez nią majątek oddany osobie moralnej $\mathrm{w}$ Kościele $\mathrm{z}$ obowiązkiem pełnienia oznaczonych czynności, do których należy także opieka nad ubogimi i sierotami. Nie ma tej klauzuli w odniesieniu do darowizny. Salezjanie w pierwszych latach swej pracy wychowawczej i duszpasterskiej na ziemiach polskich uzależnili ją w znacznej mierze od takich źródeł utrzymania ${ }^{204}$.

\section{Kapital fundacyjny}

Schronisko powstało $\mathrm{z}$ fundacji księcia A. Lubomirskiego, który, jak wspomniano, ofiarował sumę 2 mln franków listem fundacyjnym z dnia 31 sierpnia 1885 r. na dwa zakłady opiekuńcze: męski i żeński. Kwota ta została przekazana Wydziałowi Krajowemu we Lwowie, na ręce namiestnika Galicji, H. Zaleskiego, a w końcu wymieniona na walutę austriacką i zdeponowana w bankach. Po rozdziale na dwie instytucje wychowawcze: dla chłopców i dla dziewcząt, na konto schroniska przypadło $1,5 \mathrm{mln}$ koron austriackich ${ }^{205}$. W 1887 r. zakupiono odpowiednią parcelę w Olszy (od 1941 r. dzielnica Krakowa) za cenę $23.660 \mathrm{złr}^{206}$. Rozpoczęte od wiosny 1891 r. prace budowlane zostały ukończone w jesieni $1893 \mathrm{r}$.

Majątek schroniska fundacji księcia Aleksandra Lubomirskiego stanowiła realność gruntowa, na której stanął budynek główny zakładu i budynki gos-

${ }^{203}$ Codex Juris Canonicis, Romae 1941, can 1513, 1544.

${ }^{204}$ Sty rn a, dz. cyt., s. 11, 34.

${ }^{205}$ Kronika. Przeglad dotychczasowej działalności w Bursie, „Echo Bursy”, 1 (1926) nr 1, s. 5-6.

${ }^{206}$ ArITSK, T. Zakład księcia Aleksandra Lubomirskiego w Krakowie, Akt fundacyjny. 
podarcze. W skład majątku zaliczono także wyposażenie zakładu w niezbędne urządzenia, zbiory, pomoce naukowe oraz całe zaplecze gospodarcze.

Po skończonych pracach budowlanych i wyposażeniowych zakład rozpoczął swoją działalność wychowawczo-dydaktyczną, dysponując jeszcze sumą 900 tys. złr. Kwota ta stanowiła ,żelazny kapitał" i była w depozycie namiestnictwa, które ustanowiło kuratorię, czyli organ dla bezpośredniego nadzoru wychowawczoadministracyjnego nad zakładem. Kuratoria powoływała zarząd, który z końcem każdego roku przedstawiał jej do zatwierdzenia preliminarz budżetowy. Dopiero po jego zatwierdzeniu, zarząd zakładu realizował swe przedsięwzięcia w zatwierdzonych ramach finansowych. Dysponował on sumą otrzymywaną z oprocentowanych 900 tys. złr, która wynosiła rocznie około 90 tys. $z \mathrm{rr}^{207}$. Początkowo wystarczała ona w zupełności na pokrycie kosztów, związanych $z$ normalnym funkcjonowaniem schroniska, czyli na wyżywienie i utrzymanie wychowanków, dyrekcji i personelu wychowawczego oraz służby pomocniczej wraz $\mathrm{z}$ ich wynagrodzeniem ${ }^{208}$.

Tab. nr 16: Wynagrodzenie miesięczne pracowników schroniska w latach 1893-1914

\begin{tabular}{|l|c|c|}
\hline \multicolumn{1}{|c|}{ stanowisko } & $\begin{array}{c}1893-1899 \\
\text { w ztr. }\end{array}$ & $\begin{array}{c}1900-1914 \\
\text { w koronach }\end{array}$ \\
\hline dyrektor & 1.350 & 2.100 \\
\hline kapelan & 800 & 1.600 \\
\hline zarządca & 800 & 1.600 \\
\hline nauczyciel & 900 & 1.800 \\
\hline ochmistrz & 480 & 1.200 \\
\hline ogrodnik & 600 & 1.200 \\
\hline kucharz & 600 & 1.200 \\
\hline dozorca & 600 & 1.200 \\
\hline 5 sióstr & 400 & 1.200 \\
\hline
\end{tabular}

Źródlo: ArITSK, A 554 Sprawozdania z czynności schroniska fundacji ks. A. Lubomirskiego za lata 1893-1949, Sprawozdanie dyrekcji za rok 1907 (płace dzienne robocizny rok 19051907), 1913.

$\mathrm{Za}$ administracji salezjańskiej dyrekcja i personel wychowawczo-dydaktyczny nie pobierali należności za pracę. Zatrudniony z zewnątrz personel dydaktyczny i pracownicy fizyczni otrzymywali wynagrodzenie, według stawek

${ }^{207}$ Pły w a c z y k, dz. cyt., s. 221.

208 ArITSK, T. Schronisko fundacji Lubomirskich, Pensje za rok 1899. Przelicznik w tym czasie wynosil: 1 zloty reński $=2$ korony. 
uzgodnionych w umowie. Oprócz tego niektórych z nich wynagrodzano płodami rolnymi.

Tab. nr 17: Wysokość wynagrodzenia miesięcznego pracowników w latach 1931/1932 $-1936 / 1937$ (w złotych)

\begin{tabular}{|c|c|c|c|c|c|}
\hline r. szk. & lekarz & ogrodnik & kapelmistrz & $\begin{array}{c}\text { kuchnia } \\
\text { pralnia } \\
\text { ogród }\end{array}$ & $\begin{array}{c}\text { ilość } \\
\text { zatrudnionych }\end{array}$ \\
\hline $1931 / 1932$ & 1800 & 2400 & 480 & 300 & 11 \\
\hline $1932 / 1933$ & 1200 & 2400 & 480 & 300 & 12 \\
\hline $1933 / 1934$ & 700 & 2400 & - & 300 & 12 \\
\hline $1934 / 1935$ & 720 & 2400 & - & 300 & 12 \\
\hline $1935 / 1936$ & $?$ & 2160 & - & 300 & 12 \\
\hline $1936 / 1937$ & $?$ & 2160 & - & 300 & 11 \\
\hline
\end{tabular}

Źródło: ArITSK, A 554 Sprawozdania z czynności schroniska fundacji ks. A. Lubomirskiego za lata 1893-1949, Sprawozdania zakładu opiekuńczego za lata 1931/1932 - 1936/1937.

W pierwszym dziesięcioleciu, kiedy liczba wychowanków wzrastała od 32 w 1893 r. z każdym rokiem o około 20, aż do liczby określonej statutem, czyli 120 wychowanków w 1899 r., kwoty według sporzdzonego sprawozdania finansowego na zakończenie roku, były niższe od zatwierdzonego preliminarza ${ }^{209}$.

Tab. nr 18: Wydatki roczne schroniska w latach 1899-1913

\begin{tabular}{|c|c|}
\hline rok & koron \\
\hline 1899 & 72.432 .00 \\
\hline 1900 & 62.812 .00 \\
\hline 1902 & 85.594 .00 \\
\hline 1904 & 79.744 .00 \\
\hline 1905 & 78.987 .00 \\
\hline 1913 & 91.584 .00 \\
\hline
\end{tabular}

Źródło: ArITSK, A 554 Sprawozdania z czynności schroniska fundacji ks. A. Lubomirskiego za lata 1893-1949, Sprawozdanie dyrekcji za rok 1902 (porównanie preliminarza $\mathrm{z}$ wydatkami w 1902 r.), 1913.

Widać $\mathrm{z}$ tego, że średnio, miesięcznie wydatki zakładu, oscylowały w granicach 7 tys. koron, $z$ tym, że w miesiącach wakacyjnych kwota ta była odpowiednio niższa.

${ }^{209}$ Tamże, Sprawozdanie finansowe 1899-1913. 
Znaczny dochód, odpowiadający średnio dziesiątej części jego rocznych wydatków, przynosił także ogród, którego powierzchnię uprawną z roku na rok proporcjonalnie zwiększano.

Tab. nr 19: Finanse ogrodu zakładowego w latach 1899-1913 ( w koronach)

\begin{tabular}{|c|c|c|c|}
\hline rok & dochód & wydatki & nadwyżka \\
\hline 1899 & $?$ & $?$ & 2.700 .00 \\
\hline 1900 & 8.091 .35 & 6.888 .91 & 1.202 .41 \\
\hline 1904 & $?$ & $?$ & 8.097 .00 \\
\hline 1912 & 8.411 .33 & 7.336 .02 & 1.075 .31 \\
\hline 1913 & 8.979 .38 & 8.009 .14 & 970.24 \\
\hline
\end{tabular}

Źródło: ArITSK, A 554 Sprawozdania z czynności schroniska fundacji ks. A. Lubomirskiego za lata 1893-1949, Sprawozdanie dyrekcji za rok 1900, Bilans przychodów i wydatków w ogrodzie w roku 1900, 1912, 1913.

Ustalony w pierwszym okresie funkcjonowania schroniska preliminarz budżetowy był w następnych latach na ogól powielany, przez co zarząd dążył do daleko idących oszczędności. Preliminarz nie uwzględniał nadzwyczajnych wydatków, koniecznych - w opinii dyrektora - do modernizacji urządzeń socjalnych schroniska, potrzebę których potwierdziła późniejsza praca i funkcjonowanie zakładu ${ }^{210}$. Zaoszczędzone, kosztem wychowanków, pieniądze dołączano do zasadniczej sumy kapitału po zakończeniu każdego roku administracyjnego. Do tego oprocentowanego kapitału należało dołączać także ewentualne dary lub zapisy władz miejskich, stowarzyszeń czy osób prywatnych ${ }^{211}$.

Stan taki utrzymywał się do 1905 r., kiedy na prośbę Kurii Biskupiej Krakowskiej, kapelanem schroniska został ks. August Hlond, salezjanin. Nieco wcześniej rozpoczęły się pertraktacje zgromadzenia z kuratorią na temat przejęcia kierownictwa i administracji przez salezjanów. Nie chcieli oni przystać na propozycję kuratorii, proponującej im zajęcie się chłopcami starszymi. Szarytki miałyby bowiem dalej pozostać przy „maluchach". Salezjanie godzili się na to, pod warunkiem stworzenia dwóch oddzielnie działających zakładów zamkniętych, posiadających wspólną dyrekcję. Prowadzone pertraktacje przedłużały się, a żadna ze stron nie chciała ustąpić. Począwszy od $1905 \mathrm{r}$. liczba wychowanków ciągle malała: ze 145 w 1905 r. spadła ona do 80 w 1911 r.

Niełatwo ustalić przyczyny tego stanu. Wydaje się, że kuratoria nie była tu bez winy, ponieważ dbała ona jedynie o majątek i zabiegała o jego powięk-

${ }^{210}$ Tak bylo od momentu rozpoczęcia pertrakctacji kuratorii z salezjanami od 1904 r. Salezjanie proponowali przeprowadzić modernizację zakładu, by mogli podjąć pracę ze starszymj chłopcami, a siostry szarytki pracowałyby w dalszym ciągu nad młodszymi.

${ }^{211}$ ArITSK, T. Schronisko im. ks. A. Lubomirskiego, Statut schroniska, \& 2. 
szanie. Tymczasem wysokie koszty utrzymania wychowanków prowadziły automatycznie do zmniejszania ich liczby. Rezygnacja sióstr z dalszej pracy w 1911 r. została przyjęta przez kuratorię z ulgą ${ }^{212}$.

Salezjanie objęli zarząd fundacji we wrześniu $1911 \mathrm{r}$. Zgromadzenie przejęło wszystkie obowiązki i prawa, według aktu fundacyjnego i statutu organizacyjnego. Utrzymane jednak zostało w mocy prawo nadzoru i kontroli kuratorii fundacji, która zabezpieczała byt materialny zakładu. Pod zarządem ks. J. Świerca, zastępcy pierwszego dyrektora salezjańskiego, ks. E. Manassero, zakład utrzymywał się z sum otrzymanych z oprocentowanego kapitału. Ponadto salezjanie zrezygnowali $\mathrm{z}$ pensji, z zastrzeżeniem, że przejmą ogród z cieplarnią we własną administrację. Nie oznaczało to wyjęcia tychże spod kontroli kuratorii, która przyjęła pozytywnie tę propozycję. Sytuacja zakładu poprawiła się, o czym świadczy wzrost liczby wychowanków z $80 \mathrm{w}$ roku szkolnym 1910/1911 do $150 \mathrm{w}$ następnym. Każdy następny rok przynosił widoczne rezultaty. Wystarczy wziąć pod uwagę choćby tylko liczbę młodzieży wychowywanej i kształconej przez zakład.

Pracy tej przeszkodziła pierwsza wojna światowa. Młodzież została usunięta z zakładu. Mimo trudności, z jakimi borykały się wszystkie placówki salezjańskie w czasie wojny, dyrekcja zdołała umieścić część wychowanków w Daszawie, Radnej, w Oświęcimiu i Przemyślu. Przebywali oni tam przez cały czas wojny, a nawet po jej zakończeniu ${ }^{213}$. Dyrekcja schroniska funkcjonowała w zakładzie nieprzerwanie. Dyrektor, ks. Wojciech Balawajder, przeniósł się na stałe do Oświęcimia, by tam lepiej doglądnąć wychowanków krakowskich. Głównym jego zadaniem było zdobycie odpowiednich środków materialnych na utrzymanie umieszczonych w zakładach salezjańskich chłopców. W czasie wojny salezjanie krakowscy zajmowali się administrowaniem i pracą w ogrodzie, który przynosił znaczny dochód.

Tab. nr 20: Dochody i wydatki w ogrodzie fundacji w latach 1916-1920 (w koronach)

\begin{tabular}{|c|c|c|c|}
\hline rok & dochód & wydatki & zysk \\
\hline 1916 & 26.407 .35 & 11.768 .63 & 11.707 .84 \\
\hline 1918 & 87.418 .60 & 36.626 .77 & 50.791 .83 \\
\hline 1919 & 96.976 .30 & 48.630 .85 & 48.345 .45 \\
\hline 1920 & 232.979 .40 & $?$ & $?$ \\
\hline
\end{tabular}

Źródło: ArITSK, A 554 Sprawozdania z czynności schroniska fundacji ks. A. Lubomirskiego za lata 1893-1949, Sprawozdanie dyrekcji za rok 1916, 1918-1920 (bilans dzialu gospodarczego - ogród).

212 ArITSK, T. Schronisko Lubomirskich, S. Wizytatorka do kuratorii 7 VIII 1911 r.

213 ArITSK, T. Schronisko Lubomirskich, Sprawozdania wizytacyjne z roku 1918-1924. 
Sumy te w zupełności wystarczały na utrzymanie wychowanków umieszczonych $w$ innych zakładach salezjańskich na koszl schroniska ${ }^{214}$. Kryzys gospodarczy i inflacja, które wystąpiły po pierwszej wojnie światowej, spowodowały prawie zupełny przepadek kapitału fundacyjnego.

\section{Dochody zwyczajne i madzwyczajne}

W 1925 r. majątek fundacji wynosił 92 tys. zł. Jego procenty dawały rocznie $3.930 \mathrm{zt}^{215}$, gdy tymczasem miesięczne utrzymanie zakładu wynosiło ponad 8 tys. zł. Odsetki zatem wystarczyłyby na funkcjonowanie zakładu zaledwie przez pół miesiąca. Brak opieki konserwacyjno-remontowej spowodował poważne zniszczenie gmachu ${ }^{216}$. Wobec takiego stanu salezjanie trzykrotnie zgłaszali gotowość ustąpienia ze schroniska ${ }^{217}$. Decyzja (1925 r.) przyjęcia pełnej administracji i kierownictwa instytucji dla przeszło setki młodzieży, była krokiem ryzykownym, ale i odważnym. Działalność zakładu oparto na: dochodach $\mathrm{z}$ ogrodu, opłatach pobieranych przy przyjmowaniu do zakładu (wpisowe), subwencjach i odsetkach od kapitału fundacyjnego, zapisach i ofiarach na ręce kuratorii. Liczono także na dochody nadzwyczajne, a więc na pomoc spoleczeństwa i profity z rozmaitych imprez. Brakujące środki zgromadzenie miało zdobywać we własnym zakresie. Tak sprawy te ujmowała umowa, jaką zgromadzenie zawarło $z$ kuratorią w $1924 \mathrm{r}$.

Sytuacja finansowa, szczególnie w pierwszych trzech latach była ciężka. Brakowało środków na utrzymanie sierot. Dyrekcja zwracała się dwukrotnie z prośbą o subwencje do Urzędu Miejskiego m. Krakowa w latach 1925 i 1926. Urząd Miejski nie przyznał takiej zapomogi. Uczynił to dopiero w latach 19271931. Wówczas dyrekcja szkoły rzemieślniczo-przemysłowej, istniejącej w schronisku, otrzymała tytułem zapomogi od władz szkolnych m. Krakowa i z Kasy Oszczędności Krakowa przeszło $30.000 \mathrm{zl}^{218}$.

Schronisko od 1930 r. otrzymywało ponadto subwencje od Ministerstwa Przemysłu i Handlu za pośrednictwem Ministerstwa Wyznań Religijnych i Oświecenia Publicznego, od Urzędu Miejskiego i Krakowskiej Kasy Oszczędności. Zapomogi te byly zróżnicowane co do wysokości.

${ }^{214}$ ArITSK, T. Fundacja Lubomirskiego. Finanse, Sprawozdania 1918-1920.

215 Tamże, Sprawozdanie rachunkowo-kasowe z roku 1925.

${ }^{216}$ ArITSK, B 1303 Kronika w schronisku Lubomirskich 1924-1926 (1925).

${ }^{217}$ ArITSK, T. Lubomirscy. Sprawa przejęcie zakładu przed I i po I wojnie światowej, Ks. Tirone do kuratorii 10 IV $1920 \mathrm{r}$.

${ }^{218}$ ArITSK, T. Lubomirscy. Magistrat Krakowski, Prośba o subwencję 1 X i 8 VII 1926 r., Subwencje Urzędu Miejskiego 1927-1931. 
Tab. nr 21: Subwencje na zakład w latach 1929-1939

\begin{tabular}{|c|c|c|c|}
\hline rok & $\begin{array}{c}\text { Ministerstwo } \\
\text { WRiOP }\end{array}$ & $\begin{array}{c}\text { Urząd } \\
\text { Miasta }\end{array}$ & $\begin{array}{c}\text { Kasa } \\
\text { Oszczędności }\end{array}$ \\
\hline 1929 & 25.000 & 779 & - \\
\hline 1930 & 15.000 & 3.100 & - \\
\hline 1931 & 10.350 & 500 & 1.100 \\
\hline 1932 & 13.150 & 1.400 & - \\
\hline 1933 & 10.000 & 475 & - \\
\hline 1934 & 10.000 & - & - \\
\hline 1935 & 5.000 & - & - \\
\hline 1936 & 11.000 & 500 & - \\
\hline 1937 & - & 175 & - \\
\hline 1938 & 6.000 & 220 & - \\
\hline 1939 & 8.000 & 8.000 & - \\
\hline
\end{tabular}

Źródło: ArITSK, A 554 Sprawozdania z czynności schroniska fundacji ks. A. Lubomirskiego za lata 1893-1949, Sprawozdanie rachunkowe dochodów i wydatków za lata 1931/1932 1938/1939, T.Lubomirscy, Magistrat Krakowski, Zapomogi Ministerstwa Przemysłu i Handlu 1930-1939, Subwencje Urzędu Miejskiego 1930-1939.

W pierwszym roku (1925) dyrektor ks. A. Cieślar urządzał różne imprezy, apelował o pomoc do mieszkańców Krakowa i pomocników salezjańskich ${ }^{219}$. Ostatecznie, trudności przezwyciężono. Wizytujących, z ramienia kuratorii, wprawiał w zdumienie nienaganny sposób funkcjonowania zakładu. Nie mogli zrozumieć, jak można było w tak krótkim czasie uruchomić schronisko i przyjąć taką ilość młodzieży. Być może skłoniło to kuratorię do sfinansowania kosztów elektryfikacji całego gmachu. Pierwszy raz zapaliło się światło w dniu 2 września 1925 r. na pierwszym piętrze, a już 16 września tego roku zakończono zakładanie instalacji w całym zakładzie ${ }^{220}$. Firma Władysława Sojaka, prowadząca te prace, w dużej mierze wykonała je za darmo.

Z doraźną pomocą pospieszyły urzędy miasta i instytucje. Magistrat, dzięki przychylności prezydenta G. Ostrowskiego i wiceprezydenta Karola Rollego, dostarczył 5 ton węgla i zapewnił zniżkę w opłatach za energię elektryczną i wodę. Kurator szkolny Krakowa, Omiński podarował zapasy węgla złożone

${ }^{219}$ Według myśli ks. Bosko pomocnikiem jest ten, kto w jakikolwiek sposób: modlitwą, ofiara czy usługą osobistą dopomaga w rozwoju działalności salezjańskiej. Ustawy $i$ Regulaminy, art. 406-416 (Reg.).

${ }^{220}$ ArITSK, B 1303 Kronika w schronisku Lubomirskich 1924-1926 (16 IX 1925). 
w piwnicach zakładu i 500 zł na przybory szkolne. Zakład salezjański na Dębnikach, zwany „Łosiówką” dostarczał warzyw ze swego ogrodu. Bracia albertyni zaopatrzyli zakład w ziemniaki i drewno. Siostry felicjanki dostarczały komunikanty i reperowały bieliznę kościelną 221 .

Mimo takiej zapobiegliwości kierownictwa zakładu w organizowaniu pomocy odczuwało się braki stałych funduszów. Dla ich uzyskania kuratoria wydzierżawiła w latach 1921-1925 schronisko za sumę 12 tys. zł rocznie. Z tej sumy opłaciła jednak koszty elektryfikacji. W 1931 r. udzieliła ona schronisku subwencji na sumę 15 tys. zł, a w rok później 2.266 zł. Od 1933 r. regularnie wypłacała dyrekcji procenty od kapitału ${ }^{222}$. Pieniądze te pokrywaly średnio $5 \%$ rocznych wydatków schroniska.

Tab. nr 22: Wysokość sum z oprocentowania kapitału zakładowego w latach 19331939

\begin{tabular}{|c|c|}
\hline rok & kwota w zl \\
\hline 1933 & 3.770 .32 \\
\hline 1934 & 3.942 .00 \\
\hline 1935 & 3.973 .31 \\
\hline 1936 & 3.900 .00 \\
\hline 1937 & 3.939 .00 \\
\hline 1938 & 3.938 .00 \\
\hline 1939 & 3.000 .00 \\
\hline
\end{tabular}

Źródło: ArITSK, T. Fundacja Lubomirskiego. Finanse, Sprawozdania finansowe 1933-1939.

Wznowiona w 1925 r. działalność dużego zakładu młodzieżowego, odczuwającego tak dotkliwie braki finansowe, stopniowo rozwijała się. Przyjmowano wyłącznie chłopców starszych, po ukończeniu 14 roku życia. Schronisko miało charakter dobroczynny, a mieściła się w nim bursa, której przyświecały dwa cele: wychowanie i wykształcenie terminatorów. Warunki przyjęcia do bursy musiały ulec zmianie. Kierując się zasadą ks. Bosko: „Nie jest rzeczą słuszną, by korzystał z cudzej dobroczynności ten, kto posiada coś swego", wprowadzono z konieczności w 1926 r. opłaty za pobyt wychowanka. Nie była to sprawa decydująca przy przyjmowaniu, ale istotna. W miarę możliwości wychowankowie płacili do $50 \mathrm{zl}$ miesięcznie, plus $12 \mathrm{zl}$ wpisowego jednorazowo. Opłata za wpisowe nie była zwracana, chociażby uczeń był tylko kilka dni

${ }^{221}$ Kronika. Przegląd dotychczasowej dziatalności w Bursie, „Echo Bursy”, 1 (1926) nr 1, s. 4.

${ }^{222}$ ArITSK, T. Fundacja Lubomirskiego. Finanse, Sprawozdania finansowe za rok 1930 i 1931 . 
w zakładzie. Informowały o tym rodziców prospekty warunków przyjęcia chłopców do bursy. Była to opłata łączna za całkowite utrzymanie w internacie i za naukę pobieraną w zorganizowanych w późniejszych latach szkołach: ogrodniczej i szewskiej.

Tab. nr 23: Opłaty miesięczne wychowanków w latach 1926/1927 - 1937/1938 (w złotych)

\begin{tabular}{|c|c|c|c|c|c|c|c|c|c|c|c|c|}
\hline r. szk. & gratis & 10 & 15 & 20 & 25 & 30 & 35 & 40 & 45 & 50 & $\begin{array}{c}\text { opieka } \\
\text { spo- } \\
\text { leczna }\end{array}$ & ogólem \\
\hline $1926 / 1927$ & 78 & 1 & 2 & 1 & 11 & 10 & - & 3 & - & 15 & 21 & 145 \\
\hline $1928 / 1929$ & 57 & 9 & 6 & 8 & 6 & 15 & 4 & 16 & 5 & 1 & 13 & 139 \\
\hline $1929 / 1930$ & 26 & 2 & - & 7 & 5 & 25 & 3 & 1 & 23 & 13 & 10 & 115 \\
\hline $1930 / 1931$ & 21 & 2 & 1 & 7 & - & 27 & 4 & 2 & 3 & 33 & 25 & 125 \\
\hline $1931 / 1932$ & 15 & 3 & 1 & 2 & 4 & 3 & 22 & 2 & 7 & 21 & 20 & 100 \\
\hline $1934 / 1935$ & 14 & 1 & 6 & 12 & 4 & 7 & 28 & 6 & - & - & 11 & 80 \\
\hline $1937 / 1938$ & 10 & 1 & 4 & 7 & 10 & 14 & 35 & 4 & - & - & - & 90 \\
\hline
\end{tabular}

Źródło: ArITSK, A 532 Schronisko im. ks. A. Lubomirskiego. Pensje chłopców 1928-1938 i długi 1931-1938, Opłaty za utrzymanie w zakładzie w latach 1928/1929 - 1937/1938, A 533 Schronisko im. ks. A. Lubomirskiego. Wykaz wychowanków. Ich pensje. Stałe niedobory, Dyrektor Cieślar do Krajowego Związku Izb i Stowarzyszeń Rękodzielniczego Przemysłu w Krakowie 3 I 1927 r. (prośba o zapomogę).

Prawdopodobnie od 1935 r. opłaty uzależniono od kierunku nauczania. Dla uczniów szkoły ogrodniczej wynosiły one $35 \mathrm{zł}$, dla szewców $20 \mathrm{zl}$, dla pozostałych 40 zł miesięcznie ${ }^{223}$. Bezpłatne utrzymanie wychowanka w bursie w dużej mierze uzależnione było od jego dobrych wyników w nauce i zdyscyplinowania na codzień.

Tab. nr 24: Utrzymanie wychowanków schroniska w latach 1925-1948

\begin{tabular}{|c|c|c|c|}
\hline rok & chłopcy & $\begin{array}{c}\text { sieroty } \\
\text { (gratis) }\end{array}$ & $\begin{array}{c}\text { półsieroty } \\
\text { od 0-50 zf }\end{array}$ \\
\hline $1925 / 1926$ & 120 & 72 & $?$ \\
\hline $1926 / 1927$ & 145 & 59 & 86 \\
\hline $1927 / 1928$ & 142 & 61 & 81 \\
\hline $1928 / 1929$ & 139 & 67 & 72 \\
\hline $1929 / 1930$ & 115 & 58 & 57 \\
\hline
\end{tabular}

${ }^{223}$ Prospekt warunków przyjęcia do Zakładu Salezjańskiego im. Ks. Al. Lubomirskiego „Echo Bursy”, 4 (1929) nr 7-9, s. 7. 


\begin{tabular}{|c|c|c|c|}
\hline $1930 / 1931$ & 125 & $?$ & $?$ \\
\hline $1931 / 1932$ & 100 & $?$ & $?$ \\
\hline $1932 / 1933$ & 91 & 26 & 65 \\
\hline $1933 / 1934$ & 85 & 29 & 36 \\
\hline $1934 / 1935$ & 85 & 22 & 37 \\
\hline $1935 / 1936$ & 106 & 20 & 42 \\
\hline $1936 / 1937$ & 112 & 16 & 44 \\
\hline $1937 / 1938$ & 90 & 14 & 31 \\
\hline $1938 / 1939$ & 74 & 13 & 25 \\
\hline 1948 & 105 & 23 & 35 \\
\hline
\end{tabular}

Źródło: ArITSK, A 554 Sprawozdania z czynności fundacji ks. A. Lubomirskiego za lata 18931949, Sprawozdanie roczne zakładu za lata 1926/1927, 1928/1929, 1930/1931, 1932/1933 1939/1940, 1948.

Tab. nr 25: Sumy opłaty za pobyt w schronisku, w latach 1925/1926 - 1939

\begin{tabular}{|c|c|}
\hline rok & opłaty w zl \\
\hline $1925 / 1926$ & 24.699 .20 \\
\hline 1928 & 25.030 .31 \\
\hline 1929 & 33.357 .56 \\
\hline 1930 & 33.377 .81 \\
\hline 1931 & 28.488 .50 \\
\hline 1932 & 23.489 .45 \\
\hline 1933 & 23.524 .15 \\
\hline 1934 & 24.224 .65 \\
\hline 1935 & 27.846 .61 \\
\hline 1936 & 28.600 .00 \\
\hline 1937 & 32.927 .00 \\
\hline 1938 & 26.583 .59 \\
\hline 1939 & 29.000 .00 \\
\hline
\end{tabular}

Źródło: Sprawozdanie budżetowe za rok 1925, „Echo Bursy”, 1 (1926) nr 9-11, s. 5-7; Sprawoz danie kasowe za rok 1927, „Echo Bursy”, 3 (1928) nr 1-2, s. 4-5; Sprawozdanie kasowe za rok 1928, „Echo Bursy”, 4 (1929) nr 1, s. 4-5; Sprawozdanie kasowe za rok 1929, „Echo Bursy", 5 (1930) nr 1-2, s. 4-5.

W tym miejscu konieczne wydają się dwa wyjaśnienia: w liczbie wychowanków, którzy płacili za swój pobyt w zakładzie ujęte są również sieroty, utrzymywane przez Magistrat Miasta Krakowa lub zarząd miasta, z którego 
chłopiec pochodził, płacąc początkowo stawkę wyznaczoną przez dyrekcję schroniska. Z biegiem lat, jak to widać z niżej zamieszczonej statystyki, władze miejskie zmniejszały ten ryczałt, tłumacząc się potanieniem artykułów pierwszej potrzeby, trudnościami budżetowymi lub uchwałami kolegium gospodarczego urzędu miejskiego, obniżającego ryczałt za żywienie $w$ miejskich zakładach opiekuńczych wychowanków, umieszczonych przez Zarząd Miejski w zakładzie.

Tab. nr 26: Liczba uczniów utrzymywanych na koszt Urzędu Miejskiego w latach $1929-1950$

\begin{tabular}{|c|c|c|c|c|c|}
\hline rok & I kw. & II kw. & III kw. & IV kw. & $\begin{array}{c}\text { stawka } \\
\text { miesięczna } \\
\text { (w zł) }\end{array}$ \\
\hline 1929 & 6 & 6 & 6 & 6 & 50 \\
\hline 1930 & 4 & 4 & 4 & 4 & 50 \\
\hline 1931 & 17 & 22 & 22 & 19 & 50 \\
\hline 1932 & 16 & 16 & 14 & 14 & 45 \\
\hline 1933 & 14 & 14 & 14 & 14 & 43 \\
\hline 1934 & 11 & 11 & 6 & 6 & 41 \\
\hline 1935 & 4 & 5 & 5 & 5 & 37 \\
\hline 1938 & 8 & 8 & 8 & 8 & 32 \\
\hline 1946 & - & - & 3 & 6 & - \\
\hline 1947 & 19 & 26 & 26 & 6 & - \\
\hline 1948 & 18 & 18 & 18 & 18 & - \\
\hline 1949 & 19 & 19 & 19 & 19 & - \\
\hline 1950 & 19 & 20 & 19 & 19 & - \\
\hline
\end{tabular}

Źródło: ArITSK, A 534 Schronisko im. A. Lubomirskiego. Wykaz wychowanków na utrzymaniu: Wydziału Powiatowego, Kuratorium - Wydział Opieki, Skarbu Państwa 1947/48/49/50, Wykaz dzieci będących na utrzymaniu Skarbu Państwa w latach 1946-1950.

Wiele zakładów salezjańskich po pierwszej wojnie światowej nie posiadało stałych funduszy na utrzymanie, wyjąwszy w niektórych przypadkach, kilka hektarów ziemi. Chłopcy, przeważnie ubodzy, nic nie płacili, albo bardzo mało, tak że suma uzyskana $z$ ich opłat nie pokrywała nawet kosztów zakupu samego chleba. Tak było np. w Oświęcimiu w 1929 roku $^{224}$. Podobnie przedstawiała się sprawa w schronisku fundacji księcia Lubomirskiego.

${ }^{224}$ List Ks. Dr. Piotra Tironego, Inspektora XX. Salezjanów do Pomocników Salezjańskich, PS, 6 (1922) nr 4, s. 3. 
Tab. nr 27: Zestawienie wpływów i koszty utrzymania w latach 1925-1929

\begin{tabular}{|c|c|c|}
\hline rok & $\begin{array}{c}\text { wpisowe i opłata } \\
\text { za utrzymanie w zł }\end{array}$ & $\begin{array}{c}\text { koszty utrzymania } \\
\text { (prowiant) w zl }\end{array}$ \\
\hline $1925 / 1926$ & 24.699 .20 & 62.456 .00 \\
\hline 1927 & 25.720 .10 & 63.503 .74 \\
\hline 1928 & 25.030 .31 & 60.438 .68 \\
\hline 1929 & 33.377 .81 & 53.389 .54 \\
\hline
\end{tabular}

Źródło: Sprawozdanie budżetowe za rok 1925, „Echo Bursy”, 1 (1926) nr 9-10, s. 5-7; Sprawozdanie kasowe za rok 1927, „Echo Bursy”, 3 (1928) nr 1-2, s. 4-5; Sprawozdanie kasowe za rok 1928, „Echo Bursy”, 4 (1929) nr 1-2, s. 3-4; Sprawozdanie kasowe za rok 1929, „Echo Bursy", 5 (1930) nr 1-2, s. 3-4.

Ponadto w latach 1948-1950 znaczna liczba wychowanków schroniska korzystała ze stypendiów Kuratorium Oświaty miasta Krakowa.

Tab. nr 28: Wychowankowie utrzymywani przez Kuratorium w latach 1948-1950

\begin{tabular}{|c|c|}
\hline rok & liczba wychowanków \\
\hline 1948 & 40 \\
\hline 1949 & 37 \\
\hline 1950 & 36 \\
\hline
\end{tabular}

Źródło: ArITSK, T. Lubomirscy. Kuratorium Szkolne Krakowskie, Lista wychowanków utrzymywanych w zakładzie Lubomirskich 1948-1950, A 534 Schronisko im. A. Lubomirskiego. Wykaz wychowanków na utrzymaniu: Wydziału Powiatowego, Kuratorium - Wydzial Opieki, Skarbu Państwa 1947/48/49/50, Wykaz dzieci będących na utrzymaniu Kuratorium Okręgu Szkolnego Krakowskiego w roku szkolnym 1948/1949, 1949/1950.

Ostatnimi źródłami dochodów zwyczajnych były: ogród, gospodarstwo i zapomogi, jakie dyrekcja otrzymywała od prowincjała ${ }^{225}$. W sprawozdaniach finansowych z tych lat nie zawsze sumy te były wyszczególnione oddzielnie.

Tab. nr 29: Dochody własne i zapomogi z Inspektoratu salezjańskiego w Krakowie w latach 1925-1939

\begin{tabular}{|c|c|c|}
\hline rok & własne w zł & z Inspektoratu w zł \\
\hline $1925 / 1926$ & 20.485 .66 & - \\
\hline 1927 & 15.961 .96 & 4.000 .00 \\
\hline 1928 & 24.125 .09 & 13.000 .00 \\
\hline
\end{tabular}

225 ArTTSK, T. Fundacja Lubomirskiego. Finanse, Sprawozdanie finansowe 1930-1939, 19461950, T. Szkoła szewska. Lubomirskich, Sprawozdanie rachunkowe za rok 1928. 


\begin{tabular}{|c|c|c|}
\hline 1929 & 20.648 .95 & 1.700 .00 \\
\hline 1930 & 27.842 .56 & 3.900 .00 \\
\hline 1931 & 21.326 .00 & 1.500 .00 \\
\hline 1932 & 24.750 .28 & 2.200 .00 \\
\hline 1933 & 27.245 .98 & 4.000 .00 \\
\hline 1934 & 23.669 .55 & 900.00 \\
\hline 1935 & 24.396 .18 & - \\
\hline 1936 & 25.500 .00 & - \\
\hline 1937 & 27.709 .50 & - \\
\hline 1938 & 38.598 .58 & - \\
\hline 1939 & 28.400 .00 & - \\
\hline
\end{tabular}

Źródło: ArITSK, A 554 Sprawozdania z czynności schroniska fundacji ks. A. Lubomirskiego za lata 1893-1949, Rachunki dochodów i wydatków na utrzymanie zakładu w okresie sprawozdawczym 1932/1933 - 1938/1939.

Znacznym wsparciem finansowym chociaż doraźnym były dochody czerpane $z$ różnych imprez takich, jak: festyny (wiosenne w maju i jesienne we wrześniu), okazyjne składki, loterie, a przede wszystkim widowiska teatral$\mathrm{e}^{226}$. Niejednokrotnie trudno dziś ustalić, która impreza jaki dawała dochód. W bilansach łączono je $z$ ofiarami osób prywatnych. Można jednak znaleźć kilka informacji, dotyczących poszczególnych imprez, których drobiazgowe omawianie wyda się tutaj niekonieczne. Imprezy te przynosiły także pewien dochód.

Tab. nr 30: Dochody z imprez w latach 1925-1939

\begin{tabular}{|c|c|}
\hline rok & kwota w zl \\
\hline $1925 / 1926$ & 9.481 .70 \\
\hline 1927 & 6.614 .69 \\
\hline 1928 & 8.721 .34 \\
\hline 1929 & 9.119 .29 \\
\hline 1930 & 6.409 .93 \\
\hline 1931 & 2.348 .90 \\
\hline 1934 & 2.237 .41 \\
\hline 1936 & 2.000 .00 \\
\hline
\end{tabular}

${ }^{226}$ ArITSK, T. Fundacja Lubomirskiego. Finanse, Sprawozdanie finansowe 1930-1938. 


\begin{tabular}{|l|l|}
\hline 1937 & 1.544 .96 \\
\hline 1938 & 1.875 .20 \\
\hline 1939 & 200.00 \\
\hline
\end{tabular}

Źródło: ArITSK, A 554 Sprawozdania z czynności schroniska fundacji ks. A. Lubomirskiego za lata 1893-1949, Rachunek dochodów i wydatków na utrzymanie zakladu w okresie sprawozdawczym 1933/1934-1938/1939; Sprawozdanie kasowe za rok 1925/1926, „Echo Bursy”, 1 (1926) nr 9-11, s. 5-7; Sprawozdanie kasowe za rok 1927, „Echo Bursy”, 3 (1928) nr 1-2, s. 4-5; Sprawozdanie kasowe za rok 1928, „Echo Bursy”, 4 (1929) nr 1-2, s. 4-5; Sprawozdanie kasowe za rok 1929, „Echo Bursy”, 5 (1930) nr 1-2, s. 4-5.

Tab. nr 31: Zestawienie finansowe zakładu w latach 1926-1950

\begin{tabular}{|c|c|c|c|}
\hline rok & wydatki & wpływy & zadłużenie \\
\hline 1926 & 125.663 .73 & 103.975 .43 & 21.688 .30 \\
\hline 1927 & 134.665 .57 & 113.774 .37 & 20.891 .20 \\
\hline 1928 & 150.926 .17 & 133.100 .45 & 17.825 .72 \\
\hline 1929 & 132.817 .82 & 110.713 .56 & 22.104 .26 \\
\hline 1930 & 114.478 .82 & 109.675 .28 & 4.803 .54 \\
\hline 1931 & 85.210 .28 & 76.124 .42 & 9.085 .86 \\
\hline 1932 & 71.261 .65 & 68.366 .71 & 2.894 .94 \\
\hline 1933 & 67.679 .43 & 63.351 .88 & 4.327 .55 \\
\hline 1934 & 66.116 .24 & 62.581 .38 & 3.534 .86 \\
\hline 1935 & 66.877 .56 & 64.533 .00 & 2.344 .50 \\
\hline 1936 & 74.162 .59 & 69.118 .09 & 4.944 .50 \\
\hline 1937 & 67.259 .96 & 63.915 .98 & 3.343 .98 \\
\hline 1938 & 79.665 .67 & 75.481 .74 & 4.183 .93 \\
\hline 1939 & 47.511 .98 & 43.423 .16 & 4.088 .82 \\
\hline 1940 & 53.610 .32 & 53.401 .92 & 208.40 \\
\hline 1941 & 69.961 .74 & $?$ & $?$ \\
\hline 1942 & 98.978 .47 & $?$ & $?$ \\
\hline 1946 & 1.203 .132 .70 & 951.738 .70 & 251.394 .00 \\
\hline 1947 & 4.057 .736 .27 & 1.017.921.27 & 3.039 .815 .00 \\
\hline 1948 & 5.321 .284 .38 & $?$ & $?$ \\
\hline 1949 & 5.507 .862 .00 & $?$ & $?$ \\
\hline
\end{tabular}

Źródło: ArITSK, A 554 Sprawozdania z czynności schroniska fundacji ks. A. Lubomirskiego za lata 1893-1949, Rachunki dochodów i wydatków na utrzymanie zakładu w okresie sprawozdawczym 1932/1933-1938/1939, T. Fundacja Lubomirskiego. Finanse, Sprawozdania kasowe 1926-1951; Sprawozdanie kasowe za rok 1928, „Echo Bursy”, 4 (1929) nr 1-2, s. 4 5; Sprawozdanie kasowe za rok 1929, „Echo Bursy”, 5 (1930) nr 1-2, s. 4-5. 
Należy też wspomnieć o zapomogach i pomocy osób prywatnych imiennych i anonimowych. Jedynie dzięki pomocy tych ofiarnych ludzi zdołało schronisko funkcjonować w najtrudniejszych latach dwudziestych wówczas, gdy wznawiało swoją pracę wychowawczą. Już w lipcu 1926 r., po dziesięciomiesięcznych zmaganiach z trudnościami, pierwszy raz, oficjalnie, przez swój biuletyn „Echo Salezjańskiej Bursy fund. Ks. Al. Lubomirskiego w Krakowie”, dyrekcja zwróciła się o pomoc do społeczeństwa ${ }^{227}$. Przedstawiła mu, że dzienne utrzymanie schroniska wynosi około $250 \mathrm{zł}$; miesięcznie zamyka się to sumą 10 tys. zł. Dotychczasowe długi wynosiły 8.200 zł. Apelowano więc do ludzi dobrej woli o pomoc. Odpowiedzią na apel ,wszystko się przyda”, była spora liczba dobrodziejów. Profesor Artur Zawadzki urządził w sali Starego Teatru „Wieczór humoru i śmiechu”, z którego dochód w wysokości 109 zł ofiarowal na cele bursy. Centralny Związek Ogrodników, z dochodu olbrzymiej loterii kwiatowej złożył 344 zł. Euszczarnie i młyny krakowskie przysłały 25 q mąki. Dyrektor Zakrzewski z Polskiego Towarzystwa Handlowego przysłał $100 \mathrm{~kg}$ powideł. Komitet Wojewódzki Opieki nad Zakładami Sierocymi, którego celem było niesienie pomocy najbardziej potrzebującym zakładom charytatywnym Krakowa, zobowiązał się, że w 1926 r. szczególnie będzie dopomagał finansowo bursie ${ }^{228}$.

Dary te i ofiary, sięgające od kilku zaledwie złotych do kilku tysięcy zl, wpływały dzięki życzliwości dra Güntlera, który co niedzielę w „Ilustrowanym Kurierze Codziennym" uświadamiał społeczeństwu potrzeby schroniska. W ten sposób zdobyte i skumulowane, najdrobniejsze choćby sumy, urastały do znacznej wysokości i dopełniały brakujące złotówki, wyszczególnione w ostatnim zestawieniu jako zadłużenie schroniska.

\section{ROZDZIAL IV \\ FORMY DZIAŁALNOŚCI WYCHOWAWCZO-OŚWIATOWEJ}

Życie w zakładzie było inspirowane przez działalność rożnorodnych organizacji młodzieżowych. Organizacje te, zwane towarzystwami, pobudzały wychowanków do współzawodnictwa, wyrabiały w nich poczucie samodzielności i wyzwalały pozytywne postawy społeczne. Miały one charakter religijny, samokształceniowy, artystyczny lub sportowy ${ }^{229}$.

${ }^{227}$ Schronisko w potrzebie, „Echo Bursy”, 1 (1926) nr 7-8, s. 4; Po roku pracy, „Echo Bursy”, 1 (1926) nr 9-11, s. 3.

${ }^{228}$ ArITSK, T. Fundacja Lubomirskiego. Finanse, Wojewódzki Komitet Opieki do fundacji ks. Lubomirskiego 12 II 1926 r.

${ }^{229}$ ArITSK, T. Schronisko Lubomirskich, Sprawozdanie lekarskie z roku 1926. 


\section{Towarzystwa o charakterze religijnym}

W procesie wychowania, zgodnie z zaleceniami swego założyciela - ks. J. Bosko, salezjanie przywiązywali duże znaczenie do stowarzyszeń religijnych. Celem ich było podtrzymanie ducha pobożności. Młodzież, ucząca się rzemiosła, skupiała się w Towarzystwie św. Józefa. Pierwsze takie towarzystwo, na terenach polskich, powstało w salezjańskiej szkole zawodowej w Oświęcimiu w 1902 roku $^{230}$.

Do najbardziej popularnych towarzystw religijnych w zakładach salezjańskich trzeba także zaliczyć: Towarzystwo Niepokalanej, Towarzystwo św. Józefa i koło misyjne, propagujące idee misji wśród wychowanków i społeczeństwa. Koło takie przodowało we wspomnianym współzawodnictwie w schronisku. Nosiło ono nazwę Towarzystwa Młodzieży Misyjnej im. kard. Jana Cagliero $^{231}$. Liczyło 25 członków. Impuls do jego założenia zrodził się pod wpływem jubileuszu 50-lecia pracy misji salezjańskich, obchodzony 25 kwietnia 1926 r. Na tę okoliczność przygotowano „dzień misyjny”. Obchody jubileuszowe zaszczycił swoją obecnością abp Adam Sapieha ${ }^{232}$.

Członkowie tego towarzystwa wzięli udział w zlocie misyjnym, zorganizowanym 14 marca 1926 r. w Zakładzie ks. Siemca w Warszawie. Cel zlotu określony był w haśle: „Organizujemy kółka młodzieży misyjnej”233. Przygotował on materiały do Ogólnopolskiego Salezjańskiego Kongresu Misyjnego w Łodzi, odbytego 9 maja 1926 r. Wzięło w nim udział ponad 6 tys. wychowanków. W rezolucji kongresu młodzież wzywała do modlitwy w intencji misji, urządzania konferencji z odczytami o tematyce misyjnej. Postulowano też, aby uczniowie szkół rzemieślniczych wykonali przedmioty, które miały być najpierw eksponowane na specjalnej wystawie, a później wysyłane do misji salezjańskich $^{234}$. Towarzystwo misyjne jak i wszystkie organizacje religijne istniejące na terenie zakładu powierzone były opiece katechety, czyli wychowawcykapłana, czuwającego nad życiem religijnym i moralnym, a także odpowiedzialnego za zdrowie fizyczne wychowanków ${ }^{235}$.

${ }^{230}$ ArITSK, T. Oświęcim. Szkoła Rzemiosł, Odpowiedź na ankietę wystosowaną do kierowników szkół zawodowych.

${ }^{231}$ ArITSK, T. Zakład Lubomirskich. Organizacje młodzieżowe, Protokoły Towarzystwa Misyjnego na rok 1926.

${ }^{232}$ ArITSK, B 1303 Kronika w schronisku Lubomirskich 1924-1926 (10-25 V 1926); Tow. Mlodzieży Misyjnej, „Echo Bursy”, 1 (1926) nr 3-4, s. 5.

${ }^{233}$ Dziesięciolecie działu grafiki Salezjańskiej Szkoty Rzemiost w Warszawie 1923-1933, Warszawa 1933, s. 21; Kongres misyjny mtodzieży w warszaw. Zakt. Salez., PS, 10 (1926) nr 4, s. 46; Z kroniki naszych zaktadów, PS, 10 (1926) nr 4, s. 46, nr 5, s. 61.

${ }^{234}$ Przebieg Kongresu misyjnego w Lodzi: Rezolucje, PS, 10 (1926) nr 6-8, s. 104-105.

${ }^{235}$ Ustawy i Regulaminy, art. 133, 186 i 189 (Reg.). 
Cel, jaki sobie wytyczyło Towarzystwo Młodzieży Misyjnej im. kard. Jana Cagliero działające w schronisku, można streścić w dwóch punktach: zapoznanie jak najszerszych kręgów społeczeństwa, a przede wszystkim młodzieży, z działalnością misyjną i konkretna pomoc materialna na rzecz misji. Pierwszy $z$ nich osiagano przy pomocy tzw. dni misyjnych, organizowanych kilka razy w roku. Dzień misyjny rozpoczynano uroczystą mszą św., celebrowaną w kaplicy zakładowej przez abpa Adama Sapiehę, podczas której arcypasterz wygłaszał okolicznościową homilię. Następnie członkowie towarzystwa prezentowali $w$ auli referaty na przemian z przemówieniami zaproszonych przedstawicieli władz kościelnych i państwowych. Referaty stanowiły podstawę do prac przygotowawczych w kilku sekcjach tematycznych. Po wspólnej dyskusji formułowano wytyczne i podejmowano postanowienia na przyszłość.

Ostatnią, trzecią część dnia misyjnego, wypełniały występy artystyczne, przygotowane przez wychowanków ze schroniska, a także zaproszonych $\mathrm{z}$ innych zakładów, bądź też z krakowskich domów młodzieżowych ${ }^{236}$. Część artystyczna odbywała się w sali teatralnej zakładu, lub na scenie teatru Domu Żołnierza Polskiego, wypożyczanej specjalnie na ten cel. Składały się na nią występy i deklamacje, a także sztuka sceniczna, która była końcowym akcentem „dnia misyjnego”.

Dni misyjne stały się właściwą propagandą misji katolickich. I tak $25 \mathrm{kwiet}-$ nia 1926 r. powzięto rezolucję, by każdy uczestnik pozyskał dla jednego $\mathrm{z}$ czasopism misyjnych, które ukazywały się w tym czasie, przynajmniej trzech abonentów w ciągu roku ${ }^{237}$. Przyjęto pozytywnie projekt ks. rektora Mieczysława Kuznowicza, aby zakładać koła misyjne $z$ centralą w schronisku im. A. Lubomirskiego. Hasłem drugiego ,wieczoru misyjnego" 12 czerwca $1926 \mathrm{r}$. była konkretna pomoc dla misji. W tym celu umieszczono przy bramie wejściowej do schroniska skarbonkę. Każdy gość, biorący udział w „dniu misyjnym”, miał okazję do udzielenia wsparcia materialnego. Ten wieczór był prezentacją idei misyjnej dla mieszkańców Krakowa. Wcześniej orkiestra zakładowa dęta przeszła przez miasto, zapraszając do przybycia na imprezę misyjną ${ }^{238}$.

Towarzystwo misyjne nie ograniczało jednak tej pomocy tylko do płaszczyzny materialnej. Istniał $w$ zakładzie tzw. misyjny skarbczyk duchowy, w którym członkowie towarzystwa i wychowankowie zapisywali akty modlitewne na intencję misji ${ }^{239}$.

${ }^{236}$ Wychowankowie schroniska utrzymywali bliskie stosunki z wychowankami innych zakładów wychowawczych: im. ks. Mieczyslawa Kuznowicza, braci albertynów, księży pijarów. Młodzież nasza przy pracy misyjnej, „Echo Bursy”, 1 (1926) nr 5-6, s. 2-4.

237 ArITSK, T. Zakład Lubomirskich. Organizacje młodzieżowe, Protokół z posiedzenia z 25 IV $1926 \mathrm{r}$.

${ }^{238}$ ArITSK, B 1303 Kronika w schronisku Lubomirskich 1924-1926 (12 VI 1926).

${ }^{239} Z$ życia mtodzieży w Zaktadzie. Koto amatorskie. „Echo Bursy”, 3 (1928) nr 3-4, s. 4-5. 
Elementem mobilizującym członków towarzystwa było poświęcenie sztandaru misyjnego. Sztandar ten został wykonany w pracowni Marii Mayberg „Marta”. Na awersie było wypisane hasło: „Przyjdź Królestwo Twoje”, oplatające białą gołębicę. Symboliczny zaś obraz, pędzla Szczurowskiego, zdobił jego odwrotną stronę. Metropolita krakowski Adam Sapieha poświęcił sztandar w święto Niepokalanej 8 grudnia 1926 roku $^{240}$. W przemówieniu wygłoszonym z tej okazji mówca podkreślił żywą działalność towarzystwa, które już po ośmiu miesiącach swego istnienia potrafiło ufundować sztandar, pierwszy misyjny sztandar w Polsce. Uczestnictwo metropolity krakowskiego w tej uroczystości, jak i telegramy bpa Antoniego Juliana Nowowiejskiego z Płocka, prezesa Generalnego Związku Misyjnego w Polsce oraz bpa Anatola Nowaka, ordynariusza przemyskiego dobitnie świadczą o żywej działalności towarzystwa i randze uroczystości. W dniu tym odznaki misyjne otrzymało 28 nowo przyjętych członków ${ }^{241}$.

Kolejnym wydarzeniem, zasługującym na odnotowanie, było otwarcie czytelni czasopism i książek misyjnych, z której mogli korzystać wszyscy mieszkańcy zakładu. Redakcje polskich czasopism misyjnych, uwzględniając położenie materialne placówki wychowawczej, nadsyłały co miesiąc, bezpłatnie swe wydawnictwa, a mianowicie: „Misje Katolickie” jezuici krakowscy, „Nasz Misjonarz” werbiści z Grudziądza, „Pobudka Misyjna” szare urszulanki z Pniew w Poznańskim, "Oblat Niepokalanej” oblaci z Krobi Wielkopolskiej, „Echo z Afryki” i „Murzynek” Sodalicja św. Piotra Klawera z Krakowa, „Królowa Apostołów” i „Mały Apostoł” pallotyni z Wadowic, „Wiadomości Misyjne" księża misjonarze mariańscy, „Pokłosie Salezjańskie” z Warszawy, „Posłaniec Matki Boskiej Saletyńskiej” saletyni z Dembowca, „Posłaniec Św. Rodziny" księża misjonarze z Góry Klasztornej. W sumie przysyłano 12 czasopism oraz „Młodzież Misyjną”, którą prenumerowali wszyscy członkowie Towarzystwa Misyjnego ${ }^{242}$.

Towarzystwo prowadziło działalność nie tylko w schronisku, ale udzielało się także na zewnątrz. I tak w lutym 1926 r. przybyła do zakładu grupa chłopców z siódmej klasy Szkoły Podstawowej św. Mikołaja w Krakowie, którzy pragnęli zapoznać się z działalnością towarzystwa misyjnego, a następnie zadeklarowali swój akces. Dyrektor ks. Cieślar jeszcze w 1926 r. zdecydował się utworzyć drugie towarzystwo misyjne $\mathrm{z}$ nieco zmodyfikowanym celem, które przyjęło imię św. Dominika Savio. Liczyło ono 12 członków. Dnia 5 maja tego roku kl. Dominik Lape wraz z członkami Koła Misyjnego im. Dominika Savio,

${ }^{240}$ Pamiqtka Dnia Mlodzieży Misyjnej w Krakowie, red. ks. A. Ogórkiewicza, Kraków 1927, s. 15 .

${ }^{241}$ Poświęcenie pierwszego sztandaru misyjnego w Polsce, „Echo Bursy”, 1 (1926) nr 12, s. 2-6.

242 Tamże, s. 4. 
przygotował przedstawienie teatralne pt. „Wenancjusz”. W roku następnym przyjęło dalszych 6 członków ${ }^{243}$.

Propaganda misyjna, podjęta od początku działalności salezjanów w schronisku, rozszerzała się na nowe tereny. Wyrazem tego było założenie towarzystw misyjnych w Świątnikach i Rakowicach pod Krakowem. Towarzystwo w Świątnikach przybrało imię ks. Jana Bosko, a zawiązało się w styczniu 1927 r. pod patronatem miejscowego proboszcza, ks. Józefa Międziołka i inż. Fryderyka Klementysa, dyrektora miejscowej szkoły ślusarskiej. Towarzystwo Misyjne im. św. Józefa Kalasantego w kolegium księży pijarów na Rakowicach powstało w lutym 1927 roku $^{244}$. Oba towarzystwa przyjęły statut Towarzystwa Młodzieży Misyjnej im. kard. Cagliero, z zebraniami co dwa tygodnie, referatami, skarbonką misyjną i skarbczykiem duchowym.

Członkowie towarzystwa przy schronisku, celem zdobycia odpowiednich środków materialnych, zorganizowali sprzedaż i wysyłkę znaczków misyjnych. Ponadto zobowiązali się wykonać drobne przedmioty w zakresie rzemiosł: ślusarskiego, introligatorskiego, krawieckiego i szewskiego, które po sprzedaniu przyniosły dochód przeznaczony dla misjonarzy ${ }^{245}$.

Towarzystwo obchodziło uroczyście rocznicę śmierci swego patrona, a zarazem największego misjonarza salezjańskiego kard. J. Cagliero w dniu 28 lutego $1927 \mathrm{roku}^{246}$. Wieczorek misyjny, poświęcony uczczeniu tej rocznicy, wypełniły deklamacje, śpiewy, występy orkiestry i odczyty o życiu i działalności wielkiego kardynała i salezjańskiego pioniera pracy misyjnej. Zainicjowane obchody stały się tradycją w latach następnych.

\section{Towarzystwa i kółka zainteresowań}

W placówkach salezjańskich dużą popularnością cieszyły się kółka o charakterze artystycznym, a zwłaszcza teatrzyk amatorski. Jego wartość doceniał również ks. Jan Bosko. Teatr miał wychowywać, służyć podnoszeniu poziomu moralności wśród młodzieży i wreszcie bawić ${ }^{247}$. Wystawiano w nim sztuki o tematyce religijnej, patriotycznej, dydaktycznej i etycznej.

243 ArTTSK, B 1303 Kronika w schronisku Lubomirskich 1924-1926 (5 V 1926); Pamiątka Dnia Mtodzieży, s. 26.

244 ArITSK, T. Dyrekcja zakładu Lubomirskich, Ks. Cieślar do kuratorii 21 III 1927 r.; Pamiqutka Dnia Mtodzieży, s. 23.

${ }^{245}$ ArITSK, T. Zakład Lubomirskich. Organizacje młodzieżowe, List ks. J. Siary do Towarzystwa Młodzieży Misyjnej im. kard. J. Cagliero w schronisku z 28 XI 1927 r.

246 Tamże, Protokól z uroczystości ku czci kard. J. Cagliero z 28 II 1927 r.

${ }^{247}$ Ustawy i Regulaminy, art. 237-246 (Ust.); P. B raido, System wychowawczy księdza Bosko, Warszawa 1971, s. 49-50. 
Geneza amatorskiego teatrzyku w schronisku była inna niż w pozostałych zakładach salezjańskich. Otóż wywodził się on z Towarzystwa Sportowego „Orlęta”, założonego w fundacji 16 września $1925 \mathrm{roku}^{248}$. Towarzystwo to dzieliło się na sekcje: dramatyczną, sportową i muzyczną. Większość członków pochodziła spoza zakładu i należała do tutejszego oratorium. Młodzież ta przychodziła do zakładu wieczorem na wspólne gry, ćwiczenia muzyczne, próby sceniczne, czytanie książek, konferencje i odczyty. Towarzystwo liczyło wówczas 86 członków. Lata 1926-1929 stanowią okres szczególnie prężnej działalności „Orląt”. Prezesem był Mariusz Fetter, a wiceprezesem inżynier Artur Szymański. Prezes, jako pomocnik salezjański, był oddanym społecznikiem. Twierdził, że kilka godzin spędzonych po pracy zawodowej wśród młodzieży to czas najlepiej wykorzystany ${ }^{249}$. Sekcja teatralna była ważnym ogniwem towarzystwa. $\mathrm{Na}$ długiej liście sztuk teatralnych bezsprzecznie na czoło wysunęły się „Jasełka” i misterium „Obrazy Męki Pańskiej”. W przedstawieniu jasełek posługiwano się początkowo tekstem Lucjana Rydla „Betlejem Polskie". Do nich nawiązał ks. Antoni Hlond, który napisał nowy tekst, ubogacony kolędami, pastorałkami i podkładem muzycznym. Przygotowane przez kl. Zygmunta Kuzaka i grane w roku szkolnym 1926/1927 cieszyły się ogromnym powodzeniem w krakowskim środowisku ${ }^{250}$. Obejrzało je kilka tysięcy ludzi, a wśród nich alumni seminariów duchownych diecezjalnych: krakowskiego, śląskiego i częstochowskiego oraz księży pijarów z Rakowic i Krakowa, księży salezjanów (instytut filozoficzny) z Krakowa, Komitet Opieki nad Zakładami Sierocymi i mistrzowie terminatorów wraz z rodzinami, u których wychowankowie salezjańscy praktykowali. Brak środków nie pozwalał na urządzenie sceny, jakiej wymagały same sztuki ${ }^{251}$.

Dyrektor Teatru Bagatela w Krakowie Gawlikowski w 1927 r. udostępnił nieodpłatnie scenę dla publiczności na odegranie Jasełek. W następnym roku grano dodatkowo gościnnie na scenie Domu Żołnierza Polskiego w Krakowie. O zapotrzebowaniu na tego rodzaju sztukę religijną świadczy ilość wystawianych spektakli: w 1925 r. grano 8 przedstawień, w 1926 r. - dziesięć, w 1927 r. dziewięć, w 1928 r. - dwadzieścia osiem, w 1931 r. - piętnaście i w 1937 r. osiem.

Przed premierą w 1928 r. kapela zakładowa, przebrana za krakowiaków, przeszła przez miasto reklamując jasełka. Również zachęcano do ich obejrzenia poprzez fale radiowe. Skutek był taki, że jak nigdy dotychczas i w latach późniejszych, wystawiono przeszło podwójną ilość spektakli. Premiera odby-

\footnotetext{
${ }^{248}$ ArITSK, B 1303 Kronika w schronisku Lubomirskich 1924-1926 (21 IX 1925).

${ }^{249}$ Z nowym rokiem, „Echo Bursy”, 2 (1927) nr 1-2, s. 4.

${ }^{2501} J a s e t k a$, „Echo Bursy”, 2 (1927) nr 1-2, s. 7.

${ }^{251}$ Sprawozdanie budzetowe za rok 1925/1926, „Echo Bursy”, 1 (1926) nr 9-11, s. 5.
} 
wała się w święto św. Szczepana, a kończono zazwyczaj w święto Matki Bożej Gromnicznej. Nie było stałego reżysera do ich przygotowywania. Tego zadania podejmowali się zarówno klerycy - asystenci, jak i salezjanie, pełniący funkcje przełożonych w zakładzie. W 1927 r. przygotował je asystent schroniska kl. Zygmunt Kuzak, w 1932 r. - ks. Alojzy Sękowski (prefekt), w 1934 r. kl. Władysław Chmiel (teolog z „Łosiówki”), w 1935 r. - ks. Jan Domino (radca zakładu). Stosowano niekiedy praktykę (1932 r.), że próba generalna była zarazem spektaklem granym wyłącznie dla dzieci za wolnym wstępem. $\mathrm{Na}$ późniejsze przedstawienia, w takim wypadku, najmłodszych nie wpuszczano, by nie przeszkadzały dorosłej widowni nieodpowiednim zachowaniem. Role w przedstawieniach obsadzane były wychowankami zakładu. Zdarzało się, że z konieczności ważniejsze role grali klerycy salezjańscy studiujący na „Łosiówce". Przestarzałe wyposażenie sceny teatralnej wymagało znacznych nakładów finansowych. Częściowo prac tych podjął się w grudniu 1932 r. ówczesny prefekt ks. Sękowski. Reżyserując w tym roku jasełka, wyposażył scenę w nową dekorację, ulepszył i zmodernizował jej oświetlenie, a widownię zaopatrzył w nowe krzesła ${ }^{252}$.

Drugim przedstawieniem, które cieszyło się wielką popularnością, było misterium „Obrazy Męki Pańskiej”. Opierało się ono na tekście sztuki „Nazareńczyk" ks. Stanisława Hopka. W 1930 r. nowy scenariusz na role, wyłącznie męskie, napisał salezjanin, ks. Franciszek Harazim, a ks. Antoni Hlond (Chlondowski) skomponował muzykę ${ }^{253}$.

Misterium to wystawiano każdego roku w Wielkim Poście. Kolejną sztuką o tematyce pokutnej była „Pałka Madeja”. Przedstawienie to wszakże nie cieszyło się odpowiednią frekwencją w porównaniu z misterium pasyjnym, chociaż grane było również każdego roku. Dlatego grano ją tylko kilka razy $^{254}$.

Występy teatru na scenie zakładowej uświetniały akademie na okoliczność rozpoczęcia i zakończenia roku szkolnego, z okazji imienin przełożonych placówki, upamiętniające święta kościelne i państwowe. Organizowano też imprezy w celu zdobycia środków finansowych dla zakładu. Były one okazją do ukazania dorobku scenicznego, a jednocześnie stwarzały uczestnikom możliwość przeżyć religijnych. O prężnej działalności sekcji dramatycznej może świadczyć fakt, że już w dwa miesiące po jej założeniu, wystawiono pierwszą sztukę sceniczną pt. „Stanko powstaniec”. Był to dramat w trzech aktach, napisany przez ks. Franciszka Harazima. Odegrano go na akademii ku czci św. Stanisława Kostki, patrona młodzieży, w dniu 13 listopada 1925 r. Bilans

252 ArITSK, B 1504 Schronisko Lubomirskich. Kronika 1927-1950 (1 I - 2 II 1927, 26 XII 1927 - 3 II 1928, 26 XII 1928 - 12 II 1929, XII 1932).

${ }^{253}$ Z. Mali n ow s ki, Dziatalność muzyczna salezjanów polskich, w: 75-lecie, s. 115.

${ }^{254} Z$ życia mtodziézy w zaktadzie. Koło amatorskie, „Echo Bursy”, 3 (1928) nr 3-4, s. 5. 
pierwszego roku działalności sekcji zamknął się wystawieniem 29 przedstawień teatralnych i urządzeniem 5 akademii ${ }^{255}$.

Teatr zakładowy, przed przystąpieniem do przygotowywania jakiejś sztuki, uwzględniał charakter uroczystości, na której miała ona być prezentowana. Z okazji święta misyjnego przygotowywano przedstawienia o tematyce misyjnej, np. „W Patagonii” ks. F. Harazima (przeróbka z włoskiego). Zakończenie tygodnia wstrzemięźliwości, organizowanego przez zakładowe koło abstynentów, uświetniała sztuka „Uratowany”. Dla żołnierzy grano sztukę „Dwaj Sierżanci”. W karnawale wystawiano operetki: „Bogatek”, „Karnawał Pszonki”. Narodowe rocznice były również uświetniane występami sekcji „Orląt”. Zaś sztukę „Było to pod Racławicami” wystawiono na specjalnej scenie, przygotowanej pod gołym niebem, na błoniach krakowskich, w dniu 3 maja 1925 r. Spektakl ten odegrano także w Ojcowie na zamku dnia 14 sierpnia $1927 \mathrm{r}$. w czasie wycieczki wychowanków zakładu, którzy ze względów rodzinnych, zmuszeni byli spędzać wakacje w schronisku ${ }^{256}$. Powyższa lista jest niekompletna, uwzględnia tylko niektóre pozycje bogatego repertuaru sekcji dramatycznej towarzystwa "Orląt".

Obok przedstawień, dużym zainteresowaniem wśród młodych, cieszyły się chóry polifoniczne $\mathrm{i}$ orkiestra, tak nierozłącznie związane $\mathrm{z}$ atmosferą wychowawczą zakładów salezjańskich. Ksiądz Bosko, który na drzwiach sali śpiewu kazał wypisać: „nie przeszkadzaj muzyce”, uważał ją za magncz przyciągający chłopców. Głównie jednak chodziło mu o to, aby przez muzykę i śpiew uwrażliwić wychowanków na piękno i wdrażać im zasady dekalogu. W wychowaniu natomiast uważał muzykę za środek neutralizujący napięcia psychiczne swego radzaju środek terapeutyczny.

Tomasz Czapla, wychowanek salezjańskiej Szkoły Organistowskiej, w Przemyślu, zorganizował w schronisku chór czteroglosowy, co w Krakowie stanowiło rzecz precedensową ${ }^{257}$. Szczególnie dużo czasu i energii pochłaniały próby grup głosowych. Wykorzystywano każdą wolną chwilę, a efekty były widoczne. Dodatkową trudność stwarzał fakt, że chłopcy ci byli uczniami różnych zawodów. Odbywali praktykę w odległych dzielnicach miasta, a co za tym idzie, powrót do zakładu był rozciągnięty w czasie. Postawę pełną zrozumienia i poświęcenia wykazał tu ich kierownik T. Czapla. Szkoda tylko, że dnia 13 września 1927 r. zrezygnował on w pracy w zakładzie. Przeszedł do ojców pijarów na Rakowicach jako nauczyciel śpiewu i kapelmistrz. Jego miejsce zajął, od 24 października 1927 r., kapelmistrz Szajda.

${ }^{255}$ ArITSK, B 1504 Schronisko Lubomirskich. Kronika 1927-1950 (13 III - 10 IV 1927), T. Fundacja Lubomirskiego. Finanse, Sprawozdania roczne, Sprawozdanie dyrektora ks. A. Cieślara do kuratorii z dn. 16 VIII $1926 \mathrm{r}$.

\footnotetext{
${ }^{256}$ ArITSK, B 1504 Schronisko Lubomirskich. Kronika 1927-1950 (14 VIII 1927).

${ }^{257}$ Pocieszajacy objaw, „Echo Bursy”, 1 (1926) nr 2, s. 7-8.
} 
Wspomniany dyrygent chóru Czapla zorganizował także orkiestrę dętą. Początki były trudne. Brakowało instrumentów, a $\mathrm{z}$ posiadanych, większość wymagaly odnowienia (5 kornetów, 2 alty, 3 tenory, 1 bas). Na naprawę ich brakowało funduszów. Z pomocą przyszli: proboszcz ks. K. Tobiasiewicz, który ofiarował na ten cel 25 zł i ks. Lang, były dyrektor schroniska, przekazując $30 \mathrm{zt}^{258}$. Ograniczona ilość instrumentów spowodowała, że kapela liczyła 15 członków. Chłopcy ćwiczyli z takim zaangażowaniem, że przy umiejętnym prowadzeniu przez kapelmistrza wyuczyli się kilku marszów i 24 stycznia 1926 r. mogli dać swój pierwszy występ, grając w czasie przerw komedii „O redaktorze" oraz „Antek kamaszek". Orkiestra uświetniała też uroczystości kościelne, państwowe, wieczorki muzyczne, „dnie i wieczorki misyjne”, a także festyny, urządzane w niedzielne popołudnia przez pomocników salezjańskich, od 1927 r. dwa razy w roku: w maju i wrześniu ${ }^{259}$.

Kapelmistrz T. Czapla zorganizował też orkiestrę smyczkową, która już w grudniu 1926 r. wykonywała partię muzyczną w jasełkach. Obie orkiestry zakładowe uświetniały uroczystości kościelne przy parafii św. Mikołaja ${ }^{260}$. Regularnie od $1928 \mathrm{r}$. podczas procesji rezurekcyjnej i na pasterce w tej parafii grała 40-osobowa orkiestra wychowanków. Składkę w czasie mszy św. rezurekcyjnej zbierał jeden $\mathrm{z}$ przełożonych zakładu, a ofiary proboszcz parafii św. Mikołaja ofiarowywał na potrzeby młodzieży biednej w zakładzie. Było życzeniem dyrekcji, aby zapoczątkowana w 1927 r. praktyka, stała się w następnych latach tradycją. Chętnych do muzykowania było wielu, ale ze względu na brak instrumentów, nie wszyscy mogli być usatysfakcjonowani. Grono wychowanków o zainteresowaniach muzyczno-śpiewaczych w zakładzie stanowiło najliczniejszą grupę Towarzystwa „Orląt”.

W Krakowie w latach dwudziestych został dzięki ks. rektorowi M. Kuznowiczowi ożywiony ruch przeciwalkoholowy. Dnia 6 lutego 1926 r. przybyli do bursy prof. J. Krymski i sekretarz T. Olpiński z centrali kółek abstynenckich w Krakowie z referatem pt. „O zgubnych skutkach alkoholu”. W dniu tym założyli też oni koło abstynenckie w zakładzie. W kwietniu 1926 r. na początku skupiało ono 45 wychowanków. Prezesem koła wybrano niejakiego Windy$\mathrm{sa}^{261}$. Działalność jego obejmowała comiesięczne zebrania, w czasie których głoszono referaty, pogłębiano wiadomości na temat wartości abstynenckiego życia w okresie dojrzewania fizyczno-psychicznego chłopców i oddziaływanie

258 ArITSK, T. Dobrodzieje schroniska Lubomirskich, Lista dobrodziejów w 1925 r.

${ }^{259}$ ArITSK, B 1504 Schronisko Lubomirskich. Kronika 1927-1950 (15 V, 8 IX 1927, 13 V, 12 IX 1928, 9 V, 15 IX 1929, 10 V 1930).

${ }^{260}$ ArITSK, B 1504 Schronisko Lubomirskich. Kronika 1927-1950 (17 IV 1927, 8 IV 1928, 31 III 1929); Z życia mtodzieży w Zaktadzie. Koto amatorskie, „Echo Bursy”, 3 (1928) nr 3-4, s. 4-5.

${ }^{261}$ ArITSK, B 1303 Kronika w schronisku Lubomirskich 1924-1926 (16 II 1926), T. Zakład Lubomirskich. Organizacje młodzieżowe, Protokół z zalożenia koła abstynentów 16 IV 1926 r. 
również na wychowanków dobrym przykładem. Koło organizowało, co roku, w lutym, „tydzień trzeźwości”, służący celom propagandowym. Tydzień taki kończyła okolicznościowa akademia z odpowiednim przedstawieniem scenicznym. Członkowie koła odnawiali na tej akademii przyrzeczenia abstynenckie i uroczyście przyjmowali do swego grona nowych członków ${ }^{262}$.

Z inicjatywy T. Czapli powstało w czasie wakacji 1926 r. Kółko Gimnastyczne „Zdrowie”. „Sportowcy” jak ich nazywano przez codzienne ćwiczenia poranne i specjalne treningi doskonalili swą sprawność fizyczną. Dawali oni popisy gimnastyczne dla publiczności w czasie festynów.

Początki harcerstwa w bursie sięgają 1926 r. Trzeba podkreślić, że właśnie w schronisku powstała pierwsza drużyna harcerska w Krakowie, której członkami byli sami terminatorzy. Organizacja drużyny oraz cel i metody jej działania zostały zapożyczone $\mathrm{z}$ organizacji skautingu, istniejących przy zakładach salezjańskich we Włoszech, Hiszpanii i krajach Ameryki Południowej. Dwóch wychowanków bursy: Józef Lisowski i Władysław Miziołek zajęli się zorganizowaniem drużyny, liczącej 24 członków ${ }^{263}$. Dyrektor ks. Cieślar oddał im dwa skromne pomieszczenia, gdzie gromadzili się na niedzielne zbiórki. Na $1927 \mathrm{r}$. zakreślili sobie bogaty program pracy: zorganizowanie wystawy wyrobów harcerskich, uruchomienie introligatorni, otwarcie sklepiku z przyborami szkolnymi i wystawienie dramatu harcerskiego „Forteca”. Ćwiczenia gimnastyczne i sprawnościowe, rozwijanie osobistych zainteresowań, przygotowywanie sztuk scenicznych, praca nad własnym charakterem - oto całoroczny program drużyny harcerskiej realizowany też w czasie wakacyjnych obozów ${ }^{264}$. Program ten w całości zrealizowano. $\mathbf{Z}$ tego widać, że harcerstwo wyzwalało u młodzieży zapał i energię.

Co roku w miesiącach wakacyjnych harcerze wyjeżdżali na dwutygodniowy obóz. Był on dla nich sprawdzianem sprawności fizycznej, pracowitości, umiejętności organizowania wolnego czasu, szkołą współżycia i współpracy w grupie. Często obozy te odbywały się w atrakcyjnie położonych zakładach salezjańskich lub w ich okolicach. Na obozach obowiązywał harcerski regulamin i stały rozkład dnia. Analiza tego drugiego wykazuje, że preferowano czynny wypoczynek. W Kleczy Dolnej koło Wadowic na obozie drużyny harcerskiej, w dniach 5-18 lipca 1927 r., obowiązywał np. następujący rozkład dnia: ${ }^{265}$ godz. 5.30 - pobudka, gimnastyka, toaleta i uporządkowanie namiotu

${ }^{262}$ ArITSK, B 1303 Kronika w schronisku Lubomirskich 1924-1926 (6 Il 1927).

263 ArITSK, T. Harcerstwo. Kraków Rakowicka 27, Kronika drużyny.

${ }^{264}$ Schronisko w potrzebie, „Echo Bursy”, 1 (1926) nr 7-8, s. 12, Z nowym rokiem, „Echo Bursy", 2 (1927) nr 1-2, s. 5.

265 ArITSK, A 556 Kraków-Rakowicka 27. Schronisko im. ks. A. Lubomirskiego. Harcerstwo, Harcerstwo 1935/1936 - program dnia na obozie, B 1504 Schronisko Lubomirskich. Kronika 1927-1950 (5 VII 1927). 
godz. 7.00

godz. 8.30

godz. 13.00

godz. 18.30

godz. 21.30
- msza św., modlitwy poranne, śniadanie

- ćwiczenia lekkoatletyczne, sprawnościowe, sygnalizacyjne itp.

- obiad, po obiedzie godzina ciszy na prowadzenie zapisków, czytanie lub spoczynek, wycieczki urozmaicone harcerskimi ćwiczeniami sprawnościowymi, kąpiel w rzece

- kolacja, ognisko, spiewy

- modlitwy wieczorne, spoczynek

Harcerstwo, działające w schronisku, w 1927 r. zgłosiło akces do Związku Harcerstwa Polskiego. Przyjęcie to miało miejsce 23 października 1927 r., a dokonal go komendant chorągwi, ks. Marian Lazur ${ }^{266}$.

Związek Harcerstwa Polskiego w latach międzywojennych był organizacją o światopoglądzie katolickim, a jako taki starał się umocnić w swych członkach nie tylko ducha wiary, lecz także wyczulić ich na potrzeby drugiego człowieka. Moment ten był szczególnie akcentowany w drużynie schroniska. Świadczą o tym protokoły wizytacyjne drużyny, pełne uznania dla jej osiągnięć ${ }^{267}$. Jakby na potwierdzenie tego, młodziutką drużynę harcerską spotkało miłe wyróżnienie. Ekspedycja Związku Harcerstwa Polskiego zorganizowała szlak „,dookoła świata". Bawiąc w Krakowie, wybrała schronisko na miejsce swego postoju w dniach 23-29 września 1926 r. Udzieliła przy tej okazji cennych wskazówek instruktorom $^{268}$.

Na koniec należy wspomnieć o hufcu Przysposobienia Wojskowego, zawiązanym w schronisku w roku szkolnym 1928/1929. Należeli do niego wszyscy wychowankowie, którzy ukończyli 16 rok życia. W każdą niedzielę przychodzili do zakładu instruktorzy wojskowi, którzy mieli wykłady teoretyczne do południa, a po południu prowadzili ćwiczenia wojskowe na zakładowym boisku sportowym lub na strzelnicy wojskowej. W związku z tym z konieczności dostosowywano program dnia świątecznego (wysłuchanie dwóch mszy św.) do zajęć hufca. Prawdopodobnie od tego czasu zaniechano odprawianie niedzielnych nieszporów dla wychowanków ${ }^{269}$.

W 1937 r. działało jeszcze Towarzystwo św. Józefa. Spośród jego członków powstał później tzw. mały kler, czyli ministranci. Liturgiczna służba ołtarza,

266 ArITSK, A 556 Kraków-Rakowicka 27. Schronisko im. ks. A. Lubomirskiego. Harcerstwo, Protokół z przystąpienia XII krakowskiej drużyny do Związku Harcerstwa Polskiego 23 X $1927 \mathrm{r}$.

${ }^{267} \mathrm{O}$ prawidłowej i owocnej działalności XII krakowskiej drużyny harcerskiej świadczy protokół powizytacyjny komendanta hufca krakowskiego druha Vilburga i lustratora druha Preisa, którzy w marcu 1929 r. przeprowadzili wizytację drużyny. ArITSK, A 556 Kraków-Rakowicka 27. Schronisko ks. A. Lubomirskiego. Harcerstwo, Protokól powizytacyjny z $1929 \mathrm{r}$.

268 Z życia zakładowego, „Echo Bursy”, 3 (1928) nr 8-10, s. 4.

269 ArITSK, B 1504 Schronisko Lubomirskich. Kronika 1927-1950 (12 XII 1937, 19 III 1938). 
zgromadzona w Towarzystwie Małego Kleru, troszczyła się o zabezpieczenie liturgii.

Trudno $z$ całą pewnością stwierdzić, czy były to już wszystkie formy życia pozalekcyjnego młodzieży w schronisku. Wiadomo, że działało jeszcze Towarzystwo Młodzieży Misyjnej im. Stanisława Kostki, przeznaczone dla uczniów szkoły kupieckiej. Na zebraniu organizacyjnym w kwietniu 1927 r. wybrano prezesem Jarosza ${ }^{270}$. Można wszak przypuszczać, że nie odegrało ono większej roli w życiu zakładu.

\section{Szkoły prowadzone w schronisku}

Salezjanie, po przybyciu na ziemie polskie, byli powszechnie uważani za pionierów szkolnictwa zawodowego. W latach II Rzeczypospolitej prowadzili szkoły zawodowe w Dworcu, Kielcach, Krakowie, Łodzi, Oświęcimiu, Przemyślu, Różanymstoku, Warszawie i w Wilnie ${ }^{271}$. Szkoła krakowska, która powstała w schronisku w 1928 r., wzorowana była na szkole założonej przez księdza Jana Bosko w Turynie. Założyciel salezjanów, przychodząc z pomocą ubogiej młodzieży, przyjmował do swego zakładu maksymalną liczbę wychowanków, nie licząc się z ciężkimi warunkami lokalowymi, czy niedoborem personelu dydaktycznego. Szkoła jego posiadała zatem dużą ilość różnych wydziałów.

Salezjanie polscy niemal kopiowali ten wzór w zakładach otwieranych o wiele lat później. Ich szkoły posiadały zazwyczaj 4 kierunki: mechanicznoślusarski, stolarski, krawiecki i szewski i podobnie jak w czasach ks. Jana Bosko, przeżywały kryzys związany z ciężkimi warunki lokalowymi. Z kwalifikacjami personelu nauczającego także nie było najlepiej. Zwracały na to uwagę władze oświatowe. Z tego powodu wiele szkół, mających kilka wydziałów, musiało je redukować i tworzyć osobne szkoły i gimnazja zawodowe $e^{272}$.

W latach międzywojennych, początkowo nie było jednolitych programów nauczania. Te natomiast, które powstały po 1918 r., opierały się na wzorach austriackich i pruskich. Korzystały z nich także pierwsze szkoły salezjańskie, dołączając własne uwagi ${ }^{273}$. Praktycznie każda prawie szkoła posiadała odrębny program. Władze państwowe chciały ujednolicić system nauczania. W tym celu korzystały z doświadczeń poszczególnych szkół. Normowały więc program i ilość godzin przeznaczonych na zajęcia praktyczne i teoretyczne.

${ }^{270}$ Pamiątka Dnia Mlodzieży, s. 15; Tow. Mlodzieży Misyjnej im. św. Stanistawa Kostki w szkole Kupieckiej, „Echo Bursy”, 2 (1927) or 5-6, s. 2.

${ }^{271}$ Szczer ba, dz. cyt., s. 15-16.

272 Tamże, s. 16.

${ }^{273}$ ArITSK, T. Lubomirscy. Kuratorium Szkolne Krakowskie, Zatwierdzenie komisji egzaminacyjnej przez kuratora szkolnego krakowskiego z dnia 22 XII 1929 r. 
Szkoły w schronisku, podobnie jak inne szkoły salezjańskie, były szkołami prywatnymi lecz z uprawnieniami państwowymi. Posiadały przywilej przeprowadzania egzaminów czeladniczych. Nadzór nad nimi z ramienia państwa sprawował kurator okręgu szkolnego, który na wniosek prowincjała mianował dyrektora szkoły. Ten z kolei kompletował personel dydaktyczny. Szkoły jako prywatne były własnością salezjanów, którzy nimi administrowali przez swoich przedstawicieli, $\mathrm{t} j$. inspektora (prowincjała) wraz ze swoją radą, a także dyrektora miejscowego z kapituła domowa ${ }^{274}$. Uprawnienia inspektora zagwarantowane były w statucie szkoły. Wyznaczał on dyrektora szkoły, personel, spośród członków zgromadzenia, podawał władzom oświatowym normy uposażenia personelu płatnego, powoływał i zmieniał personel administracyjno-gospodarczy placówki (na wniosek dyrektora), otrzymywał od dyrektora okresowe sprawozdania o wynikach nauczania i wychowania ${ }^{275}$.

Dyrektor, jako przełożony domu zakonnego, w którym mieściła się szkoła, był, w imieniu inspektora, jej właściwym administratorem. Zdarzało się, że funkcje dyrektora domu i dyrektora szkoły sprawowała ta sama osoba. Częściej jednak były one rozdzielane. W takim wypadku dyrektor szkoły, chociaż był całkowicie odpowiedzialny za szkołę wobec władz oświatowych, to jednak, jako zakonnik, podlegał dyrektorowi domu i tylko w porozumieniu z nim mógl wypełniać swe obowiązki służbowe $\mathrm{e}^{276}$.

Największą popularnością wśród młodzieży cieszyły się wydziały mechaniczne. Wystarczy wspomnieć, że w 1930 r. na 11 tys. uczniów wszystkich szkól rzemieślniczych w Polsce, około 7 tys. uczęszczało do szkół mechanicznych (metalowych) ${ }^{277}$.

Sprawdzianem zdobycia kwalifikacji zawodowych był egzamin czeladniczy składany przed komisją, której przewodniczącego i członków zatwierdzały władze szkolne. Mógł do niego być dopuszczony uczeń, który otrzymał świadectwo ukończenia szkoły. Egzamin odbywał się w lokalu szkoły w terminie oznaczonym przez kuratora. Kandydat musiał wykazać się opanowaniem wyuczonego przez siebie zawodu w stopniu niezbędnym do wykonywania prac z nim związanych. Miał to potwierdzić egzamin praktyczny. Trwał on trzy dni. Po jego pozytywnym złożeniu, następował egzamin teoretyczny, którego celem było sprawdzenie teoretycznego zasobu wiedzy absolwenta, zarówno z przedmiotów zawodowych, jak i ogólnokształcących ${ }^{278}$.

${ }^{274}$ Ustawy i Regulaminy, art. 110-113, 173, 180, 181 (Ust.).

275 ArITSK, A 636 Schronisko im. Ȧ. Lubomirskiego. Komisja egzaminacyjna, Sprawozdania szkolne 1931/1932 - 1938/1939.

276 Ustawy i Regulaminy, art. 157 (Reg.).

277 Materiaty do organizacji szkolnictwa zawodowego, Lwów 1934, s. 126.

${ }^{278}$ ArITSK, A 636 Schronisko im. A. Lubomirskiego. Komisja egzaminacyjna, Skład komisji egzaminacyjnej w r. 1929 w Szkole Rzemieślniczo-Przemysłowej w Krakowie. 


\section{a) Szkoła szewska}

Prywatna Męska Szkoła Rzemieślniczo-Przemysłowa, istniejąca w schronisku, została zatwierdzona rozporządzeniem Ministra WR i OP 24 października 1928 r. według państwowych programów szkół rzemieślniczych. Posiadała dwa wydziały: szewski i ogrodniczy. Przyjmowani byli do niej chłopcy w wieku 14-16 lat, po ukończonej czteroklasowej szkole ludowej ${ }^{279}$. Nauka trwała trzy lata i obejmowała, obok fachowego wykształcenia rękodzielniczego, także naukę, według programu zatwierdzonego przez ministerstwo. Trzeba zaznaczyć, że szkoły typu szewskiego nie cieszyły się wielką popularnością, na co wskazuje niewielka liczba szkól tego typu i uczniów uczących się tego zawodu. W roku szkolnym 1932/1933 na terenie Polski działało tylko pięć szkół szewskich i trzy cholewkarskie ${ }^{280}$.

Wśród salezjańskich szkół rzemieślniczych dział szewski istniał w Oświęcimiu (1901-1928), Przemyślu (1915-1921) i Kielcach (1919-1928) oraz w Dworcu (1922-1928) i Różanymstoku ${ }^{281}$.

Po reorganizacji szkół zawodowych w 1928 r. dział szewski pozostawiono tylko w dwóch szkołach salezjańskich, w Wilnie i Krakowie. Fragmentaryczne źródła o szkole w Wilnie donoszą, że w roku szkolnym 1930/1931 szewstwa uczyło się tam tylko 18 chłopców. Natomiast informator z 1936 r., wymieniający szkoły salezjańskie, nie wyszczególnia już działu szewskiego przy szkole w Wilnie, co świadczyłoby o jego likwidacji.

Ostatnią i jedyną szkołą salezjańską, przyuczającą do zawodu szewskiego była szkoła w Krakowie. Regulamin warsztatowy był podobny do regulaminu pozostałych szkół salezjańskich w Polsce, uczących tego rzemiosła. Pracownię otwierano o godz. $7.30 \mathrm{i} \mathrm{z} \mathrm{tą} \mathrm{chwilą} \mathrm{rozpoczynał} \mathrm{się} \mathrm{dyżur} \mathrm{w} \mathrm{warsztacie} \mathrm{i} \mathrm{szatni.}$ Przed rozpoczęciem praktyki uczeń był zobowiązany zmienić ubranie na robocze, bez którego zabronione było wejście na halę warsztatową. Zajęcia rozpoczynano modlitwą, po odmówieniu której każdy udawał się na swoje stanowisko pracy. Ponieważ warsztat traktowano jako salę wykładową, dlatego przestrzegano dyscypliny, a wszelkie wykroczenia należały do poważniejszych uchybień. Domagano się od ucznia utrzymania swojego stanowiska pracy w odpowiednim porządku. Potrzebne narzędzia można było otrzymać w wypożyczalni na tzw. marki, a zwrot ich powinien nastąpić w tym samym dniu. Narzędzia zniszczone nie były przyjmowane, wymagano ekwiwalentu na wyrównanie szkody. Ten sam regulamin normował również sprawę opuszczania warsztatów przez ucznia, a także ich stosunek do kierownika i instruktorów.

${ }^{279}$ ArITSK, T. Schronisko Lubomirskich, Prospekt przyjęcia do zakładu.

${ }^{280}$ Szkoly Rzeczypospolitej Polskiej w roku szkolnym 1932/1933, red. M. Falski, Warszawa 1933 , s. 489.

${ }^{281}$ Szczerba, dz. cyt., s. 36. 
Zajęcia warsztatowe odbywały się w godz. $8.00-16.00$, z półtoragodzinną przerwą obiadową ${ }^{282}$.

Dział szewski dysponował dwoma salami warsztatowymi: pracownią cholewkarską i do wyrobu obuwia oraz trzema salami wykładowymi. Zajęcia $\mathrm{z}$ przedmiotów teoretycznych odbywały się $\mathrm{w}$ godzinach wieczornych od godz. 17 do 20. Taki rozkład godzin lekcyjnych nie był odpowiedni dla uczniów. Wizytator, decyzją z 20 kwietnia 1923 r., zalecił, aby zajęcia teoretyczne przenieść na godziny przedpołudniowe ${ }^{283}$.

W pierwszym roku szkolnym 1928/1929 w prywtnej Szkole RzmieślniczoPrzemysłowej w sklad personelu kierowniczego na wydziale szewskim wchodzili:

dyrektor - ks. Józef Liszka

kierownik warsztatów - koad. Feliks Gumula

mistrz szewski - Szynalik instruktor cholewkarski - Jan Bojarski

instruktorzy szewstwa - koad. Antoni Chudzicki, koad. Mikołaj Kościakiewicz, koad. Józef Rudzik

Tab. nr 32: Uczniowie działu szewskiego w latach 1928-1939

\begin{tabular}{|c|c|c|c|c|}
\hline rok & klasa I & klasa II & klasa III & razem \\
\hline $1928 / 1929$ & 12 & 10 & 22 & 44 \\
\hline $1929 / 1930$ & 9 & 15 & 8 & 32 \\
\hline $1930 / 1931$ & 8 & 9 & 4 & 21 \\
\hline $1931 / 1932$ & 7 & 4 & 7 & 18 \\
\hline $1932 / 1933$ & 7 & 4 & 3 & 14 \\
\hline $1933 / 1934$ & 6 & 5 & 4 & 15 \\
\hline $1934 / 1935$ & 6 & 8 & 5 & 19 \\
\hline $1935 / 1936$ & 9 & 7 & 7 & 23 \\
\hline $1936 / 1937$ & 8 & 5 & 6 & 19 \\
\hline $1937 / 1938$ & $\begin{array}{c}\text { nie przyjmo- } \\
\text { wano }\end{array}$ & 5 & 4 & 9 \\
\hline $1938 / 1939$ & - & brak & 6 & 6 \\
\hline
\end{tabular}

Źródło: ArITSK, A 634 Schronisko im. księcia A. Lubomirskiego. Szkola szewska 1926-1939, Sprawozdania z lat szkolnych 1928/1929 - 1938/1939.

282 ArITSK, T. Szkoła szewska. Lubomirskich, Regulamin warsztatów.

${ }^{283}$ ArITSK, A 634 Schronisko im. księcia A. Lubomirskiego. Szkoła szewska 1926-1939, Sprawozdanie $z$ wizytacji 20 IV 1933 r., 12 V 1934 r. 
W pracowni wykonywano obuwie nowe i naprawiano stare. Pierwsza wizytacja szkoły wykazała, że nauczanie zawodu stało na odpowiednim poziomie ${ }^{284}$.

Tab. nr 33: Personel kierowniczy działu szewskiego w Krakowie, w latach 1928-1939

\begin{tabular}{|c|c|c|c|}
\hline r. szk. & dyrektor & kierownik warsztatów & instruktorzy \\
\hline $1928 / 1929$ & ks. J. Liszka & J. Senkara & koad. F. Gumula \\
\hline $1929 / 1930$ & ks. J. Liszka & J. Senkara & $\begin{array}{c}\text { J. Bojarski } \\
\text { koad. A. Chudzicki } \\
\text { koad. F. Gumula } \\
\text { koad. M. Mociakiewicz } \\
\text { koad. J. Rudzik }\end{array}$ \\
\hline $1930 / 1931$ & ks. A. Kazimierczak & koad. F. Gumula & $\begin{array}{c}\text { J. Bojarski } \\
\text { koad. A. Chudzicki } \\
\text { koad. J. Jarząbek } \\
\text { koad. J. Rudzik } \\
\text { koad. B. Wactawek }\end{array}$ \\
\hline $1931 / 1932$ & ks. A. Kazimierczak & koad. f. Gumula & $\begin{array}{c}\text { koad. J. Jarząbek } \\
\text { koad. B. Wacławek }\end{array}$ \\
\hline $1932 / 1933$ & ks. S. Król & koad. F. Gumula & $\begin{array}{c}\text { koad. J. Jarząbek } \\
\text { koad. J. Makucha }\end{array}$ \\
\hline $1933-1938$ & ks. A. Sękowski & koad. F. Gumula & \begin{tabular}{c} 
koad. J. Jarząbek \\
\hline $1938 / 1939$
\end{tabular} \\
\hline
\end{tabular}

Źródło: ArITSK, A 634 Schronisko im. księcia A. Lubomirskiego. Szkoła szewska 1926-1939, Protokół wizytacji 23 III 1929 r., 20 IV 1933 r., 12 V 1934 r., 12 III 1935 r., 16 XII 1935 r., 28 II 1938 r., Sprawozdania z lat szkolnych 1928/1929, 1938/1939; Elenco, 19301939.

Szkoły szewskie w Polsce międzywojennej stopniowo zanikały. Liczba uczniów, zdobywających ten zawód, z każdym rokiem malała. W krakowskiej szkole salezjańskiej było podobnie.

Szkoła, posiadając prawa państwowe, miała przywilej przeprowadzania egzaminów czeladniczych przed własną komisją. Po zakończeniu trzyletniego okresu nauki i otrzymaniu świadectwa ukończenia szkoły, uczeń był dopuszczany do egzaminu czeladniczego. Składało się na niego wykonanie pracy (sztuki czeladniczej) i egzamin z materiału teoretycznego. Na protokole egzaminacyjnym wystawiane były dwie oceny. Dostępne statystyki absolwentów szkoły i dopuszczonych do egzaminu czeladniczego świadczą, że zdawali go wszyscy uczniowie. Analiza protokołów egzaminacyjnych uwidacznia, że większość absolwentów, dopuszczonych do egzaminu, zdawała go bez większych

${ }^{284}$ ArITSK, A 634 Schronisko im. księcia A. Lubomirskiego. Szkoła szewska 1926-1939, Uwagi z wizytacji warsztatów szewskich 23 III 1929 r. 
trudności. W wypadku niepomyślnego wyniku egzaminu można go było powtórzyć. W roku szkolnym 1928/1929 dyplomy czeladnicze w krakowskiej Salezjańskiej Szkole Rzemiosł (tak była popularnie nazywana) otrzymała największa liczba absolwentów - 18. Najmniej zadwało w roku szkolnym 1932/1933 - tylko $3^{285}$.

Skład komisji egzaminacyjnej dyrekcja szkoły przedstawiała Kuratorium do 25 maja każdego roku. Ostateczny jej skład ustalany był w porozumieniu między Kuratorium a Izbą Rzemieślniczą, która na egzamin kierowała swego przedstawiciela.

Tab. nr 34: Komisja egzaminacyjna na czeladników działu szewskiego Prywatnej Męskiej Szkoły Rzemieślniczo-Przemysłowej w Krakowie, w latach 1929-1939

\begin{tabular}{|c|c|c|c|}
\hline data & przewodniczący & $\begin{array}{c}\text { przedstawiciel } \\
\text { Izby Rzemieślniczej }\end{array}$ & członkowie \\
\hline 15 VI 1929 & Stanisław Tasiecki & Kazimierz Gałuszkiewicz & $\begin{array}{c}\text { Jan Senkara } \\
\text { Antoni Trojan }\end{array}$ \\
\hline 6 VI 1930 & ks. Tadeusz Głąb & Kazimierz Gałuszkiewicz & $\begin{array}{c}\text { koad. Feliks Gumula } \\
\text { Jan Senkara }\end{array}$ \\
\hline 24 VI 1931 & $\begin{array}{c}\text { ks. Antoni } \\
\text { Kazimierczak }\end{array}$ & Kazimierz Gałuszkiewicz & $\begin{array}{c}\text { Michał Gronuś } \\
\text { Stanisław Tasiecki }\end{array}$ \\
\hline 23-25 VI 1932 & $\begin{array}{c}\text { ks. Antoni } \\
\text { Kazimierczak }\end{array}$ & Kazimierz Gałuszkiewicz & $\begin{array}{c}\text { Alfred Słowik } \\
\text { Stanisław Tasiecki }\end{array}$ \\
\hline 1933 & $\begin{array}{c}\text { ks. Sylwester Król } \\
\text { kl. Ignacy Baran } \\
\text { koad. Feliks Gumula }\end{array}$ \\
\hline $11-12$ VI 1934 & ks. Alojzy Sękowski & Kazimierz Gałuszkiewicz & koad. Feliks Gumula \\
\hline 10-12 VI 1935 & ks. Alojzy Sękowski & Kazimierz Gałuszkiewicz & koad. Feliks Gumula \\
\hline 8-10 VI 1936 & ks. Alojzy Sękowski & Kazimierz Gałuszkiewicz & koad. Feliks Gumula \\
\hline 9 VI 1937 & ks. Alojzy Sękowski & Kazimierz Gałuszkiewicz & koad. Feliks Gumula \\
\hline 15 VI 1938 & ks. Alojzy Sękowski & Kazimierz Gałuszkiewicz & koad. Feliks Gumula \\
\hline 14 VI 1939 & ks. Alojzy Sękowski & Kazimierz Gałuszkiewicz & koad. Feliks Gumula \\
\hline
\end{tabular}

Źródło: ArITSK, A 636 Schronisko im. A. Lubomirskiego. Komisja egzaminacyjna, Protokoły egzaminu czeladniczego szewskiego 1929-1939, Szkoła szewska - sprawozdania z egzaminów na czeladników 1929-1939, Szkoła szewska - komisje egzaminu czeladniczego 19291939.

285 ArITSK, A 634 Schronisko im. księcia A. Lubomirskiego. Szkoła szewska 1926-1939, Skład komisji egzaminacyjnej w 1929 r., Zatwierdzenie komisji egzaminacyjnej z 22 XI 1929 r., Komisja egzaminacyjna czeladników 1929-1939, A 636 Schronisko im. A. Lubomirskiego. Komisja egzaminacyjna, Wykaz szkół rzemieślniczo-przemysłowych okręgu krakowskiego, przy których w roku szkolnym 1928/1929 mogą być tworzone komisje dla egzaminów na czeladników - załącznik do okólnika Kuratorium krakowskiego L. III 1855/29. 
Wobec ciągłego spadku ilości zgłoszeń kandydatów do działu szewskiego dyrekcja, w roku szkolnym 1933/1934, zaniechała nauki przedmiotów teoretycznych w zakładzie. Pobierali ją uczniowie w Publicznej Szkole Dokształcającej w Krakowie przy ul. Sarego $27^{286}$. Natomiast zajęcia warsztatowe od tego roku poszerzono o lekcje: rysunków zawodowych, technologię, organizację pracy i kalkulację. Odbywały się one w pracowni na miejscu w piątki i soboty.

W Polsce międzywojennej egzystowały tylko te szkoły prywatne, które dysponowały odpowiednimi środkami materialnymi na swoje utrzymanie i kiedy w danym środowisku lub terenie występowało zapotrzebowanie na tego rodzaju szkoły. Los salezjańskiej szkoły szewskiej w Krakowie obrazuje z pewnością stan szkolnictwa zawodowego szewskiego w szerszej skali. Karol Rudolphi, w sprawozdaniu powizytacyjnym z 1934 r. napisał: „Rzemiosło szewskie upada, czego dowodem malejąca corocznie liczba uczniów nie tylko w szkołach zawodowych dziennych, ale i w szkołach dokształacjących. $\mathrm{Na}$ terenie okręgu krakowskiego są tylko dwie szkoły szewskie: salezjańska w Krakowie i oddział szewski Szkoły Rzemieślniczo-Przemysłowej w Zawichoście"287. Dział szewski w Krakowie również nie zdołał się utrzymać z powodu małego zainteresowania tym zawodem. Dyrekcja postanowiła go zlikwidować. Decyzję taką podjęto na posiedzeniu kapituły domowej 19 marca 1937 r. Wkrótce wysłano zawiadomienie do władz szkolnych i Izby Rzemieślniczej o nieprzyjmowaniu kandydatów do klasy pierwszej. Na to miejsce planowano przyjąć większą liczbę uczniów szkoły powszechnej. Na posiedzeniu kuratorii 12 marca 1939 r. rozważana była możliwość, aby w miejsce likwidowanych stopniowo klas szewskiego oddziału, otworzyć dział krawiecki. Zanim zdołano to zrealizować, wybuchła wojna ${ }^{288}$.

Kuratorium Okręgu Szkolnego w Krakowie, 21 sierpnia 1937 r. wyraziło zgodę na nieorganizowanie naboru do klas I od roku szkolnego 1937/1938. Uczniowie klasy II i III kontynuowali naukę w szkole dokształcającej przy ul. Sarego 27. Praktykę zdobywali na miejscu. Dnia 31 sierpnia 1939 r. dyrekcja Prywatnej Męskiej Szkoły Rzemieślniczo-Przemysłowej Towarzystwa Salezjańskiego w Krakowie zamknęła dział szewski ${ }^{289}$.

${ }^{286}$ ArITSK, A 634 Schronisko im. księcia A. Lubomirskiego. Szkoła szewska 1926-1939, Dyrcktor Sękowski do Kuratorium 22 IX, 25 X 1933 r., Projekt zmian i ulepszeń w nowym roku szkolnym 1933/1934 w zakresie nauczania, Sprawozdanie z wizytacji 12 V 1934 r.

${ }^{287}$ Trzeba dodać, że ta druga została w 1936 r. zlikwidowana. ArITSK, A 634 Schronisko im. księcia A. Lubomirskiego. Szkoła szewska 1926-1939, Sprawozdanie wizytacyjne z 12 V 1934 r.; Szkoty Rzeczypospolitej Polskiej w roku szkolnym 1930/31, s. 483-486.

${ }^{288}$ ArITSK, B 1504 Schronisko Lubomirskich. Kronika 1927-1950 (19 III 1937, 12 III 1939).

289 ArITSK, A 634 Schronisko im. księcia A. Lubomirskiego. Szkoła szewska 1926-1939, Kuratorium do dyrekcji 21 VIII 1937 r., Dyrektor Sękowski do Kuratorium 25 X 1938 r., 21 VIII $1939 \mathrm{r}$. 
Szkoły szewskie w ciągu 3 lat trwania nauki poświęcały około 3 tys. godzin na nauczanie zawodu, a na przedmioty teoretyczne przeznaczały około 1 tys. godzin. Po przeliczeniu uczeń szkoły szewskiej w ciągu dnia miał 7-8 godzin zajęć szkolnych ${ }^{290}$.

Mówiąc o liczebności uczniów w szkole szewskiej, należy wspomnieć o absolwentach z dyplomem czeladniczym. W szkole tej w latach 1928-1938 dyplom czeladnika otrzymało 78 absolwentów ${ }^{291}$.

Tab. nr 35: Czeladnicy działu szewskiego Prywatnej Męskiej Szkoły RzemieślniczoPrzemysłowej w latach 1929- 1939

\begin{tabular}{|c|c|c|}
\hline r. szk. & uczniowie kl. III & wyzwoleni czeladnicy \\
\hline $1928 / 1929$ & 18 & $\begin{array}{c}23 \text { (2 z Oświęcimia, } \\
\text { 3 z Zawichostu) }\end{array}$ \\
\hline $1929 / 1930$ & 14 & 14 \\
\hline $1930 / 1931$ & 7 & 7 \\
\hline $1931 / 1932$ & 6 & 6 \\
\hline $1932 / 1933$ & 3 & 3 \\
\hline $1933 / 1934$ & 4 & 4 \\
\hline $1934 / 1935$ & 4 & 4 \\
\hline $1935 / 1936$ & 5 & 5 \\
\hline $1936 / 1937$ & 5 & 5 \\
\hline $1937 / 1938$ & 6 & 6 \\
\hline $1938 / 1939$ & 8 & 8 \\
\hline
\end{tabular}

Źródło: ArITSK, A 634 Schronisko im. księcia A. Lubomirskiego. Szkoła szewska 1926-1939, Dyrektor Sękowski do Kuratorium: Spis absolwentów szkoły szewskiej w roku 1929, 1931-1939.

Tab. nr 36: Nauczyciele działu szewskiego Szkoły Rzmieślniczo-Przemysłowej w Krakowie

\begin{tabular}{|l|c|c|}
\hline \multicolumn{1}{|c|}{ imię i nazwisko } & lata pracy & przedmiot wykładany \\
\hline koad. Ignacy Baran & $1932 / 1933$ & $\begin{array}{c}\text { korespondencja, księgowość, matematyka, } \\
\text { rysunki }\end{array}$ \\
\hline kl. Antoni Bursiewicz & $1931 / 1932$ & język polski \\
\hline ks. Jan Domino & $1930 / 1931$ & fizyka \\
\hline Kazimierz Gałuszkiewicz & $1931-1933$ & kalkulacja, materiałoznawstwo \\
\hline
\end{tabular}

${ }^{290}$ Materiaty do organizacji szkolnictwa, s. 136-138.

${ }^{291}$ ArITSK, T. Szkoła szewska. Lubomirskich, Katalog główny 1928-1939, absolwenci. 


\begin{tabular}{|c|c|c|}
\hline koad. Feliks Gumula & $1930-1939$ & organizacja pracy, rysunek zawodowy \\
\hline koad. Jan Jarząbek & $1931-1938$ & technologia, teoria szewstwa \\
\hline ks. Antoni Kazimierczak & $1930-1932$ & religia \\
\hline ks. Sylwester Król & $1932-1936$ & religia \\
\hline ks. Józef Liszka & $1928-1930$ & religia \\
\hline Kazimierz Patuszkiewicz & $1931 / 1932$ & kalkulacja, materiałoznawstwo \\
\hline ks. Alojzy Sękowski & $1933-1939$ & nauka obywatelstwa, obrona przeciwlotnicza \\
\hline Alfred Słowik ${ }^{292}$ & $1931 / 1932$ & \\
\hline kl. Leon Wach & $1931 / 1932$ & \\
\hline dr Wilk Julian & $1928 / 1929$ & higiena \\
\hline kl. Hipolit Włodarz & $1931 / 1932$ & \\
\hline kl. Stefan Wojciechowski & $1931 / 1932$ & język polski, fizyka \\
\hline
\end{tabular}

Źródło: ArITSK, A 634 Schronisko im. księcia A. Lubomirskiego. Szkoła szewska 1926-1939, Protokoły wizytacji z lat 1929, 1933-1935, Sprawozdania dyrektora za lata 1932/1933 1938/1939, Wykazy osobiste nauczycieli niepaństwowych szkól zawodowych 1930-1939, A 636 Schronisko im. A. Lubomirskiego. Komisja egzaminacyjna, Dyrekcja do Kuratorium 6 V 1928 r., 30 V 1931 r., 3 VI 1932 r., 15 V 1933 r., 20 IV 1934 r., Kuratorium do dyrekcji 15 VI 1929 r., 9 V, 6 VI 1930 r., 18 VI 1931 r., 18 V 1933 r.

Jedyna w krakowskim okręgu szkolnym salezjańska szkoła szewska w Krakowie również nie zdołała utrzymać swej żywotności, jednak nie z winy personelu, lecz małego zainteresowania społeczeństwa zawodem szewskim. Władze szkolne, mając nadzieję utrzymania tej specjalności, okazały salezjanom pełne zaufanie, a nawet gotowość przyjścia z pomocą w otwarciu nowej szkoły tego typu. Pomimo zachęt ze strony władz szkolnych, nie zdołano jej utrzymać $^{293}$.

\section{b) Szkoła ogrodnicza}

W 1932 r. funkcjonowały w Polsce trzy szkoły ogrodnicze, które kształciły łącznie 180 uczniów. Główny nacisk kładziono w nich na praktyczne wyszkolenie ogrodników. Początkowo podlegały one Ministerstwu Rolnictwa i Reform Rolnych, a od 1932 r. przeszły pod Ministerstwo Wyznań Religijnych i Oświecenia Publicznego. Szkoły ogrodnicze były trzyletnie. Zakładano, że ogrodnik opuszczający szkołę będzie mógł pracować we wszystkich dziedzi-

292 Wykladał w szkole spolecznie. ArITSK, B 1504 Schronisko Lubomirskich. Kronika 19271950 (22 IX 1931).

293 ArITSK, A 634 Schronisko im. księcia A. Lubomirskiego. Szkola szewska 1926-1939, Sękowski do Kuratorium Okręgu Szkolnego Krakowskiego 21 VIII 1939 r. 
nach ogrodnictwa, dlatego w nauczaniu nie stosowano specjalizacji. Można ją było osiągnąć dopiero po ukończeniu szkoły ${ }^{294}$.

W salezjańskich szkołach w Polsce ogrodnictwu nie okazywano szczególnego zainteresowania. Początkowo traktowano je jako zajęcia nadobowiązkowe dla uczniów innych kierunków ${ }^{295}$. Od $1928 \mathrm{r}$. dział ogrodniczy istniał w Prywatnej Męskiej Szkole Rzmieślniczo-Przemysłowej w schornisku fundacji A. Lubomirskiego. I tutaj dopiero ogrodnictwo doczekało się usamodzielnienia. Po trzech latach funkcjonowania działu ogrodniczego w Szkole Rzmieślniczo-Przemysłowej, za dyrektorstwa ks. Antoniego Kazimierczaka, dział ogrodniczy usamodzielnił się. Dnia 1 października $1931 \mathrm{r}$. otwarto tu Publiczną Szkolę Dokształcającą Zawodową nr 24 dla ogrodników ${ }^{296}$.

Podstawą do jej otwarcia był prawie siedmiohektarowy ogród z dwoma cieplarniami i inspektami, nadający się doskonale do praktyki ogrodniczej. Kierownikiem szkoły został dr Karol Starmach. Faktycznie jednak szkołą kierował prefekt zakładu i kierownik kursów ogrodniczych ks. A. Sękowski, twórca i organizator działu ogrodniczego i późniejszy dyrektor zakładu i szkoły w latach 1933-1939. Doświadczenie w tej dziedzinie zdobył w rzymskiej szkole rolniczej w Mandrione, a studia w tym zakresie kontynuował na Uniwersytecie Jagiellońskim. Znany był również jako wybitny znawca pszczelarstwa ${ }^{297}$.

Podstawowym warunkiem przyjęcia do szkoły ogrodniczej była wyraźnie określona granica wieku, regulowana przepisami ministerstwa. W przeciwieństwie do pozostałych szkół zawodowych, dla szkół ogrodniczych Ministerstwo zawyżyło wiek kandydatów ze względu na ciężką pracę, określając go na 1624 lat $^{298}$.

Przedmioty nauczania podzielono na trzy grupy. Pierwszą z nich stanowiły przedmioty zawodowe: zajęcia praktyczne, gleboznawstwo, uprawa i nawożenie roli, warzywnictwo. Następną grupę z kolei stanowiły nauki pomocnicze, związane $\mathrm{z}$ zawodem: botanika, hodowla i żywienie zwierząt. Wreszcie do trzeciej grupy należały te przedmioty, które nie były bezpośrednio związane z zawodem: religia, język polski, historia i wychowanie fizyczne.

W szkole ogrodniczej przewidziane były dwa semestry: letni (kwiecień, maj, czerwiec, wrzesień, październik) i zimowy (listopad, grudzień, styczeń, luty, marzec) uwzględnione przy podziale zajęć. Ponieważ szkoła była półsezonowa, ze względu na zajęcia praktyczne w ogrodzie, nauka przedmiotów teore-

${ }^{294}$ Materialy do organizacji szkolnictwa, s. 1008-1009.

${ }^{295}$ Tak było, np. w szkole organistowskiej w Przemyślu.

296 ArITSK, A 602 Schronisko im. Lubomirskiego. Szkoła ogrodnicza, Kuratorium szkolne do dyrekcji schroniska 23 IX $1931 \mathrm{r}$.

297 ArITSK, T. Nekrologi, Ks. Alojzy Sękowski; Śl ó s a r c zy k, dz. cyt., t. 2, s. 255-256.

${ }^{298}$ ArITSK, A 604 Schronisko im. Lubomirskiego. Szkoła ogrodnicza, Prospekt przyjęcia do zakładu. 
tycznych odbywała się przez cztery dni tygodnia: od poniedziałku do piątku. W okresie letnim wymiar zajęć lekcyjnych wynosił dwie godziny dziennie: od godz. 18.00-20.00. W semestrze zimowym cztery godziny dziennie: od godz. 16.00-20.00. Zajęcia hufca szkolnego dla wszystkich uczniów, któnzy ukończyli 16 lat odbywały się w piątki od godz. 17 do 19 przez cały rok szkolny. Zdobywano na nim sprawności i odznaki sportowe oraz strzeleckie. Również w piątki, po zajęciach hufca szkolnego, odbywały się cotygodniowe zebrania koła ogrodników. Miały one charakter dokształcający (referaty, czasopisma fachowe) i towarzyski. Rozporządzało własnym funduszem złożonym z niewielkich składek członkowskich. Dzieliło się na dwie sekcje: kwiaciarską i warzywniczą. Nierzadko z referatami zapraszano gości z miasta. Na każdym zebraniu poka-zywano ciekawsze okazy roślin doniczkowych i objaśniano ich hodowlę ${ }^{299}$.

Koszty utrzymania szkoły ponosiły władze państwowe (2/3) i gmina miasta Krakowa (1/3). Lokal, światło, opał i obsługę otrzymywała szkoła bezpłatnie ze schroniska. Wydatki na pomoce naukowe, przybory kancelaryjne, szkolne, wycieczki itp. pokrywane były wyłącznie $z$ opłat uczniów. Jednorazowe wpisowe w wysokości od 1 do 4 zł, w zależności od zamożności rodziców ucznia, ściągane było najczęściej w późniejszych miesiącach, nawet w dogodnych ratach ${ }^{300}$.

Naukę w szkole ogrodniczej pobierało rocznie około 90 uczniów.

Tab. nr 37: Uczniowie Publicznej Szkoły Dokształcającej Zawodowej nr 24 dla ogrodników w latach 1931-1939

\begin{tabular}{|c|c|c|c|c|}
\hline rok & klasa I & klasa II & klasa III & razem \\
\hline $1931 / 1932$ & 22 & 40 & 32 & 94 \\
\hline $1932 / 1933$ & 21 & 27 & 25 & 73 \\
\hline $1933 / 1934$ & 37 & 30 & 21 & 88 \\
\hline $1934 / 1935$ & 29 & 36 & 21 & 86 \\
\hline $1935 / 1936$ & 34 & 27 & 23 & 84 \\
\hline $1936 / 1937$ & 44 & 28 & 21 & 93 \\
\hline $1937 / 1938$ & 37 & 32 & 22 & 91 \\
\hline $1938 / 1939$ & 37 & 25 & 23 & 85 \\
\hline
\end{tabular}

Źródło: ArITSK, A: 586, 586a, 586b, 587b, 588, 588a, 588b, 589, 589a, 589b Lubomirscy. Szkoła dla ogrodników, Dzienniki szkolne 1931-1939.

${ }^{299}$ ArITSK, A 606 Schronisko im. A. Lubomirskiego. Program Publicznej Szkoły Dokształcającej Zawodowej nr 24 dla ogrodników w Krakowie, Rozkład materiału 1934/1935, Wykaz lekcji w latach 1931-1939, Program szkoły półsezonowej dla ogrodników 1931-1939; S z c z e r b a, dz. cyt., s. 40 .

${ }^{300}$ ArITSK, A 606 Schronisko im. A. Lubomirskiego. Program Publicznej Szkoły Dokształcającej Zawodowej nr 24 dla ogrodników w Krakowie, Sprawozdanie roczne 1933/1934 do Kuratorium szkolnego. 
Tab. nr 38: Liczba absolwentów i czeladników Publicznej Szkoły Dokształcającej Zawodowej nr 24 dla ogrodników, w latach 1929-1937

\begin{tabular}{|c|c|c|}
\hline rok & absolwenci & czeladnicy \\
\hline $1929 / 1930$ & 3 & - \\
\hline $1930 / 1931$ & 5 & - \\
\hline $1931 / 1932$ & 7 & 16 \\
\hline $1932 / 1933$ & 11 & $?$ \\
\hline $1933 / 1934$ & 17 & 16 \\
\hline $1934 / 1935$ & 17 & 17 \\
\hline $1935 / 1936$ & 23 & 21 \\
\hline $1936 / 1937$ & $?$ & 17 \\
\hline $1937 / 1938$ & $?$ & $?$ \\
\hline
\end{tabular}

Źródlo: ArlTSK, A 607 Schronisko im. A. Lubomirskiego. Szkoła ogrodnicza, Spis uczniów szkoły ogrodniczej 1931-1938, Lista absolwentów 1929-1936.

Zakłady naukowe Krakowa i okolicy urządzały wycieczki naukowe do salezjańskiej szkoły ogrodniczej dla zapoznania się z pszczelarstwem u ks. Sękowskiego. Przychodzili również praktykanci z ogrodów miejskich i prywatnych.

Tab. nr 39: Nauczyciele Publicznej Szkoły Dokształcającej Zawodowej nr 24 dla ogrodników w Krakowie

\begin{tabular}{|l|c|c|}
\hline \multicolumn{1}{|c|}{ nazwisko i imię } & lata pracy & przedmioty wykładane \\
\hline Gawrzyński Stanisław & $1931-1935$ & $\begin{array}{c}\text { planowanie ogrodnictwa, rysunek zawodowy } \\
\text { i geometryczny }\end{array}$ \\
\hline dr Goc Franciszek & $\begin{array}{c}1933-31 \text { XII } \\
1936\end{array}$ & przetwórstwo, sadownictwo \\
\hline Grzegorczyk Zygmunt & $1932-1939$ & $\begin{array}{c}\text { buchalteria i kalkulacja, ogrodnictwo, } \\
\text { przetwórstwo, rachunkowść }\end{array}$ \\
\hline mgr Jemioła Józef & $1937-1939$ & warzywnictwo \\
\hline ks. Kazimierczak Antoni & $1930-1932$ & religia \\
\hline Kwaśnicka Julia & $1933-1938$ & $\begin{array}{c}\text { ćwiczenia z warzywnictwa, gleboznawstwo, } \\
\text { kwiaciarstwo, warzywnictwo }\end{array}$ \\
\hline inż. Michalski Wacław & 1 I 1937-1939 & sadownictwo \\
\hline Murczyńska Julia & $1933-1936$ & $\begin{array}{c}\text { nauka obywatelska, } \\
\text { wiadomości z życia roślin i zwierząt }\end{array}$ \\
\hline Pawłowski Edward & $1931-1939$ & $\begin{array}{c}\text { język polski, geografia, krajoznawstwo, } \\
\text { rachunki, hufiec szkolny od 1 I 1935 r. }\end{array}$ \\
\hline
\end{tabular}




\begin{tabular}{|c|c|c|}
\hline Prokopowicz Zygmunt & $\begin{array}{c}1931-31 \text { XII } \\
1934\end{array}$ & $\begin{array}{l}\text { gleboznawstwo, sadownictwo, uprawa roli, } \\
\text { technika zawodowa i ćwiczenia }\end{array}$ \\
\hline ks. Sękowski Alojzy & $1932-1939$ & $\begin{array}{l}\text { miernictwo i niwelacja, nauka obywatelska, } \\
\text { pszczelarstwo, religia }\end{array}$ \\
\hline Sieczkówna Irena & $1932-1936$ & język polski, korespondencja \\
\hline Szulewski Bronisław & 1 I 1936-1939 & planowanie ogrodów \\
\hline dr Starmach Karol & $1931-1939$ & $\begin{array}{l}\text { wiadomości z przyrody, } \\
\text { wiadomości z życia roślin }\end{array}$ \\
\hline ks. Szembek Włodzimierz & $1938 / 1939$ & uprawa roślin, warzywnictwo \\
\hline Witkowski Antoni & $\begin{array}{l}1932 / 1933 \\
1937-1939\end{array}$ & kwiaciarstwo, warzywnictwo \\
\hline Wróblewska Helena & 1 I I 1935-1936 & planowanie ogrodów, rysunek zawodowy \\
\hline
\end{tabular}

Źródło: ArITSK, A 606 Schronisko im. A. Lubomirskiego. Program Publicznej Szkoły Dokształcającej Zawodowej nr 24 dla ogrodników w Krakowie, Wykaz zajęć grona nauczycielskiego 1931-1938, B 1504 Schronisko Lubomirskich. Kronika 1927-1950 (8 X 1932 - 15 VI 1939).

Szkoła miała dobre wyniki i odpowiedni poziom naukowy. Biorąc to pod uwagę, na prośbę dyrekcji szkoły Ministerstwo WRiOP podniosło jej rangę do kategorii dzisiejszego technikum. Przyjęła ona nazwę „Prywatnej Męskiej Szkoły Ogrodniczej Towarzystwa Salezjańskiego w Krakowie"301. Niestety, fakt ten miał miejsce dopiero 27 maja 1939 r., tak że w nowej roli szkoła nie prowadziła nigdy zajęć.

W uznaniu zasług dla ks. Sękowskiego, organizatora szkoły ogrodniczej i jej dyrektora oraz pracy na tym odcinku (praca badawcza w zakresie prszczelarstwa - hodowla matek), dnia 28 października 1936 r. ks. Sękowski został odznaczony i udekorowany przez władze miasta Złotym Krzyżem Zasługi za pracę społeczną. Przeszło pół roku później, 27 maja 1937 r., otrzymał od władz Uniwersytetu Jagiellońskiego propozycję objęcia katedry i prowadzenia wykładów z zakresu pszczelarstwa. Wojna przekreśliła wszystkie plany, zarówno działalności zakładu, szkoły jak i pracy ks. Sękowskiego na uczelni krakowskiej ${ }^{302}$.

Ważną sprawą dla szkoły jest zawsze biblioteka. W szkole zawodowej powinna ona posiadać $w$ swoim księgozbiorze przede wszystkim pozycje zawodowe, zarówno dla nauczycieli, jak i uczniów. Sprawą doboru książek inte-

${ }^{301}$ ArITSK, A 647 Schronisko Lubomirskiego. Kuratorium 1939, Kuratorium do dyrekcji szkoły 27 maja 1939 r.; S w i d a, Salezjańskie szkolnictwo, s. 46.

${ }^{302}$ Po II wojnie światowej ks. Sękowski był w 1946 r. prezesem Wojewódzkiego Związku Pszczelarzy. ArITSK, A 563 Kraków-Rakowicka 27. Schronisko in. ks. Lubomirskiego. Wizytacje inspektorialne 1934-1938 1945-1947, Sprawozdanie z wizytacji ks. Cieślara z 28 XI 1938 r., 5 I 1946 r., B 1504 Schronisko Lubomirskich. Kronika 1927-1950 (28 X 1938, 27 V 1939). 
resowało się ministerstwo, podając ich spisy, polecanych dla czytelń szkolnych. Kryteria doboru książek do bibliotek szkolnych w zakładach salezjańskich ustalały jednak przepisy zgromadzenia, które wykluczaly pewne pozycje ${ }^{303}$. W szkole rzemieślniczej w Krakowie istniała biblioteka, licząca 662 tomy, $z$ czego 462 to beletrystyka, 142 pozycje naukowe dla nauczycieli, 32 naukowe dla młodzieży i 26 podręczników szkolnych ${ }^{304}$.

Nie wystarczające było zaopatrzenie biblioteki w literaturę zawodową, przygotowującą uczniów w dziedzinie ogrodnictwa. W czasie wizytacji inspektorialnej, przeprowadzanej corocznie, ks. Cieślar zwrócił na to uwagę w sprawozdaniu, pozostawiając zalecenie, by zaopatrzyć bibliotekę w odpowiednią ilość książek i pism fachowych, ale również zachęcać uczniów do pilnej ich lektury ${ }^{305}$.

\section{Oratorium salezjańskie}

Klasycznym rodzajem pracy wychowawczej, szczególnie uprzywilejowanej w zgromadzeniu salezjańskim, a posiadającej priorytetowe znaczenie w działalności wychowawczej ks. Bosko było tzw. oratorium ${ }^{306}$. W niedziele i święta, a potem częściej, zwłaszcza w czasie Wielkiego Postu, ks. Bosko zbierał chłopców w dogodnym miejscu nawet pod gołym niebem stwarzając im sposobność do wspólnych gier i zabaw, które przeplatał pogadankami religijnymi, zwykle potem, po odpowiedniej porcji relaksu, ksiądz Bosko zabierał wychowanków na nabożeństwo do kościoła. Tę formę oddziaływania wychowawczego określał lapidarnym stwierdzeniem: „róbcie, co chcecie, bylebyście tylko nie grzeszyli”307. Z biegiem czasu wybudował też przy swoim domu w Turynie małą kaplicę, czyli oratorium, dom modlitwy. Była ona wzorem dla setek późniejszych oratoriów salezjańskich. Oratorium było początkowo jedyną formą działalności ks. Bosko, które miało na celu gromadzenie opuszczonej młodzieży pozaszkolnej, lub uczącej się w godzinach pozalekcyjnych. Ksiądz Bosko chciał zgromadzić w oratorium jak największą liczbę młodzieży męskiej, by móc oddziaływać na nią dodatnio, a przez nią wywierać wpływ także na środowisko, z którego pochodziła.

${ }^{303}$ Ustawy i Regulaminy, art. 42, 119 (Reg.).

${ }^{304}$ ArITSK, T. Schronisko Lubomirskich, Inwentarz biblioteki szkolnej w schronisku.

${ }^{305}$ Zwrócił uwagę, że większą korzyść przyniosłyby młodzieży wykłady i pogadanki ilustrowane przeźroczami z dziedziny przyrody (np. szkodniki i pasożyty roślin i zwierząt, sprzymierzeńcy w ochronie przyrody), urządzane ponadplanowo w piątki, soboty i niedziele. ArITSK, A 563 Kraków-Rakowicka 27. Schronisko in. ks. Lubomirskiego. Wizytacje inspektorialne 1934-11938 1945-1947, Sprawozdanie z wizytacji ks. Cieślara w dniach 24-28 XI 1938 r.

306 Sw. Jan Bosko, Kraków 1938, s. 13-14.

${ }^{307}$ Ustawy i Regulaminy, art. 87-104 (Reg.). 
Oratorium, jakie proponował ks. Bosko, to nie zakład czy lokal z pewną narzuconą wcześniej dyscypliną, udostępniony pewnej tylko grupie chłopców, $\mathrm{z}$ wykluczeniem innych. Zgodnie $\mathrm{z}$ jego zamierzeniem, wstęp do oratorium mieli wszyscy chłopcy powyżej 7 lat, bez różnicy pochodzenia czy stopnia zamożności. Jedynym warunkiem była chęć pożytecznego spędzenia cza$\mathrm{su}^{308}$. Ta forma działalności rozwijała się pomyślnie. W krótkim stosunkowo czasie, gdy liczba oratorianów dochodziła do kilkuset, okazało się, że dla wielu z nich niezbędny jest stały punkt oparcia. Ksiądz Bosko dla tych, którzy chcieli się uczyć otworzył szkoły zawodowe i licealne, bursy i internaty. Oratoryjna działalność ks. Bosko zdominowała inne formy jego apostolstwa, stąd jego pierwszy dom w Turynie przyjął nazwę „Oratorium”. Później salezjanie, kładąc wprawdzie nacisk na elitarność oddziaływania pedagogicznego (domy zamknięte), tworzyli jednak przy tych zakładach oratoria, przez które prowadzili zewnętrzne, ekspansywne akcje duszpasterskie. Działalność ta zdobyła powszechne uznanie i aplauz wśród pedagogów.

Analizując dzisiejszą działalność świetlicową, czy klubową z młodzieżą, dochodzi się do wniosku, że została ona stworzona na wzór oratoriów ks. Bosko, z tą różnica, iż zmieniono główny cel wychowawczy, tj. cel religijny zastąpiono świeckim (a środki pozostawiono prawie te same).

Swą działalność w Polsce salezjanie rozpoczęli w Oświęcimiu w $1898 \mathrm{r}$. założeniem internatu, połączonego później z gimnazjum i szkołą zawodową. Początkowo nie okazywali oni szczególnego zainteresowania młodzieżą spoza zakładu $^{309}$, chociaż trzeba zaznaczyć, że od pierwszych tygodni po ich przybyciu przychodziła do zakładu grupa chłopców z miasta. Byli to pierwsi oratorianie, którzy stanowili grono późniejszych terminatorów. Pierwsze oratorium, wzorowane na turyńskim, otwarto dopiero w Przemyślu (na Zasaniu). Salezjanie do momentu rozpoczęcia działalności w tym mieście, tj. do $1907 \mathrm{r}$. zajmowali się organizacją placówki o charakterze oratoryjnym. Po wybudowaniu odpowiedniego budynku w 1911 r. rozpoczęto regularną działalność oratoryjną pod kierownictwem ks. Stanisława Krygiera ${ }^{310}$.

Placówki salezjańskie otwarte w latach międzywojennych, prawie wszystkie prowadziły oratorium. Jedne $\mathrm{z}$ nich zajmowały się działalnością oratoryjną (Kraków-Dębniki, Lublin, Lwów, Mysłowice, Poznań), inne prowadziły ją równorzędnie z pracą w internatach (Kielce, Ostrzeszów, Kraków-Łosiówka, Kraków-Rakowicka 27). W schronisku Lubomirskich, obok bursy, otwarto w 1926 r. oratorium dla młodzieży z miasta, która po zajęciach w szkole lub po pracy

308 Św. J a n B os k o, Wspomnienia oratorium, Warszawa 1987; Ustawy i Regulaminy, art. 377-405 (Reg.); Oratoria czyli kaplice świateczne, WS, 15 (1911) nr 3, s. 61.

309 ArITSK, 1520 Oświęcim. Kronika Zakładu Salezjańskiego w Oświęcimiu od 21 VIII 1898 r. (I 1899 - V 1900); 25-lecie, s. 10-13.

310 S 1 ó s a r czy k, dz. cyt., t. 1, s. 244-246. 
mogła korzystać w świetlicy oratoryjnej z dobrej rozrywki i pomocy dydaktycznej. Początkowo oratorium było przewidziane na około stu chłopców ${ }^{311}$.

Ksiądz Bosko wymagał, by w oratorium panowała atmosfera rodzinna, by dyrektor oratorium, odpowiedzialny za całość, był dla każdego bratem, ojcem i przyjacielem. Wspomniane oratorium działało przy schronisku, stąd każdorazowy dyrektor zakładu był równocześnie dyrektorem oratorium. Miał on do pomocy zgodnie z Ustawami i Regulaminami Towarzystwa stałego zastępcę, katechetę i asystenta. W praktyce wymienione funkcje pomocnicze wypełniał kleryk z Wyższego Seminarium Duchownego Towarzystwa Salezjańskiego, zwany asystentem, odbywający przepisaną praktykę pedagogiczną ${ }^{312}$, sprawował on bezpośredni nadzór nad oratoriami.

Młodzieży nie brakowało, a jedynym mankamentem była szczupłość pomieszczeń, nie pozwalająca na pełną swobodę działania. Od początku, tj. od 1926 r. stu oratorianów różnego wieku i zawodu podzielono na dwie grupy: starszych i młodszych, odbywających regularnie, co miesiąc, swe zebrania ${ }^{313}$. Wśród oratorianów rozwinęła się działalność na polu organizacyjnym. Działało tu kilka sekcji: sportowa, dramatyczna, muzyczna, Koło Młodzieży Misyjnej im. Dominika Savio. Inicjatorami tego koła, o którym już wcześniej była mowa, byli oratorianie ze Szkoły Podstawowej Św. Mikołaja. Prezesem został wybrany Zbigniew Dobrzański ${ }^{314}$.

Podobnie jak każde oratorium, tak i oratorium przy schronisku, posiadało swój regulamin (tymczasowo uchwalony 18 II 1932 r.) i rozkład dnia. Zaprowadzona lista członkowska $\mathrm{z}$ każdym dniem wydłużała się. W przeważającej mierze byli to uczniowie ze wspomnianej już Szkoły Podstawowej Św. Mikołaja w Krakowie. Stanowili oni $75 \%$ oratorianów. Każdego dnia, już od godziny 13.30 przychodzili chłopcy z podręcznikami szkolnymi i do godziny 15.00 uczyli się pod nadzorem asystenta, który służył im również pomocą w przygotowywaniu wypracowań szkolnych. Godziny otwarcia oratorium i czas przeznaczony na naukę oraz zabawę ulegały w poszczególnych latach nieznacznym zmianom. Po skończonej nauce był czas przeznaczony na godziwą rozrywkę i zabawę. Zabawy i gry były dostosowane do pór roku. W lecie i jesieni grano w piłkę ręczną, siatkówkę i koszykówkę. Późną jesienią i zimą wystawiano sztuki amatorskie (jasełka grano każdego roku wspólnie $\mathrm{z}$ sekcją dramatyczną Towa-

311 ArITSK, T. Lubomirscy. Sprawa przejęcia zakładu przed I i po I wojnie światowej, Projekt warunków na jakich zgromadzenie podjęłoby się administracji zakładu - z $1923 \mathrm{r}$.

${ }^{312}$ ArITSK, T. Oratorium - Salezjański Dom Młodzieży Kraków, Kronika działalności oratorium w schronisku.

313 Tamże, Arkusz, rejestracyjny; Salezjański Dom Młodzieży. Kraków Rakowicka 27, PS, 13 (1929) nr 3, s. 89-90.

${ }^{314}$ ArITSK, T. Oratorium - Salezjański Dom Młodzieży Kraków, Kronika Towarzystwa Młodzieży Misyjnej im. Dominika Savio. 
rzystwa Sportowego „Orlęta” z zakładu), grano w ping-pong, w gry pokojowe, szachy itp. Szczególnie przygotowywano się do organizowania wieczerzy wigilijnej i „gwiazdki”. Od 1931 r., podczas tych imprez, wręczano oratorianom nagrody za regularne uczęszczanie i wzorowe zachowanie w oratorium. Latem $\mathrm{z}$ kolei życie oratorium koncentrowało się raczej na boisku sportowym, a gdy nie pozwalały na to warunki atmosferyczne, przenoszono się do świetlicy oratoryjnej. Dużym zainteresowaniem cieszyły się organizowane turnieje: szachowe, ping-ponga, koszykówki, wyzwalające w młodzieży zdrową rywalizację. Oratorium posiadało własną bibliotekę, liczącą kilkadziesiąt pozycji, przy której otwarto również czytelnię prenumerującą sześć czasopism katolickich ${ }^{315}$.

W latach międzywojennych oratorium niejednokrotnie borykało się z trudnościami materialnymi. Księża dyrektorzy, głównie ks. Józef Liszka, mimo to popierali tę działalność, na ile tylko było ich stać. Staraniem ks. Liszki znacznie zwiększono ilość gier i liczbę książek w bibliotece. W 1929 r. ufundował on nowe stroje sportowe dla dwóch drużyn piłki ręcznej.

Szczególnie dotkliwie dała się we znaki zima 1928/1929. Oratorium z braku opału nie było wówczas czynne przez dwa miesiące ${ }^{316}$.

Cała społeczność oratoryjna obchodziła swe największe święto ku czci patrona Dominika Savio. Wszyscy czuli się odpowiedzialni za przygotowanie uroczystej akademii z okolicznościowym przedstawieniem na zakończenie.

Tab. nr 40: Liczba oratorianów w latach 1924-1937

\begin{tabular}{|c|c|}
\hline rok & oratorianie \\
\hline XII 1924 & 25 \\
\hline 1925 & 54 \\
\hline 1926 & 91 \\
\hline 1927 & 120 \\
\hline 1928 & 116 \\
\hline 1933 & 315 \\
\hline 1934 & 335 \\
\hline 1935 & 127 \\
\hline 1936 & 164 \\
\hline 1937 & 250 \\
\hline
\end{tabular}

Źródło: ArITSK, B 1303 Kronika w schronisku Lubomirskich 1924-1926 (4 XII 1924 - XI 1926).

315 ArITSK, B 1504 Schronisko Lubomirskich. Kronika 1927-1950 (25 IX 1931); Salezjański Dom Młodzieży. Kraków Rakowicka 27, PS, 13 (1929) nr 3, s. 90; Z życia Oratorium, „Echo Bursy", 2 (1927) nr 4, s. 7.

316 Salezjański Dom Mtodzieży - Oratorium, „Echo Bursy”, 4 (1929) nr 3-4, s. 4-5. 
Oratorium, jak powyższa statystyka wskazuje, na początku lat trzydziestych przeżywało swój okres szczególnej prężności. Była to zasługa głównie dyrektora ks. Sylwestra Króla (1932-1936) ${ }^{317}$.

Od 1932 r. funkcjonowało w oratorium kino. Wyświetlano filmy o tematyce religijnej i przyrodniczej, wypożyczane z Domu Katolickiego. W samym tylko styczniu - lutym 1932 r. wyemitowano ich 11. Dnia 15 II 1932 r. ukazał się pierwszy numer „Ruchomej Gazetki”, wydawanej przez oratorium. Składała się ona $\mathrm{z}$ ciekawszych wycinków gazet i czasopism. Na początku marca tego roku zorganizowano chór oratoryjny pod kierownictwem ówczesnego kapelmistrza Olszewskiego. Ta bogata działalność rakowickiego oratorium była możliwa dzięki bardzo dobrym warunkom lokalowym, po przeniesieniu go we wrześniu 1931 r. do odpowiednich, zwolnionych przez dotychczasowych lokatorów ${ }^{318}$.

Działalność oratoryjna, prowadzona przy schronisku Lubomirskich, zasłużyła na poparcie i uznanie ze strony społeczeństwa. Jednym z dowodów była subwencja udzielona mu przez Krakowską Sekcję Opieki Powszechnej Ligi Katolickiej w wysokości 150 zł. Również Towarzystwo Akcji „Elektryczność” w Ząbkowicach przesłało pewną sumę na cele oświatowe ${ }^{319}$.

Pracę oratoryjną przerwała II wojna światowa, a po jej zakończeniu i po ponownym objęciu administracji schroniska przez salezjanów działało ono jeszcze przez prawie 4 lata, ze 150 chłopcami w $1948 \mathrm{r}^{320}$, aż do czasu przejęcia świetlicy przez Szkołę Podstawową św. Mikołaja i oddania zakładu na potrzeby wyższej uczelni.

Działalność oratorium przy schronisku spełniała zapewne swoją rolę. Przebywało w nim wielu chłopców, którzy pożytecznie spędzali tu czas. Młodzież otrzymywała, oprócz pomocy w nauce, dużą porcję rozrywki - tej szczególnie, którą bardzo lubiła ruchowej. W ruchu bowiem i w rywalizacji na boisku, czy w teatrze uwidaczniały się instynkty, które, pod kontrolą asystenta, temperowano i zwalczano. Życie religijne, bo o takie głównie chodziło kształtowano i pogłębiano w czasie konferencji, cotygodniowej katechezie i poprzez osobisty kontakt z wychowawcą.

\section{Organizacja Byłych Wychowanków Salezjańskich}

Do organizacji młodzieżowych zakładów salezjańskich należało koło Byłych Wychowanków Salezjańskich. Członkowie tej organizacji rekrutowali się

317 ASC, S. 38 Kraków Patroncinio B. Vergine, Statistiche - Oratorium.

${ }^{318}$ Ich usuwanie nie odbyło się bez procesów sądowych. ArITSK, B 1504 Schronisko Lubomirskich. Kronika 1927-1950 (28 IX 1931, 15 I, 15, 18 II, 1 III 1932).

${ }^{319}$ Salezjański Dom Mlodzieży - Oratorium, „Echo Bursy”, 4 (1929) nr 3-4, s. 5.

${ }^{320}$ ArITSK, T. Oratorium - Salezjański Dom Młodzieży Kraków, Sprawozdanie z 9 XII 1948 r. 
z uczniów, którzy opuścili szkołę jako absolwenci lub przed jej ukończeniem, czy przebywali w zakładzie jako wychowankowie.

Genezy, rozwiniętej dziś na skalę światową, organizacji Byłych Wychowanków Salezjańskich należy szukać we Włoszech w 1870 roku $^{321}$, kolebce zgromadzenia. Motywację i potrzebę jej istnienia podaje ks. Bosko w swoim traktacie o systemie zapobiegawczym w wychowaniu młodzieży. „Wychowawca tak powinien formować wychowanka stwierdza ks. Bosko by mógł on oddziaływać na niego nie tylko w czasie pobytu w zakładzie, ale i później. Wychowawca, pozyskawszy raz wychowanka, będzie mógł wywierać na niego wpływ, a więc: doradzać, ostrzegać i upominać go nawet wtedy, gdy ten opuści zakład. Wychowanie, to nie tylko kształtowanie charakteru w wieku młodzieńczym. Powinno się ono przedłużać na dalsze etapy życia ludzkiego przez zachowanie i pogłębianie zasad wszczepionych w młodości"322. Ksiądz Bosko nie tylko przewidział powstanie tej organizacji, ale uważał ją za integralną część swego dzieła i konsekwencję swego systemu wychowawczego.

W Polsce pierwsze koło BWS powstało w 1911 r. Uroczystości odpustowe św. Jacka w Oświęcimiu w 1910 r. zgromadziły grono wcześniejszych wychowanków zakładu. Po odbytym zebraniu koleżeńskim, powzięli oni pierwsze kroki, zmierzające do zorganizowania koła BWS przy zakładzie w Oświęci$\mathrm{miu}^{323}$. W roku następnym na uroczystości odpustowe zjechało się jeszcze liczniejsze grono byłych wychowanków. Korzystając z okazji, odbyli oni posiedzenie $\mathrm{z}$ inspektorem i zarazem dyrektorem zakładu ks. dr. Emanuelem Manassero. Ustalili też datę walnego zjazdu na 15 X $1911 \mathrm{r}$. oraz wybrali tymczasowy komitet ${ }^{324}$, odkładając na później wybór władz koła i uchwalenie statutu do przyszłego walnego zjazdu.

Na jubileusz dziesięciolecia zakładu w Oświęcimiu 15 X 1911 r. przybyło sześćdziesięciu byłych wychowanków oświęcimskich, osiemdziesięciu przedstawicieli z zakładu księcia Lubomirskiego z Krakowa ${ }^{325}$, a także wychowankowie pozostałych zakładów, sympatycy i dobrodzieje salezjanów w Polsce. Na uroczystość tę przybył z Turynu generał zgromadzenia ks. Paweł Albera. W tym samym dniu na specjalnie zorganizowanym wieczorku powołano koło Byłych Wychowanków Salezjańskich w Oświęcimiu ${ }^{326}$. Prezesem został wybrany Józef Kasolik. W skład zarządu weszli: wiceprezes Jan Palonek, sekre-

321 Don Bosco nel mondo, Torino 1964, s. 132.

${ }^{322}$ Wyjątek z listu ks. Bosko z Rzymu z 10 V 1884 r. do salezjanów w Turynie. Zob. L. Cian, Wychowanie w duchu ks. Bosko, Warszawa 1991, s. 185-209.

323 ArZSO, T. Kronika Zakładu Salezjańskiego w Oświęcimiu, t. 2 (1910).

${ }^{324}$ ArZSO, T. BWS, Odezwa Komitetu Tymczasowego z 21 VII 1911 r.

${ }^{325}$ Odstonięcie pomnika X pratata Andrzeja Knycza, WS, 15 (1911) nr 12, s. 328.

${ }^{326}$ Tamże, s. 332; 25-lecie, s. 21-23. 
tarz kl. Kazimierz Olszewski salezjanin, skarbnik Jan Dołęgowski. Zatwierdzenie organizacji BWS i jej statutu przez Namiestnictwo we Lwowie nastąpiło dopiero 27 kwietnia 1913 roku $^{327}$. Zarząd, którego kadencja trwała dwa lata, miał odbywać posiedzenia w pierwszą niedzielę kwartału (styczeń, kwiecień, lipiec, październik). Natomiast raz do roku organizowano walny zjazd wszystkich wychowanków w Zakładzie im. Ks. Bosko w Oświęcimiu. Członkowie podzieleni byli na honorowych, zwyczajnych (rzeczywistych) i nadzwyczajnych. Energiczną działalność koła BWS w Oświęcimiu przerwała pierwsza wojna światowa. Po ośmioletniej przerwie, $\mathrm{z}$ myślą przywrócenia dawnego koła do życia, zjechała się do Oświęcimia 11 czerwca 1922 r. grupa byłych wychowanków. Utworzyli oni komitet tymczasowy, którego zadaniem było ponowne zorganizowanie związku BWS ${ }^{328}$. Na dzień 20 sierpnia 1922 r. wyznaczono datę pierwszego walnego zjazdu powojennego. Zapowiedziany zjazd zgromadził prawie 300 wychowanków wszystkich zakładów salezjańskich w Polsce. Owocem zjazdu było utworzenie czterech kół BWS w Polsce, przy zakładach: w Krakowie (na Dębnikach), Oświęcimiu, Przemyślu i w Warszawie ${ }^{329}$.

Najliczniejsze było koło oświęcimskie; liczyło 114 członków, koło krakowskie - 58 członków. Wychowankowie ze schroniska stanowili prawie $50 \%$ członków koła. Rekrutowali się oni z grupy terminatorów, którzy, po wybuchu pierwszej wojny światowej i zajęciu przez wojsko zakładu, zamieszkali u mistrzów krakowskich, dla kontynuowania praktyki zawodowej. O spoistość i energiczną działalność koła krakowskiego zabiegał dr Julian Wilk, który na walnym zjeździe w Oświęcimiu w 1922 r. wybrany został prezesem koła BWS w Krakowie.

Dalszym krokiem, zmierzającym do konsolidacji działalności, był zjazd delegatów kół zakładowych w Oświęcimiu 13 lipca 1923 r. Celem zjazdu było ukonstytuowanie kół w Polsce w nowych warunkach odrodzonej Polski. Prezes koła oświęcimskiego przedstawil potrzebę utworzenia Związku kół BWS w Polsce, za czym przemawiał międzynarodowy statut BWS. Projekt Związku i jego statut przyjęli delegaci. W myśl statutu członkami Związku są koła BWS, istniejące przy zakładach salezjańskich. Zarząd Związku kół BWS w Polsce stanowili prezesi czterech kół z księdzem inspektorem lub delegatem na czele. Pierwszy Zarząd Główny w odrodzonej Polsce tworzyli: prezes Józef Kasolik prezes koła oświęcimskiego, wiceprezes Julian Wilk prezes koła krakowskiego, sekretarz ks. Ignacy Antonowicz. Najważniejszym zadaniem nowego zarządu

${ }^{327}$ ArZSO, T. BWS, Dyrektor zakładu do c.k. Namiestnictwa o zatwierdzenie związku BWS 22 IV $1913 \mathrm{r}$.

${ }^{328}$ ArZSO, T. BWS, Zaproszenie na zjazd do Oświęcimia 9 maja 1922 r. podpisane przez ks. I. Antonowicza, Kraków ul. Tyniecka 55.

${ }^{329}$ ArZSO, T. BWS, Sekretariat komitetu zjazdowego BWS w Polsce informuje o Walnym Zjeździe 20 VIII 1922 r.; 25-lecie, s. 28-29. 
było zorganizowanie kongresu BWS w Polsce w sierpniu tegoż roku. Kongres rzeczywiście odbył się w dniach 17-19 sierpnia 1923 r. w Oświęcimiu i zbiegł się z obchodami dwudziestopięcioletniej działalności salezjańskiej w Polsce. Ukoronowaniem kongresu było odsłonięcie tablicy, wmurowanej na zachodniej ścianie zakładu i poświęcenie popiersia ks. Bosko na placu przed kaplicą św. Jacka. Był to wymowny gest byłych wychowanków, pragnących, „by jak się wyraził prezes Związku zamanifestować wobec społeczeństwa swój hołd i wdzięczność dla księdza Bosko i jego zgromadzenia"330.

W 1925 r. siedzibę zarządu koła krakowskiego przeniesiono z domu zakonnego przy ul. Tynieckiej 55 do schroniska. Dnia 10 stycznia 1926 r. odbyło się zebranie zarządu Koła, na którym zajęto się przygotowaniem walnego zebrania. Datę zebrania wyznaczono na 2 lutego 1926 r. Przybyło 50 członków. Spotkanie to, jak każde inne, rozpoczęto mszą św. o godz. 9.30. Obradom przewodniczył radca Pruszyński. Prezesem na trzecią, kolejną kadencję wybrano jednogłośnie Juliana Wilka. Mając na uwadze cel Związku - życie chrześcijańskie - koło krakowskie zorganizowało w dniach 18-21 marca $1926 \mathrm{r}$. rekolekcje w schronisku. W godzinach wieczornych, w czasie nabożeństwa, nauki głosił ks. Cieślar. Dnia 21 marca, na zakończenie rekolekcji odegrano „Obrazy Męki Pańskiej”, wystawiane po raz pierwszy na scenie zakładowej ${ }^{331}$.

Członków stowarzyszenia BWS łączyły ścisłe więzy przyjacielskie, niemal rodzinne, okazywane przez udzielanie sobie wzajemnej pomocy moralnej i materialnej. Koło dysponowało odpowiednimi środkami finansowymi z rocznych składek członkowskich. Ponadto koło krakowskie otworzyło własne konto bankowe, na które można było przesyłać kwoty pieniężne. Z pieniędzy tych udzielano pomocy finansowej członkom znajdującym się w trudniejszych sytuacjach życiowych, zwłaszcza w okresie poszukiwania pracy, o którą wtedy nie. było ła two. Działało również biuro prasowe, które członkom koła ułatwiało jej zdobycie. O rodzinnej atmosferze i poczuciu wzajemnej odpowiedzialności członków świadczy fakt, że na miarę swego wykształcenia, zawodu i zajmowanego stanowiska udzielali sobie wzajemnie rad i pomocy, np. lekarskiej, prawnej itp. Wszystkie te poczynania, podejmowane bezinteresownie, służyły wzajemnej pomocy i prowadziły do konsolidacji członków koła. Działały w nim sekcje: dramatyczna z kierownikiem Rojakiem i muzyczna z T. Czaplą. Angażowały się one w imprezy artystyczne, organizowane przez kółka i towarzystwa młodzieżowe w schronisku, z których dochód przeznaczano na rzecz zakładu.

W trzy lata później liczba członków koła krakowskiego zwiększyła się trzykrotnie, osiągając w grudniu 1929 r. liczbę 162. Bardzo miłą uroczystością dla koła były prymicje, jakie odprawił w bursie ks. Marian Mączyński

${ }^{330}$ ArZSO, Kronika zakładu od r. Pańskiego 1926 (z przemówienia J. Kasolika 19 VIII $1923 \mathrm{r}$.).

331 ArITSK, B 1303 Kronika w schronisku Lubomirskich 1924-1926 (19-21 III 1926). 
24 sierpnia 1927 r., były wychowanek zakładu. Wstąpił do zgromadzenia salezjańskiego i po skończonych studiach teologicznych w Turynie, po powrocie do Polski, przybył do wychowanków zakładu - których nazwał się „starszym bratem" - by odprawić prymicje $\mathrm{e}^{332}$.

Dzięki życzliwości ks. dyr. J. Liszki i ks. prefekta A. Sękowskiego, koło krakowskie otrzymało 15 grudnia 1929 r. osobny lokal do swojej dyspozycji w willi przy ul. Lubomirskiego. Otwarty byl codziennie w godzinach 12.00 $22.00^{333}$.

Na walnym zebraniu w październiku 1930 r. dokonano podsumowania dotychczasowego dorobku koła krakowskiego, po jego ośmioletniej działalności. Chociaż koło nie imponowało wysokimi liczbami statystycznymi, to jednak jego osiągnięcia były dziełem wysiłku i poświęcenia tak zarządu, jak i każdego z członków. W zebraniu wziął udział przedstawiciel zgromadzenia ks. Józef Oleksy, główny sekretarz do spraw Związku BWS w Polsce i dyrektor schroniska ks. A. Kazimierczak. Skończyła się kadencja dawnego zarządu. Nastąpiła zmiana na stanowisku prezesa. Pełniący tę funkcję przez cztery kolejne kadencje ofiarny J. Wilk (1922-1930) ustąpił. Jego miejsce zajął Rudolf Rosiński, jeden z pierwszych wychowanków zakładu w Oświęcimiu, wiceprezesem został Władysław Jankowski, były wychowanek zakładu w Turynie, Andrzej Pałka został sekretarzem, a Mieczysław Ratter skarbnikiem ${ }^{334}$.

W 50 rocznicę śmierci założyciela zgromadzenia (kanonizowanego w 1934 r.), przypadającą w 1938 r., krajowy Związek BWS zorganizował Kongres Pomocników i Byłych Wychowanków Salezjańskich na Jasnej Górze w Częstochowie, w dniach 7-8 maja 1938 r. Celem kongresu było odśpiewanie dziękczynnego „Te Deum” za 40-letnią pracę salezjanów w Polsce i uproszenie błogosławieństwa na dalsze lata oraz uczczenie św. Jana Bosko przez zapoznanie społeczeństwa polskiego $\mathrm{z}$ charyzmatem $\mathrm{i}$ duchem założonego przez siebie zgromadzenia i jego metodą wychowawczą. Protektorat nad kongresem objęli J. E. kard. August Hlond, prymas Polski, salezjanin i J. E. ks. bp Teodor Kubina, ordynariusz częstochowski. Przybyły pielgrzymki pomocników i byłych wychowanków z Kielc, Lwowa, Łodzi, Mysłowic, Oświęcimia, Poznania, Przemyśla, Sokołowa i Warszawy. W kongresie brało udział około 15 tys. wiernych, w tym ponad 1500 wychowanków salezjańskich i około 500 byłych wychowanków schroniska, 7 salezjanów pracujących przy ul. Rakowickiej 27 oraz 40 wychowanków ${ }^{335}$.

\footnotetext{
332 Prymicje, „Echo Bursy”, 2 (1927) nr 7-8, s. 6.

333 ArITSK, B 1504 Schronisko Lubomirskich. Kronika 1927-1950 (15 XII 1929).

${ }^{334} Z$ życia B.W.S. $w$ Krakowie, PS, 15 (1931) nr 12, s. 18.

${ }^{335}$ ArITSK, B 1504 Schronisko Lubomirskich. Kronika 1927-1950 (7 V 1938); Kongres Po-
} mocników i Bytych Wychowanków Salezjańskich na Jasnej Górze w Częstochowie, PS, 22 (1938) nr 6, s. 137-154. 
$\mathrm{Na}$ osiem miesięcy przed wybuchem II wojny światowej odbyło się walne zebranie koła krakowskiego. W niedzielę 16 grudnia 1938 r. zakład księcia Lubomirskiego zgromadził około 100 byłych wychowanków z Krakowa i okolicy. Przybyli także delegaci z Katowic, Lodzi, Poznania. Po referacie Józefa Hołdy „O zadaniach i celach organizacji BWS" głos zabrał prezes zrzeszenia na całą Polskę, sędzia J. Kasolik z Krakowa. Na zakończenie przystąpiono do wyboru nowego zarządu koła miejscowego. Prezesem został J. Hołda, wiceprezesem dr J. Wilk, sekretarzem Stanisław Gawel ${ }^{336}$.

W 1938 r. siedzibą Zarządu Głównego Związku BWS w Polsce zostało schronisko Lubomirskich.

W czasie II wojny światowej organizacja BWS oficjalnie przestała istnieć. Nieoficjalnie jednak działała dalej. Członkowie jej udzielali sobie wzajemnej pomocy materialnej, a nawet $\mathrm{z}$ narażeniem życia, wstawiali się za sobą u władz niemieckich. Po wojnie, mimo że zakład działał tylko kilka lat, członkowie BWS ujawniali żywą działalność, głównie przez niesienie pomocy materialnej zgromadzeniu. W miarę swych możliwości ułatwiali salezjanom załatwianie trudnych problemów w nowej rzeczywistości polityczno-społecznej. Skupiali się dalej przy salezjanach krakowskich, którzy nieśli im wsparcie moralne w nowych, niełatwych czasach. Trzeba nadmienić, że do dzisiejszego dnia byli wychowankowie obecnej prowincji salezjańskiej pw. św. Jacka organizują swoje doroczne zjazdy w zakładzie w Oświęcimiu. Nie ma przesady w stwierdzeniu, iż o taką właśnie postawę wobec życia i o taką formację duchową chodziło św. Janowi Bosko.

\section{ZAKOŃCZENIE}

Schronisko im. księcia Aleksandra Lubomirskiego, otworzone w 1893 r., w miarę upływu lat zmieniało nieco profil swojej działalności, dostosowując go do aktualnych potrzeb środowiska. W latach 1893-1928 schronisko dawało wychowankom przede wszystkim utrzymanie, wykształcenie w zakresie szkoły podstawowej oraz zapewniało możliwość uzyskania kwalifikacji zawodowych u rzemieślników miasta Krakowa i okolic. Była to działalność zgodna $\mathrm{z}$ oczekiwaniami fundatora.

W okresie II Rzeczypospolitej, w odpowiedzi na zwiększone zapotrzebowanie społeczne na wykwalifikowanych rzemieślników, w 1928 r. salezjanie otworzyli w schronisku Szkołę Rzemieślniczo-Przemysłową, w której w 1931 r. dział ogrodniczy usamodzielnił się i powstała Publiczna Szkoła Dokształcająca Zawodowa nr 24 dla ogrodników. W trosce o wszechstronny rozwój wy-

${ }^{336}$ Ze świata salezjańskiego: Walne zebranie Byłych Wychowanków Salezjańskich w Krakowie, PS, 22 (1938) nr 12, s. 272. 
chowanków, salezjanie rozwijali w schronisku różnorodne formy działalności kulturalnej, dbali o sprawność fizyczną swoich podopiecznych, a przede wszystkim zwracali baczną uwagę na rzetelne wychowanie w duchu religijnym, stosując wobec podopiecznych system wychowawczy ks. J. Bosko, zwany systemem zapobiegawczym. Kilkutysięczna rzesza wychowanków, rekrutująca się w większości spośród najbiedniejszych i z tzw. marginesu społecznego, świadczy o poważnym wkładzie schroniska w akcję społeczną Kościoła w Polsce.

Dzieje fundacji i jej dorobek wykazują także niezbicie, że zakład ten, podobny do innych, znajdujących się w gestii duchowieństwa, nie był instytucją dochodowa, jak głoszą to pewne bezpodstawne i fałszywe opinie rozpowszechniane niejednokrotnie w społeczeństwie. Dla poznania całościowego okresu działalności Kościoła na rzecz najbardziej potrzebujących w okresie II Rzeczypospolitej, warto podjąć dalsze badania nad tego typu instytucjami, które powstawały głównie pod opieką zakonów i zgromadzeń zakonnych.

\section{BIBLIOGRAFIA}

Archiwalia

ARCHIWUM GENERALNE TOWARZYSTWA SALEZJAŃSKIEGO W RZYMIE - ASC

Sygnatury:

S. 38 Kraków Patrocinio B. Virgine

S. 389 Klecza Dolna

\section{ARCHIWUM INSPEKTORIALNE TOWARZYSTWA SALEZJAŃSKIEGO W KRAKOWIE - ArITSK}

\section{Sygnatury:}

A 11 Likwidacja. Schronisko Lubomirskich

A 532 Schronisko im. ks. A. Lubomirskiego. Pensje chłopców 1928-1938 i długi 1931-1938

A 533 Schronisko im. ks. A. Lubomirskiego. Wykaz wychowanków. Ich pensje. Stałe niedobory

A 534 Schronisko im. A. Lubọmirskiego. Wykaz wychowanków na utrzymaniu: Wydziału Powiatowego, Kuratorium-Wydział Opieki, Skarbu Państwa 19471950

A 539 Schronisko im. ks. A. Lubomirskiego. Spis wychowanków 1912-1939, 19461950

A 548 Schronisko im. ks. A. Lubomirskiego 
A 550 Schronisko fundacji ks. A. Lubomirskiego w Krakowie. Księga wizytacyjna kuratorii schroniska od 12 XII 1896 r. do 12 VIII 1914 r.

A 554 Sprawozdanie $\mathrm{z}$ czynności schroniska fundacji ks. A. Lubomirskiego za lata 1893-1949

A 556 Kraków-Rakowicka 27. Schronisko im. ks. A. Lubomirskiego. Harcerstwo

A 563 Kraków-Rakowicka 27. Schronisko im. ks. Lubomirskiego. Wizytacje inspektorialne 1934-1938, 1945-1947

A 581 Kraków-Rakowicka 27. Katalog główny z wykazem klasyfikacyjnym od 1894 do $1903 \mathrm{r}$

A 582 Kraków-Rakowicka 27. Schronisko im. ks. A. Lubomirskiego. Katalog główny $1903-1911$

A: $586,586 \mathrm{a}, 586 \mathrm{~b}, 587 \mathrm{~b}, 588,588 \mathrm{a}, 588 \mathrm{~b}, 589,589 \mathrm{a}, 589 \mathrm{~b}$ Lubomirscy. Szkoła dla ogrodników

A 602 Schronisko im. Lubomirskiego. Szkoła ogrodnicza

A 604 Schronisko im. Lubomirskiego. Szkoła ogrodnicza

A 606 Schronisko im. A. Lubomirskiego. Program Publicznej Szkoły Dokształcającej Zawodowej nr 24 dla ogrodników w Krakowie

A 607 Schronisko im. A. Lubomirskiego. Szkoła ogrodnicza

A 617 Kraków-Rakowicka 27. Schronisko im. ks. A. Lubomirskiego. Katalog klasowy 1911-1914

A 618 Lubomirscy. Katalog klasyfikacyjny 1896-1903

A 627 Schronisko Lubomirskich

A 634 Schronisko im. księcia A. Lubomirskiego. Szkoła szewska 1926-1939

A 636 Schronisko im. A. Lubomirskiego. Komisja egzaminaczyjna

A 637 Schronisko im. Lubomirskich. Szkoła szewska. Egzamin czeladniczy 19291939

A 647 Schronisko Lubomirskiego. Kuratorium 1939

B 1303 Kronika w schronisku Lubomirskich 1924-1926

B 1503 Kraków - Lubomirscy. Kronika

B 1504 Schronisko Lubomirskich. Kronika 1927-1950

1520 Oświęcim Kronika Zakładu Salezjańskiego w Oświęcimiu od 21 VIII 1898 r.

Akta bez sygnatury:

Dobrodzieje schroniska Lubomirskich

Dyrekcja zakładu Lubomirskich

Fundacja Lubomirskiego. Finanse

Harcerstwo. Kraków-Rakowicka 27

Lubomirscy

Lubomirscy. Kuratorium Szkolne Krakowskie

Lubomirscy. Magistrat Krakowski

Lubomirscy. Sprawa przejęcia zakładu przed I i po I wojnie światowej

Nekrologi

Oratorium - Salezjański Dom Młodzieży Kraków

Oświęcim. Szkoła Rzemiosł 
Przejęcie zakładu Lubomirskich

Schronisko im. ks. A. Lubomirskiego

Schronisko fundacji Lubomirskich

Schronisko Lubomirskich

Lubomirscy. Szkoła rzemieślnicza

Szkoła szewska. Lubomirskich

Zakład księcia Aleksandra Lubomirskiego w Krakowie

Zakład Lubomirskich

Zakład Lubomirskich. Organizacje młodzieżowe

\section{ARCHIWUM KURII METROPOLITALNEJ W KRAKOWIE - AKMKr}

Zespół: Zakony - Klasztory

Sygnatury:

202 Salezjanie

AF 318 Akta Fundacji 1940

\section{ARCHIWUM SIÓSTR MLOSIERDZIA W KRAKOWIE - AKMK (b.s.)}

Akta bez sygnatury:

Siostry Miłosierdzia. Zakład Lubomirskich

Schronisko Lubomirskich

Zakład Lubomirskich

\section{ARCHIWUM ZAKtADU SALEZJAŃSKIEGo W OŚWIĘCIMIU - ArZSO (b.s.)}

Akta bez sygnatury:

BWS

Kronika zakładu od r. Pańskiego 1926

Kronika Zakładu Salezjańskiego w Oświęcimiu, t. 2

Prasa

„Czas”, 64 (1911) nr 167.

„Echo Bursy Salezjańskiej fund. Ks. Al. Lubomirskiego”, 1 (1926) - 5 (1930).

„Głos Narodu”, 32 (1925) nr 248.

„Nostra”, 28 (1973) - 29 (1974).

„Pokłosie Salezjańskie”, 1 (1916) - 24 (1946).

„Wiadomości Salezjańskie”, 15 (1911) nr 12.

\section{LITERATURA}

Bar J., Zgromadzenie Matki Bożej Miłosierdzia, w: Rozwój stanów doskonatości w Polsce, Warszawa 1966, s. 27-184. 
Bartosiewicz J., Zarys historyczny opieki nad ubogimi w Galicji od czasu przytaczenia jej do Austrii aż po chwile obecnq, w: Wiadomości Statystyczne o Stosunkach Krajowych, red. T. Pilat, t. 18, Lwów 1901, s. 7-21.

B(artynowski) M., Nowakowski Wactaw (Edward), w: Podręczna Encyklopedia Kościelna, Warszawa 1913, red. Z. Chełmicki, t. 29-30, s. 81-82.

Bieniarzówna J., Lubomirski Aleksander, PSB, t. 18, Wrocław 1973, s. 2.

Bieniarzówna J., Małecki J., Dzieje ziemi krakowskiej w wypisach, Warszawa 1956. Bima F., Ks. Kazimierz. Siemaszko twórca dzieła mitości i poświęcenia, „Caritas”, 3 (1947) $\mathrm{nr}$ 4, s. 107-112.

Boy-Żeleński T., Znasz-li ten kraj, Kraków 1932.

Braido P., Il sistema proventivo di don Bosco, Zurich 1964.

Braido P., System wychowawczy księdza Bosko, Warszawa 1971, mps.

Bujak F., Galicja, t. 2, Lwów 1910.

Cian L., System zapobiegawczy Sw. Jana Bosko, Warszawa 1986.

Cian L., Wychowanie w duchu ks. Bosko, Warszawa 1991.

Demel J., Podstawy rozwoju nowoczesnego Krakowa w latach 1846-1956, w: Kraków, jego dzieje i sztuka, red. J. Dąbrowski, Warszawa 1965, s. 439-498.

Dobrzański S., Restauracja diecezji krakowskiej w latach osiemdziesiatych XIX w., w: Studia z historii Kościoła w Polsce, t. 3, Warszawa 1977, s. 11-269.

Don Bosco nell mondo, Torino 1964.

Dutkowa R., Szkolnictwo średnie Krakowa w pierwszej połowie XIX w. (1801-1846), Wrocław 1976.

25-lecie dziatalności salezjańskiej w Polsce, Mikołów 1923.

Dziesięciolecie działu grafiki Salezjańskiej Szkoty Rzemiost w Warszawie 1923-1933, Warszawa [brw].

„Elenco della Societa di San Francesco di Sales”, 1926-1940, 1947, 1950.

Espinay K., Ksiądz Bosko, Lwów 1886.

Francic M., Kalendarz dziejów Krakowa, Kraków 1864.

Galicyjskie wspomnienia szkolne, red. Z. Haraschin-Gutkowska, do druku przygotował i wstępem opatrzył A. Knot, Kraków 1955.

Gaworzewski J., Przez 75 lat pracy Stowarzyszenia Pań Mitosierdzia św. Wincentego a Paulo w Krakowie (1855-1930), [bmw] 1930.

Historia Polski, t. 1: 1764-1864, cz. 2: 1795-1831, red. S. Kieniewicz, W. Kula, Warszawa 1956.

Hordyński W., Czartoryska Marcelina, PSB, t. 4, s. 246-248.

Jakubowski Z., Działalność ks. Franciszka Fabera CRL w Krakowie 1853-1868, Kraków 1974.

Kaczmarzyk M., Czartoryski August Franciszek, w: Hagiografia polska, Poznań 1971, t. 1 s. 265-286.

Kalendarz katolicki na rok Pański 1889, Kraków.

Kieniewicz S., Czyn Polski w dobie Wiosny Ludów, Warszawa 1948.

Kieniewicz S., Galicja w dobie autonomicznej, Wrocław 1952.

Kieniewicz S., Historia Polski 1795-1918, Warszawa 1983.

Kieniewicz S., Konspiracje galicyjskie (1831-1845), Warszawa 1950. 
Konopnicki J., Wychowanie fizyczne w szkole polskicj na przełomie XVIII $i$ XIX w., w: Wychowanie fizyczne i sport, t. 1, Warszawa 1957, s. 35-55.

Konstytucje i Statuty Sióstr Miłosierdzia Św. Wincentego a Paulo, [brmw] mps.

Kostanecki, Twórczość architektoniczna Tadeusza Stryjeńskiego na tle epoki, Warszawa 1937.

Krajewski J., Tajne zwiqzki polityczne w Galicji, Lwów 1903.

Krakowski kalendarz Czecha na rok 1891, Kraków.

Krawiec J., Towarzystwo Św. Franciszka Salezego oraz jego organizacja w Polsce, Lublin 1964, mps.

Krzyżanowska Z., Dobroczynność w Krakowie, w: Kraków w XIX wieku.

Ksiądz Bosko opiekun i nauczyciel sierot, Warszawa 1886.

Ksiadz Jan Bosko, Kraków 1889.

Kurdybacha L., Historia wychowania, Warszawa 1961.

Kunowski S., Bursa, w: Encyklopedia katolicka, t. 2, Lublin 1976, kol. 1226-1227.

Kutrzeba S., Ptaśnik J., Dzieje handlu i kupiectwa krakowskiego, Kraków 1910.

Lewicki K., Przytulisko weteranów powstania 1863/64 r. w Krakowie, Kraków 1949. Leymoyne J. Ch., Memorie Biografiche, t. 18, Torino 1937.

Majka J., Kościelna działalność dobroczynna, „Zeszyty Naukowe Katolickiego Uniwersytetu Lubelskiego", 9 (1966) nr 1-2, s. 117-137.

Malinowski Z., Działalność muzyczna salezjanów polskich, w: 75 lat działalności salezjanów w Polsce, red. R. Popowski, S. Wilk, M. Lewko, Łódź-Kraków 1974, s. $110-130$.

Materialy do organizacji szkolnictwa zawodowego, Lwów 1934.

M. O. S., Ksiq̨dz Jan Bosko, Kraków 1889.

Nöel L., Ksiq̨dz Jan Bosko jego żywot i czyny podług różnych źródeł opracowane, Poznań 1887.

Oświata i szkolnictwo w Rzeczypospolitej Polskiej, Warszawa 1929.

Pamiqutka Dnia Młodzieży Misyjnej w Krakowie, red. A. Ogórkiewicz, Kraków 1927.

Pamiatka dwudziestopięciolecia zaktadu salezjańskiego w Daszawie 1905-1930, Warszawa 1930.

Pareński S., Nowe zakłady humanitarne Krakowa, Kraków 1912.

Pelczar J. S., Zarys dziejów milosierdzia w Kościele katolickim, Kraków 1916.

Pirożyński M., Zakony męskie w Polsce, Lublin 1937.

Pływaczyk S., Schronisko dla mtodzieży rękodzielniczej i przemystowej im. ks. A. Lubomirskiego w Krakowie, w: AH, zebrał ks. S. Kosiński, Ląd 1966-1974, t. 6, cz. 14, s. 221-223.

Rederowa D., Kraków porozbiorowy, w: Kraków, jego dzieje i sztuka, red. J. Dąbrowski, Warszawa 1965, s. 397-406.

Sala W., Praca w zakładach opiekuńczo-wychowawczych (w okresie 1918-1939), Warszawa 1964.

Schletz A., Zarys historyczny Zgromadzenia Sióstr Miłosierdzia w Polsce, Kraków 1960

Statut Towarzystwa Salezjańskiego, Warszawa 1933. 
Styrna S., Zgromadzenie Salezjańskie $w$ Polsce $w$ poszukiwaniu formy odpowiedzi na potrzeby wychowawcze i duszpasterskie w latach 1898-1974, w: 75 lat dzialalności salezjanów w Polsce, red. R. Popowski, S. Wilk, M. Lewko, Łódź-Kraków 1974, s. 11-36.

System wychowawczy, Oświęcim 1905.

Szczerba K., Salezjańskie szkoty zawodowe w Polsce 1901-1939, Lublin 1973, mps. Szczepanowski S., Nędza w Galicji w cyfrach $i$ program energicznego rozwoju gospodarstwa krajowego, Lwów 1888.

Szkoły Rzeczypospolitej Polskiej w roku szkolnym 1930/31, red. M. Falski, Warszawa 1933.

Ślósarczyk J., Historia Pprowincji Św. Jacka Towarzystwa Salezjańskiego w Polsce, t. 1-7, Pogrzebień 1960-1969, mps.

Świda A., Droga do samodzielności polskiej prowincji salezjańskiej, Warszawa 1990. Świda A., Salezjańskie szkolnictwo w Polsce, w: 75 lat działalności salezjanów w Polsce, red. R. Popowski, S. Wilk, M. Lewko, Łódź-Kraków 1974, s. 37-58.

Swida A., Towarzystwo Salezjańskie, Kraków 1984.

Sw. Jan Bosko, Kraków 1938.

Św. Jan Bosko, Wspomnienia oratorium, Warszawa 1987.

Tarnowski S., Ks. Marcelina Czartoryska, "Przegląd Polski”, 29 (1895), s. 17-284.

Ustawy i Regulaminy Towarzystwa Sw. Franciszka Salezego, Warszawa 192.5.

Zgromadzenie Sióstr Matki Bożej Miłosierdzia 1862-1962, Józefów 1962 (mps).

\section{SPIS TREŚCI}

\section{Wstęp}

Rozdział I. Geneza, powstanie i losy schroniska. . . . . . . . . . . . . . . 445

1. Sytuacja w dziedzinie opieki i wychowania młodzieży w Krakowie

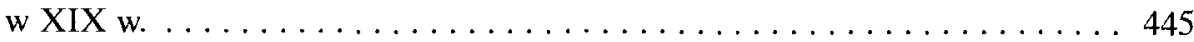

2. Początki funkcjonowania schroniska dla opuszczonej młodzieży. . . . . . . 452

3. Funkcjonowanie schroniska w latach 1914-1925, 1939-1945 . . . . . . . 455

4. Przejęcie schroniska przez władze PRL . . . . . . . . . . . . . . . . . 459

Rozdział II. Zarząd i personel schroniska . . . . . . . . . . . . . . . . . . . 464

1. Kierownictwo i personel schroniska. . . . . . . . . . . . . . . . . 464

a) pod zarządem diecezjalnym . . . . . . . . . . . . . . . 464

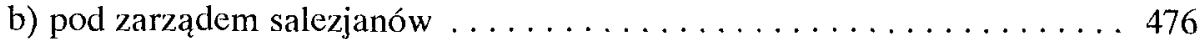

2. Kuratoria fundacji jako organ nadzoru schroniska . . . . . . . . . . . . 498

Rozdział III. Podstawy materialne . . . . . . . . . . . . . . . . . . 502

1. Kapitał fundacyjny . . . . . . . . . . . . . . . . . . . . . . . . . 502

2. Dochody zwyczajne i nadzwyczajne. . . . . . . . . . . . . . . . 507

Rozdział IV. Formy działalności wychowawczo-oświatowej . . . . . . . . 5 516

1. Towarzystwa o charakterze religijnym . . . . . . . . . . . . . 517

2. Towarzystwa i kółka zainteresowań . . . . . . . . . . . . . . 520 


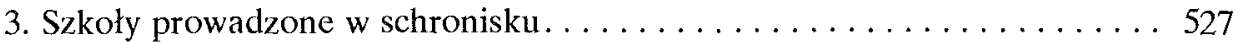

a) szkoła szewska . . . . . . . . . . . . . . . . . . . . . . . . . 529

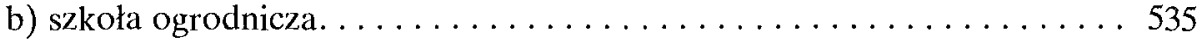

4. Oratorium salezjańskie. . . . . . . . . . . . . . . . . . . . 540

5. Organizacja Byłych Wychowanków Salezjańskich . . . . . . . . . . . . 544

Zakończenie . . . . . . . . . . . . . . . . . . . . . . . . . . . 549

Bibliografia . . . . . . . . . . . . . . . . . . . . . . 550 


\section{DIE HEIME DER FÜRST-ALEKSANDER-LUBOMIRSKI-STIFTUNG IN KRAKAU}

\section{ZUSAMMENFASSUNG}

Im 19. Jahrhundert konnte das übervölkerte galizische Dorf nicht mehr alle seine Bewohner ernähren. In der Hoffnung auf ein leichteres Leben gingen viele von ihnen in die Städte und vergrößerten damit nur die Reihen der städtischen Armen, bei denen das Schicksal der Kinder und Jugendlichen ebenfalls beklagenswert war. Mit diesem Problem beschäftigten sich karitative Einrichtungen und Privatpersonen. Der in Paris lebende Fürst Jerzy Aleksander Lubomirski (18021893) hatte am 31. August 1885 der Landeskammer in Lemberg 2 Millionen Franken für öffentliche und wissenschaftliche Zwecke vermacht. Die nach ihm benannte Stiftung genehmigte für 1893 in Krakau (ulica Rakowicka 27) den Bau eines Heims für Knaben sowie einer ähnlichen Anstalt für Mädchen, die 1889-1890 außerhalb der damaligen Krakauer Stadtgrenzen in Łagiewniki errichtet wurde.

Die vorliegende Arbeit behandelt „Die Heime der Fürst-Aleksander-Lubomirski-Stiftung in Krakau". Die neu erbaute Anstalt wurde am 4. November 1893 von Kardinal Albin Dunajewski geweiht. Ins Heim wurden Knaben aufgenommen, die das achte Lebensjahr vollendet und das fünfzehnte noch nicht erreicht hatten und die von ihren juristischen Vormündern, den Gerichts- oder Gemeindebehördèn angemeldet wurden. Hier sollten sie eine religiöse und sittliche Erziehung genieBen, eine Grundausbildung erhalten und berufliche Qualifikationen erwerben.

Die Leitung des Heims übernahm ein Diözesangeistlicher. Das für Erziehung und Unterricht zuständige Personal bestand aus Laien (für die älteren Zöglinge) und Barmherzigen Schwestern (für die jüngeren Knaben). 1911 übernahmen die Salesianer die Verwaltung des Heims.

Der erste Weltkrieg brachte für die Arbeit dieser Institution starke Einschränkungen mit sich. Ein Teil der Zöglinge wurde in andere Jugendheime der Salesianer geschickt. Außerdem verfiel infolge der Geldentwertung das „eiserne Kapital” in Millionenhöhe, das die Grundlage für den Unterhalt der Zöglinge bildete.

Erst im neuentstandenen polnischen Staat, am 17. Oktober 1925, wurden die Salesianer von den Stadtvätern wieder mit der Verwaltung des Heims betraut. Es hatte den Charakter eines Internats. In den darauffolgenden Jahren wurde hier eine Handwerks- und Industrieschule mit einer Gärtnerei- und einer Schuhmacherabteilung eingerichtet. Die Gärtnereiabteilung machte sich 1931 als Öffentliche Weiterbildungsschule für Gärtner selbständig. Die Schuhmacherabteilung war nie sehr 
populär, so daß die Direktion schließlich ihre Auflösung beschloß. 1939 verließen ihre letzten Absolventen die Schule.

Durch den Ausbruch des 2. Weltkrieges wurde die Arbeit dieses Jugendheims völlig lahmgelegt. Die Anstalt wurde von den deutschen Besatzern in Beschlag genommen. Für die meisten salesianischen Mitarbeiter begann ein kriegstypisches Wanderleben. Am Ort verblieb lediglich der Direktor, Alojzy Sękowski, mit einigen Mitbrüdern. Sie arbeiteten im Garten der Anstalt. Nur 10 Zöglingen konten bei den Karmeliterpatres untergebracht werden.

Nach dem 2. Weltkrieg, unter den veränderten politischen und gesellschaftlichen Bedingungen der Polnischen Volksrepublik, hörte das Heim 1950 nach 57-jährigem Wirken zu bestehen auf.

Aus dem Polnischen übersetzt von Herbert Ulrich 